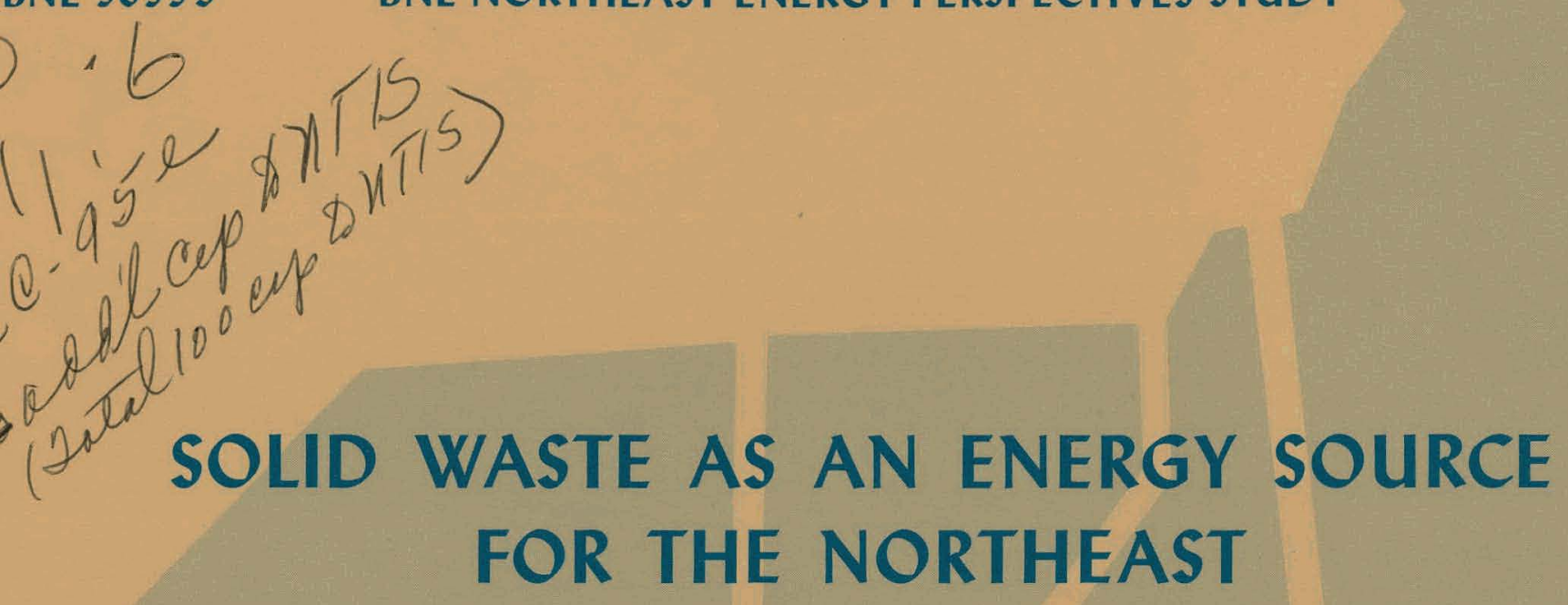

P.M. Meier and T.H. McCoy

June 1976

POLICY ANALYSIS DIVISION

NATIONAL CENTER FOR ANALYSIS OF ENERGY SYSTEMS BROOKHAVEN NATIONAL LABORATORY

UPTON, NEW YORK II 973

Prepared for the

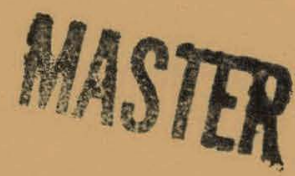

UNITED STATES ENERGY RESEARCH AND DEVELOPMENT ADMINISTRATION 


\section{DISCLAIMER}

This report was prepared as an account of work sponsored by an agency of the United States Government. Neither the United States Government nor any agency Thereof, nor any of their employees, makes any warranty, express or implied, or assumes any legal liability or responsibility for the accuracy, completeness, or usefulness of any information, apparatus, product, or process disclosed, or represents that its use would not infringe privately owned rights. Reference herein to any specific commercial product, process, or service by trade name, trademark, manufacturer, or otherwise does not necessarily constitute or imply its endorsement, recommendation, or favoring by the United States Government or any agency thereof. The views and opinions of authors expressed herein do not necessarily state or reflect those of the United States Government or any agency thereof. 


\section{DISCLAIMER}

Portions of this document may be illegible in electronic image products. Images are produced from the best available original document. 


\title{
SOLID WASTE AS AN ENERGY SOURCE FOR THE NORTHEAST
}

\author{
P.M. MeIer ANd T.H. MCCOY
}

June 1976

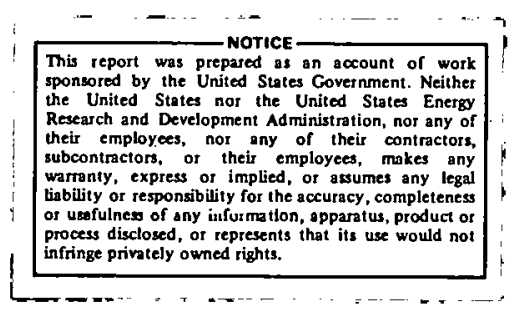

Work supported by the Division of Biomedical and Environmental Research of the United States Energy Research and Development Administration urirder Contract No. E(30-1)-16 in the context of the Brookhaven National Laboratory Regional Energy Studies Program. 


\section{NOTICE}

This report was prepared as an account of work sponsored by the United States Grvernmont. Neither the United States nor the United States Energy Research and Development Administration, nor any of their employees, nor any of their contractors, subcontractors, or their employees, makes any warranty, express or implied, or assumes any legal liability or responsibility for the accuracy, completeness or usefulness of any information, apparatus, product or process disclosed, or represents that its use would not infringe privately owned rights.

Printed in the United States of America

$$
\text { Available from }
$$

National Technical Information Service

U.S. Dcpartment of Commerse 5285 Port Royal Road Springfield, VA 22161

Price: Printed Copy \$7.50; Microfiche $\$ 2.25$ 
FOREWORD

This report is one of a number of issue papers prepared as part of the Brookhaven National Laboratory Northeast Energy Perspectives Study. The analyses in these papers were performed specifically to assist us in our first integrated study of the energy future of the northeastern United States.

Topics covered by the issue papers include the potential supply of energy to the Northeast from coal, oil, natural gas, liquefied natural gas (LNG), nuclear power, municipal waste, solar energy, and wind power, and the demand for energy in the Northeast from the industrial, transportation, and residential and commercial sectors. In each case a range of estimates of energy supply or demand was constructed to reflect not only a variety of possible policy and technological developments, but also the basic uncertainties of all such future projections. The integrative analysis which relates the supply and demand picture is presented in "A Perspective on the Energy Future of the Northeast United States."

The issue papers prepared for the Northeast Energy Perspectives study and the summary report will be available from:

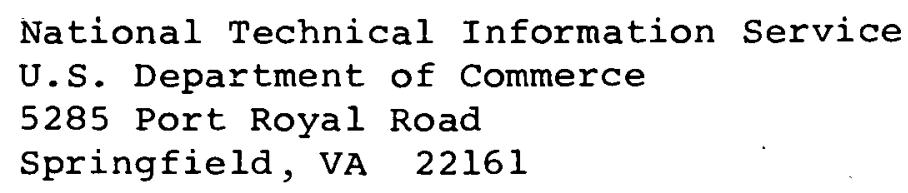

The issue papers and summary report are listed below. 
H. Bronheim, "Future Oil Supply to the Northeast United States," BNL 50557 (June 1976).

R. J. Goettle, IV, "Alternative Patterns of Industrial Energy Consumption in the Northeast," BNL 50555 (March 1976).

R. N. Langlois, "Future Natural Gas Supply to the Northeast," BNL 50558 (April 1976).

J. Lee, "Future Residential and Commercial Energy Demand in the Northeast," BNL 50552 (March 1976).

P. M. Meier and T. H. McCoy, "Solid Waste as an Energy Source for the Northeast," BNL 50559 (June 1976).

P. M. Meier, T. H. McCoy, and S. Rahman, "Issues in the Future Supply of Electricity to the Northeast," BNL 50553. (June 1976).

B. S. Edelston and E. S. Rubin, "Current and Future Use of Coal in the Northease," BlNL 30560 (May 197G), Eirvironmental

Studies Institute, Carnegie-Mellon University, Pittsburgh, Penn.

V. L. Sailor and F. J. Shore, "The Future of Nuclear power in the Northeast," BNL 50551 (March 1976).

G. R. Bray, S. K. Julin and J. A. Simmons, "Supply cf Liquefied Natural Gas to the Northeast," BNL 50556 (April 1976), Science Applications, Inc., 1651 old Meadow Road, Mctean, Va.

System Design Concepts, Inc., "Transportation Energy Consumption and Conservation Policy Options in the Northeast," BNL 50554 (April 1976), System Design Concepts, Inc., 9 Rector Street, Now York, N.Y. 10006 .

J. Brainard et al., Editors, "A Perspective on the Energy Future of the Northeast United States," BNL 50550 (June 1976). 


\section{ABSTRACT}

This report, one of a series prepared for the BNL study of the Energy Future of the Northeastern United States, presents an assessment of the potential contribution of energy recovery from municipal refuse to energy supply in the region. A brief review of the present and likely future quantity and composition of municipal refuse and the technologies available for energy recovery (Chapters II and III) is followed by a comparison of the potential contributions to energy supply of the various recovery options including direct firing in utility boilers, pyrolysis to oil or gas, and steam generation for industrial process heat or district space heating (Chapter IV). The relationship of refuse energy recovery to market conditions for alternative energy sources is considered in Chapter $\mathrm{V}$, which also includes an analysis of the impact of haul costs, interest rates, and delivered prices of the major fuels. Institutional barriers to implementation of energy recovery are reviewed in Chapter VI, and the environmental implications of the concept are addressed in chapter VII. In the concluding chapters scenarios of energy recovery are developed for 1985 and 2000 , and the sensitivity of overall energy yield to projections and assumptions is examined.

Although even under the most optimistic assumptions, refuse energy recovery is found to contribute only some $5 \%$ of total regional consumption, the economic and environmental benefits, coupled with the increasing difficulty of finding other refuse disposal alternatives, make energy recovery a very attractive policy choice for helping to relieve future energy supply difficulties in the Northeast. 
TABLE OF CONTENTS

Abstract

I. Introduction . . . . . . . . . . . . . . . . . . . 1

II. Quantities and composition of Refuse

2.1. Quantities of Refuse . . . . . . . . . .

2.2 Refuse Composition . . . . . . . . . . .

III. The Options for Energy Recovery

3.1 Combustion in Electric Utility Boilers . . . . 23

3.2 Bioconversion . . . . . . . . . . . . . 29

3.3 Pyrolysis . . . . . . . . . . . . . . 30

3.4 Steam Generation. . . . . . . . . . . . 35

3.5 Other Options . . . . . . . . . . . . . 37

IV. The Potential Energy Yield

4.1 Combustion. . . . . . . . . . . . . . 43

4.2 Bioconversion . . . . . . . . . . . . . . 46

4.3 Pyrolysis. . . . . . . . . . . . . . . 47

4.4 Steam Generation. . . . . . . . . . . . 48

4.5 Comparative Assessment. . . . . . . . . . 49

V. Economic Analysis

5.1 A Framework for Analysis. . . . . . . . . . 55

5.2 Breakeven Prices for Refuse Fuel. . . . . . 59

5.3 Process Comparisons . . . . . . . . . . 73

5.4 Haul Costs. . . . . . . . . . . . . . 76

5.5 Results for Northeastern SMSA's...... . . 81

5.6 A Caveat . . . . . . . . . . . . 87

VI. Institutional Conotrainto. . . . . . . . . . . . . . . . . 91

VII. Secondary effects

7.1 Environmental Ramifications . . . . . . . 101

7.2 Relationship to Materials Recovery Options • • 104

VIII. Sensitivity Analysis

8.1 Sensitivity to Per Capita Refuse Generation . . 109

8.2 Sensitivity to Population Density Gradient

Assumptinns . . . . . . . . . . . . 111

8.3 Sensitivity to Refuse Composition Assumptions . 112 
x. Scenarios

9.1 Introduction . . . . . . . . . . . . 119

9.2 Low Case . . . . . . . . . . . . . . 119

9.3 High Case. . . . . . . . . . . . . . . 123

9.4 Contribution . . . . . . . . . . . . . 124

X. Summary and Conclusions . . . . . . . . . . . 127 Appendix

A. Energy Yield from Combustion. . . . . . . . . 129

B. Derivation of Solid Waste Generation Equations. . . . 133

C. Derivation of Haul Cost Equations . . . . . . . . 136

D. Determination of the Optimal Delivery Distance to an Energy Recovery Facility . . . . . . . . 145

E. Fossil-Fueled Utility Boilers in the Northeast. . . . 147

F. Descriptions of Energy from Refuse Projects in the

Northeast. . . . . . . . . . . . 155

G. Bibliography. . . . . . . . . . . 181 


\section{CHAPTER I}

\section{INTRODUCTION}

The problems of solid waste management have become increasingly severe over the past decade, but especially so in the densely populated metropolitan areas of the country, where the increasing difficulty of finding landfill sites, the restriction of incineration by implementation of air quality standards and the ever growing militance of sanitation labor unions have combined to make solid waste management not only more and more expensive, but, in many cases, an almost intractable political issue. In rural areas the situation is little better, as the cost of turning the traditional town dumps into properly operated sanitary landfills appears to face increasing resistance from property tax payers long accustomed to what is perceived as "free" solid waste disposal.

Under these conditions one might expect the climate for resource recovery to be rather favorable. Yet the Nation's experience with resource recovery from solid waste has, until only very recently, been uniformly disappointing. Chemical fertilizer has been so cheap in the U.S. that a substantial commercial market for compost, which determines the feasibility of composting plants, has simply not materialized. ${ }^{1}$ Efforts at incineration of solid waste in waterwall boilers to recover the energy in the form of steam have similarly proven unsuccessful; ${ }^{2}$ in part because of the lack of market for the resulting steam (due, historically, of course, to the very cheap cost of alternative energy supplies for both domestic heating and industrial process heat) and in part because of the difficulty of efficient combusion of refuse (which has.also resulted in the failure of most 
municipal refuse incinerators, especially with the imposition of air quality standards that almost double costs ${ }^{3}$ ).

Efforts at recovery of materials from municipal refuse have suffered a similar fate. Until very recently, separation of the components of mixed refuse was performed by hand, an increasingly costly and inefficient operation. But even with the development of sophisticated separation technology, exemplified by the development of air classification separation of the combustible fraction of refuse from the heavier, noncombustible fraction, resource recovery has been market Iimited. 4 For a variety of reasons, the use of recovered materials from solid waste has been either uneconomic, ${ }^{5}$ or prohibited outright on grounds of public health; 6 and thus resource recovery has proved successful only under special market circumstances. The most successful such operation is the fiber reclamation plant at Franklin, Ohio; but the recovered product is a rather low-grade fiber used in a nearby roofing felt plant. 7

In the late $1960^{\prime}$ s the, idea of using refuse as a supplementary fuel in utility boilers began to surface, and the results of an early demonstration project in st. Louis appeared very encouraging. 8 The burning of refuse in highly efficient utility boilers bypasses the intractable problems of municipal incinerators, provides fuel savings for the utilities, and solves problems of marketing and distribution of the recovered energy.

Until the advent of the 1973 oil embargo, however, even this most promising resource recovery option was not persued with any enthusiasm. The main issue appeared to be the apportionment of the savings; the utilities were prone to argue that since they were taking over the function of solid waste disposal, and thereby saving the municipality $\$ 5$ to $\$ 20$ per ton in disposal cost, they 
should at least be given the solid waste free of charge, if not paid a disposal fee. The municipalities argued that they were in fact selling a fuel, and should be paid for it on the basis of Btu equivalent, just as utilities pay coal suppliers for that fuel. From the utilities viewpoint, there was the additional problem of making modifications to the generating facility, including the provision of storage and size reduction facilities, as well as the modification of the boilers and burners themselves.

Since the advent of the oil embargo, however, the significant increases in energy costs to the utilities have changed the situation somewhat. Since coal prices have climbed sharply, the value of refuse has risen also; and equitable compromises are perhaps easier to find. The recovery of metals from refuse, particularly aluminum, has also become more worthwhile. 9 over the past three years, many Northeastern states have now moved forward with statewide solid waste management plans focused on energy and resource recovery. 10 Moreover, many utilities and municipalities are currently pursuing with renewed vigor the possibility of burning refuse in boilers, and within the next decade this concept will doubtless be implemented as a permanent feature of solid waste management and energy supply.

This report, then, presents an analysis of the potential contribution of solid waste as an energy source in the Northeastern United States. Discussion of the recovery of materials from solid waste is limited to an analysis of the trade-offs between material and energy recovery, although the importance of metals recovery is recognized in view of the current world political climate and the high probability that suppliers of commodities, and especially suppliers of metal ores, will succeed in organizing cartels similar to OPEC. ${ }^{11}$ It will be seen, however, that recovery of 
metals from refuse is little affected by energy recovery.

Besides the option of burning municipal refuse in utility boilers, we shall also consider the other important energy recovery options, which, although not currently regarded as proven concepts, appear to be on the verge of commercial feasibility (Figure 1). Thus, we shall also assess pyrolysis of refuse to yield either gas or a mix of liquid hydrocarbons; bioconversion. by anaerobic microbial decomposition. of the organic fraction to yield methane; $^{12}$ and combustion for steam generation using newly developed European technology. Low Btu gas hyarogasificatiun and Brayton cycle power generation are also briefly reviewed. ${ }^{13}$

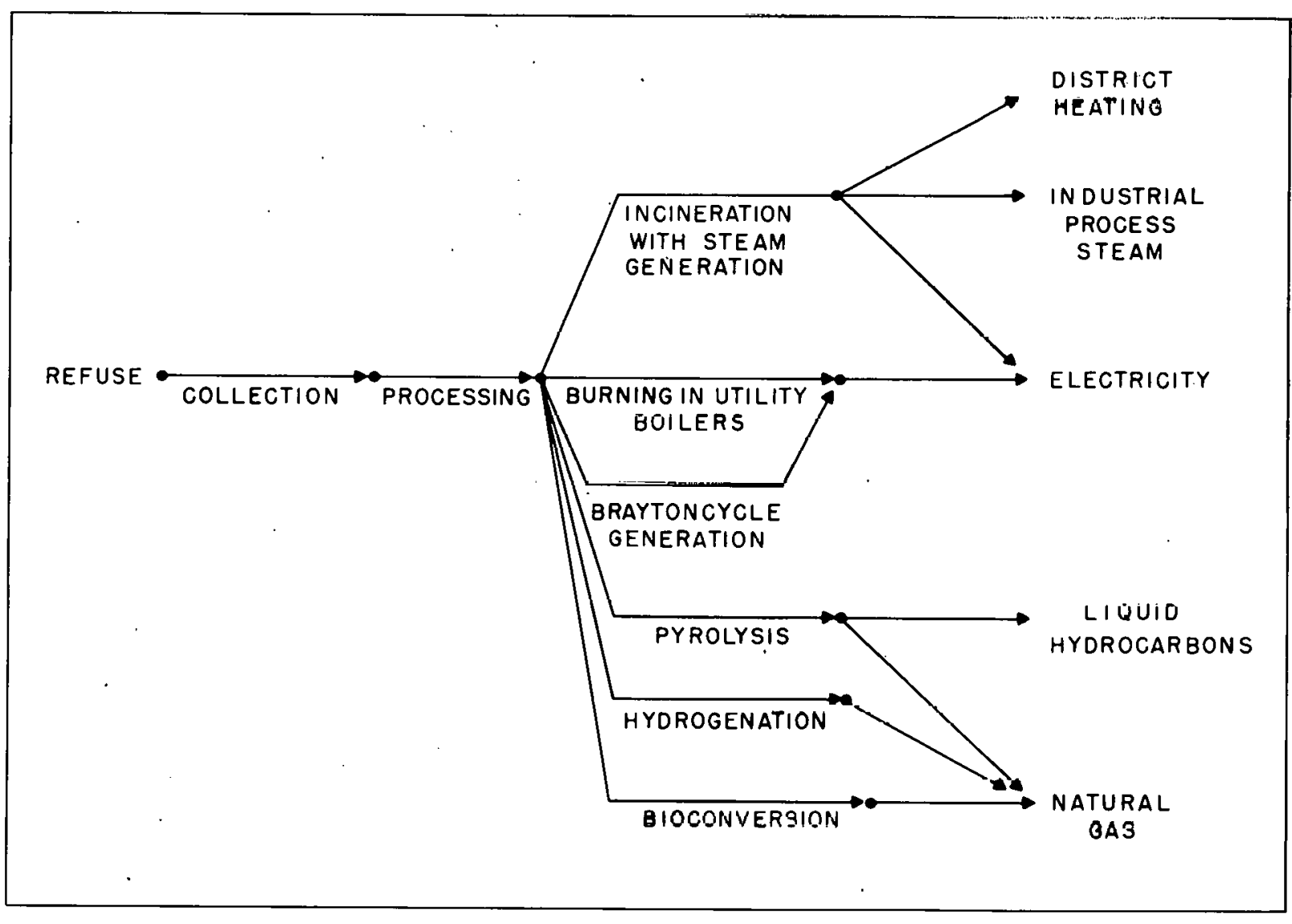

Figure 1. Options for energy recovery from solid waste. 
1. Currently only two plants, one in Altoona, Pa., and the other in Brooklyn, N.Y., are known to be operating in the U.S. on a regular basis. The most celebrated failure is the plant built in Johnson City, Tenn., by the U.S. Public Health Service and TVA, which began operation in 1967 as a demonstration of the potential for composting. Apart from operational problems, the lack of a nearby market for the plant product led to the inevitable abandonment of the project. Note, however, that the European experience with composting has been altogether different, and largely successful. High population densities, smaller transportation distances and hence lower transportation costs, and the relatively higher cost of synthetic chemical fertilizer have resulted in a commercially exploitable market for compost.

2. For a review of the United States experience and the major facilities now operating, see e.g. "Resource Recovery: The State of Technology" Report by the Midwest Research Institute to $C E Q$, February 1973. One might again note that the European experience is again much more successful, and water-wall furnace technology has been developed in Germany and Switzerland. The advantage of waterwall furnaces over the conventional refractory furnaces in use in U.S. incinerators lies in the higher heat transfer efficiency, which results in lower excess air requirements and hence fewer air pollution problems (for further elaboration, see e.g. Drobny N.L. et al. "Recovery and Utilization of Municipal Solid Waste". U.S. Environmental Protection Agency, 1971, Report SW-10c.)

3. For a discussion of the problems of municipal incinerators from an air pollution standpoint, see e.g. A.G. Carotti and R.A. Smith, "Gaseous Emissions from Municipal Incinerators", U.S. Environmental Protection Agency, 1974, Report SW-18c.

4. The most comprehensive survey of the salvage markets for recovered materials from refuse is A. Darney and W.E. Franklin, "Salvage Markets for Materials in Solid Wastes", U.S. Environmental Protection Agency, 1972, Report SW-29c.

5. Interstate freight rates, for example, are lower for virgin than for recycled materials in almost all categories potentially recoverable from solid waste, a situation which significantly affects the economic competitiveness of recycled 
products. Together with some institutional distortions, such as the depletion allowances available to mineral producers, this has historically made markets in recovered materials extremely limited.

6. Many public health regulations impose severe restrictions on fiber recycling; paperboard for food cartons, for example, especially for milk and other liquid foods, must be made of virgin fiber or clean scrap from the manufacturing process.

7. For a description and evaluation of this facility, see, e.g. N.T. Neff, "Solid Waste and Fiber Recovery Demonstration Plant for the City of Franklin, Ohio: An Interim Report", U.S. Environmental Protection Agency, Report SW-45d, 1972 (Published by NTIS, PB. 213646 ).

8. See e.g. Horner and Shifrin, Inc., "Solid Waste as a Fuel for Power Plants", Report to EPA, 1973 (Published by NTIS, PB 220 316).

9. Aluminum is one of the few metals for which the economics have traditionally favored secondary rather than primary sources. The production of primary aluminum requires high capital investments $(\$ 700$ to $\$ 800$ per ton of annual capicity) and large amounts of electric power, $(15,000$ to $16,000 \mathrm{kwh}$ per ton of aluminum). Consequently, such smelters tend to be located near sources of low cost electricity; but these are usually remote from industrial centers, and, therefore, primary aluminum producers have high freight costs, ( $\$ 5$ to $\$ 30$ per ton). Primary aluminum production costs, including freight to fabricators, range from $\$ 306$ to $\$ 470$ per ton. In contrast, secondary smelters can install capacity for $\$ 100-\$ 120$ per ton and can be located near scrap sources that are nearer the points of consumption, which in turn means lower freight costs. Operating costs are also cheaper because the major operation is scrap melting rather than electrolytic reduction of aluminum ores to aluminum. Secondary smelter total production costs range from $\$ 375$ to $\$ 450$ per ton. With the recent rises in electrical energy costs, and the higher world market price for bauxite, the advantage of secondary aluminum is becoming even greater. For further discussion, see Darnay and Franklin, note 4 , supra, Chapter VI.

10. See e.g., "A Systems Evaluation of Alternate Statewide Resource Recovery Techniques for the disposal of Municipal Solid Waste", Report by A.D. Little to the Massachusetts Department of Public Works, December 1973 or "State of Vermont Agency of Environmental Conservation Agency - Solid Waste Mangement and 
Resource Recovery Plan", January 1973 (Published by NTIS, PB 235 219).

11. See e.g., B. Varon and K. Takeuchi, "Developing Countries and Non-fuel Minerals", Foreign Affairs, Vol. 52, No. 3, p. 511 (April 1974), who conclude that Bauxite and Phosphate producers face the most favorable conditions for market manipulations by means of producer's cartels.

12. We shall refer to this process by the traditional, and somewhat less cumbersome, "anaerobic digestion".

13. For information on other options still in the conceptual study phase, section 6 of the Bibliography (Appendix G) contains some selected references. Possibilities include acid hydrolysis of cellulose to produce ethyl alcohol, enzymatic conversion to glucose, or conversion to Yeast. 


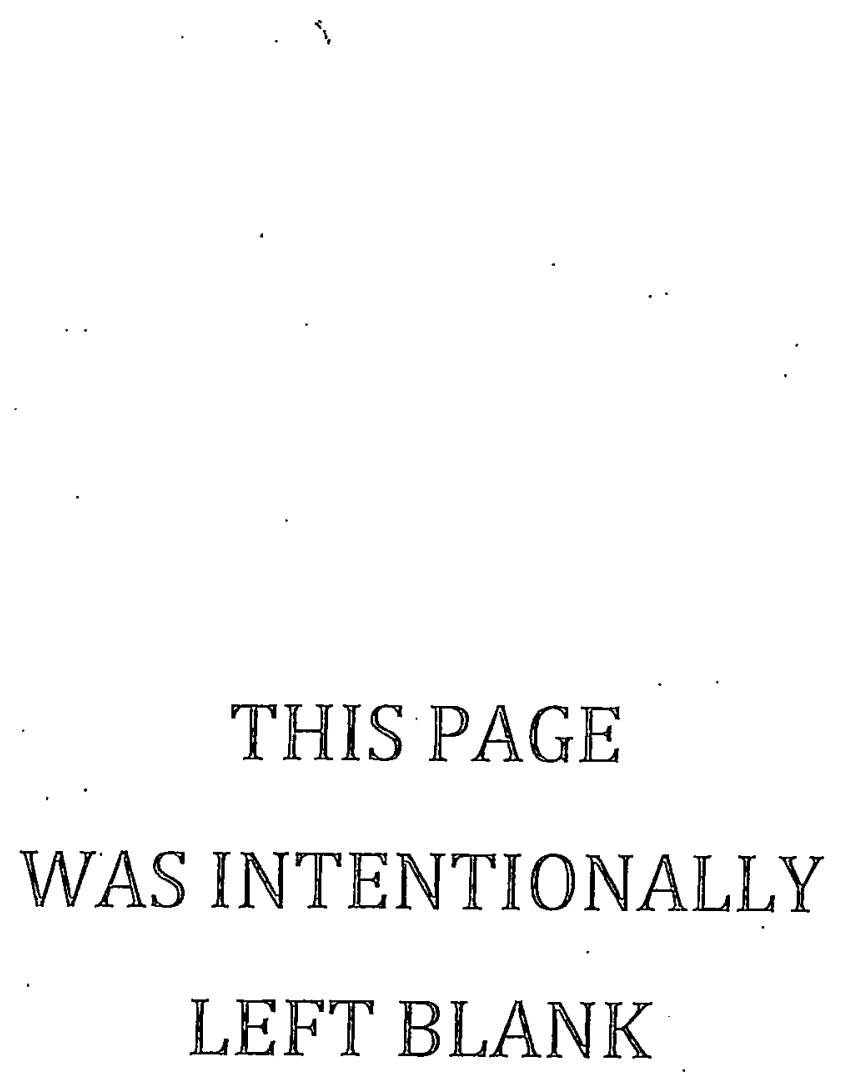


CHAPTER II

QUANTITIES AND COMPOSITION OF REFUSE

\subsection{Quantities of Refuse}

Modern society generates numerous categories of waste materials that have a significant content of organic matter, and therefore, offer some potential for energy recovery. The main categories, as noted by Anderson, ${ }^{1}$ are animal manure, agricultural crop wastes, urban refuse, logging and wood manufacturing residues, sewage sludge solids, and industrial wastes. Table 1 gives some indication of the relative amounts involved in the United States:

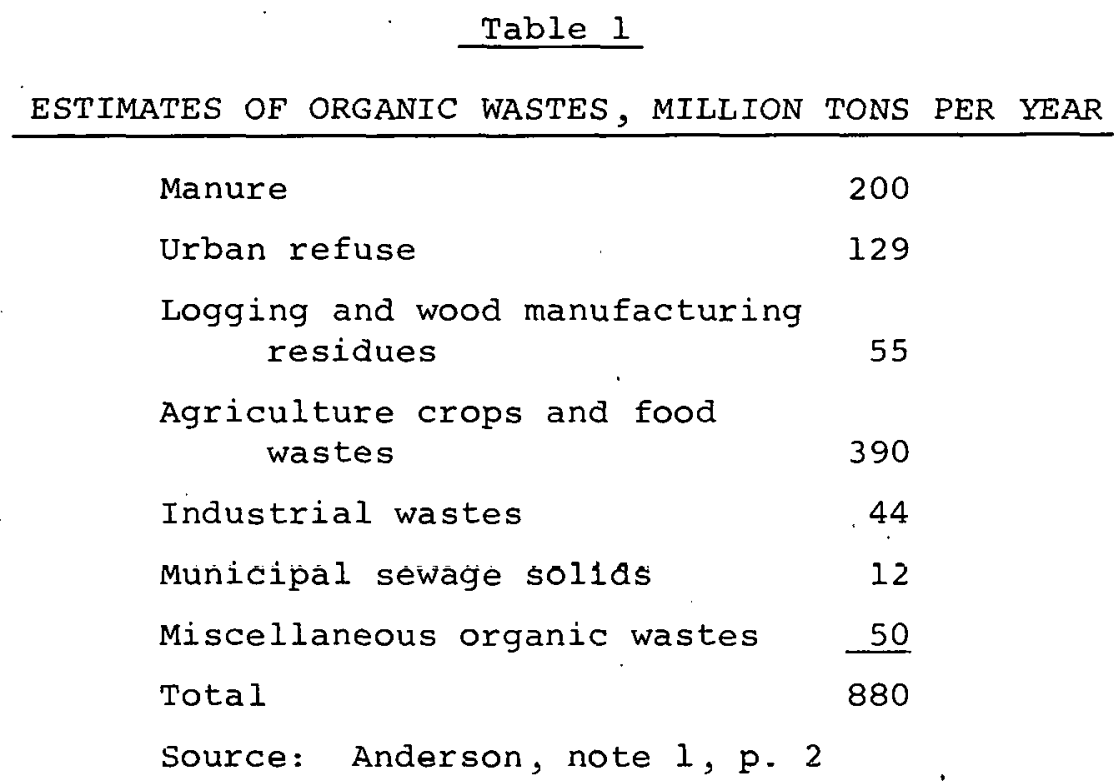

Not all these categories are of interest as energy sources to the Northeast, and the present discussion is restricted to urban refuse and municipal sewage solids. Agricultural wastes and manure are generated primarily in the Midwest, and energy 
recovery from agricultural wastes appears to be justified only in such areas of the U.S. where agriculture is organized in relatively large, consolidated units. ${ }^{2}$ Although the recovery of energy on an individual farm basis in the Northeast is not precluded, agricultural wastes appear unsuited as a source of energy for the major energy consuming urban areas in the region. The paucity of information on industrial wastes justifies exclusion of that category from this analysis. However, the logging and wood manufacturing residue category does appear to be of interest to the Northern New England states, and is omitted here only because of the limited information on this subject at the time of writing. 3

The organic waste listed under urban refuse in Table 1 is only a small fraction of the total urban refuse qenerated. The most frequently cited figure for total urban refuse generation is 5.72 pounds per capita per day, a figure derived in the first nationwide survey of solid waste problems in 1968. 4 However, this total includes street sweepings, demolition and construction wastes, and some industrial wastes; in fact, the 1968 survey figure for residential and commercial refuse alone is 4.35 1.b/cap/ day. But even this latter figure has been critized as being far too high. 5 This 1968 survey relied on municipalities themselves to furnish quantitative estimates, yet in many cases these were speculations rather than measured facts, as historically there was little interest in expenditure for weighing and sampling refuse.

The problem of data in the solid waste field is formidable, and there is no comprehensive national or regional survey of adequate detail and reliability. To be sure, numerous studies and estimates exist for individual towns and cities, but quantitative comparisons are made difficult by the significant variations in reporting quidelines. For an estimate of solid waste generation 
=o be acceptable, it must include specific information about the following items, among others: the extent of garbage grinding in homes; whether bulky wastes are collected separately and whether they are included in the total; what fraction of commercial refuse is included in the total; and whether, if garbage is collected separately, it is included in the total (frequently it is not because its collection is privately contracted for delivery to piggeries, especially in the Northeast). ${ }^{6}$

Recognizing the inadequacies of the existing solid waste data base, the U.S. Environmental Protection Agency (EPA) commenced in 1973 a systematic, scientific data collection effort for a stratified random sample of Standard Metropolitan Statistical Areas (SMSA), the intent being to create a national data resource on solid waste quantities, composition, collection, and disposal costs. ${ }^{7}$ Unfortunately, this program has had its funding difficulties, and the fruits of the data collection effort are not yet apparent. However, preliminary data for the initial years of the program are available in unpublished EPA reports, and these data would appear to be the most reliable in existence. 8

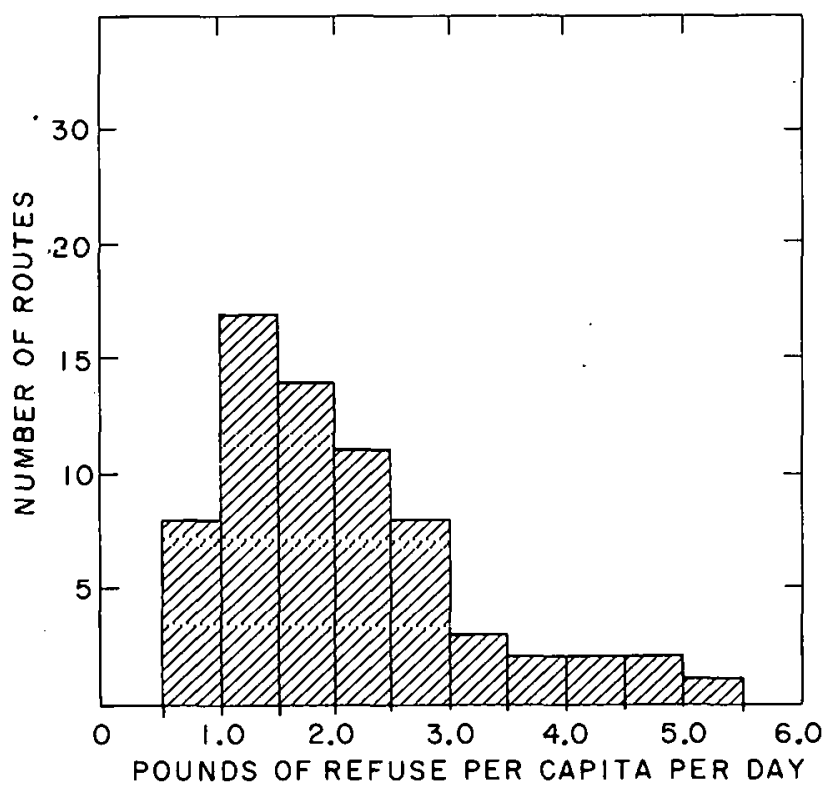

Figure 2. Residential refuse generation rates (fruil Meier, note 5, p. 29). 
Figure 2 shows the 1973 distribution of per capita refuse generation rates in a sample of SMSA's included within this EPA Program; a representative average value might be around $2.25 \mathrm{lb} /$ cap/day. 9 Unfortunately, the number of Northeastern SMSA's in the EPA sample is insufficient as a basis for a region-wide model, and information on per capita refuse generation was, therefore, assembled from a number of other sources. The regression analysis results shown on Table 2 show the refuse generation equation derived on the basis of the 19 SMSA-wide data sources that could be found; variables such as per capita income and population density were included so that the equation could be used to predict future refuse generation, since future per capita income and population projections are available from the OBERS projections that are the basis for the entire BNL Energy Futures study. ${ }^{10}$ Table 3 shows the results of this model when applied to all SMSA's in the region for 1972, 1985, and 2000, but excluding industrial wastes (i.e. $\mathrm{x}_{2}=0$ ).

\section{Table 2}

\section{REGRESSION EQUATION FOR REFUSE GENERATION}

\section{Variables}

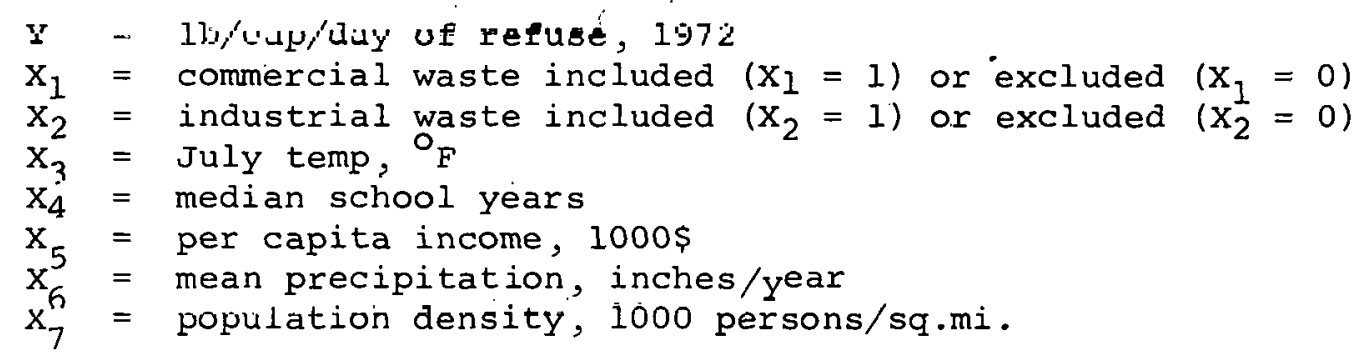

Regression Equation

$$
\begin{gathered}
Y=15.41+1.63 X+1.31 x_{2} \quad n .141 x_{3} \\
t=3.43 \quad t=2.75 \quad t=-1.87 \\
-0.247 x_{4}+0.42 x_{5}-0.055 x_{6}-0.29 x_{7} \\
t=1.515 \quad t=1.08 \quad t=-0.94 \quad t=-0.864 \\
\left(R^{2}=0.94\right)
\end{gathered}
$$


These figures exclude street sweepings, and demolition and construction wastes, and only that fraction of commercial refuse normally picked up by municipal collection is included. This presents some problems, because cities vary widely in the degree to which they collect commercial refuse. In some, municipal crews collect all refuse as a matter of policy; in others, there are special commercial collections by city-owned trucks; and in yet others, commercial refuse is picked up under separate private contract. Indeed, all three options may coexist. ${ }^{\text {Il }}$ The figure exciudes bulky wastes; these are domestic wastes not normaily picked up by the collection crews for reasons of bulk or weight, and for which many cities organize special pick-up arrangements. 12 These bulky items are typically discarded domestic appliances, furniture, old car batteries and tires, house remodeling debris or even unusually large amounts of domestic debris (sometimes referred to as "attic wastes").

Finally, one should note that we make no allowance for seasonal variation in this analysis. This, again, is not because we believe seasonal variation to be unimportant, but because available estimates are so sketchy that no statistically meaningful quantitative relationships could be derived for incorporation into a regional-scale analysis.

The 1985 and 2000 results in Table 3 lie in the high range of current generation rate projections. One recent study on the use of refuse for power generation from the national perspective noted that the increase in per capita consumption of non-durable goods between 1950 and 1967 was 1.5 percent per year; ${ }^{13}$ applying this growth rate to our 1972 estimate results in generation rates of 4 to $5 \mathrm{lb} / \mathrm{cap} /$ day by 1985 , and 5 to $6 \mathrm{lb} / \mathrm{cap} /$ day by 2000 , substantially below the Table 3 estimates. Some planners :xpect no future increase in per capita refuse generation levels, 
justified on the basis of a recent levelling off in generation rate in some cities, the likely impact of legislation banning noreturn beverage containers or changing current wasteful packaging practices, and an increasing tendency to separate types of refuse at the source.

Therefore, the regression equation of Table 2 is used below for a high estimate of future refuse generation; growth at $1.5 \% / y r$. is used to calculate the median; and zero growth is assumed for the low estimate. Unless otherwise stated, the median estimate is used in the following sections and the impact of high and low estimates on overall energy yield is referred to Chapter VIII.

\subsection{Refuse Composition}

Predictions of refuse composition are probably even more speculative than projections of total amounts. 14 It could be argued that each component should be individually projected to avoid separate specification of total amount and of fractional composition, the procedure adopted here. Unfortunately, independent quantitative projection of refuse categories is very difficult and can be done only for a few well-defined categories with reasonably reliable historical data. Thus, even if one or two categories are independently forecast, a total refuse projection still has to be made, with categories lacking independent projections obtained simply by difference.

In our judgement, the validity of the component projection equations in the literature is questionable. In particular, simple extrapolation of recent trends over long periods results in an unlikely mix of components. The nationwide paper content in municipal refuse, for example, has risen over the last decade from about $35 \%$ to $45 \%$, and mere linear extrapolation of this trend leads to quite unrealistic results. Logistic and s-type 


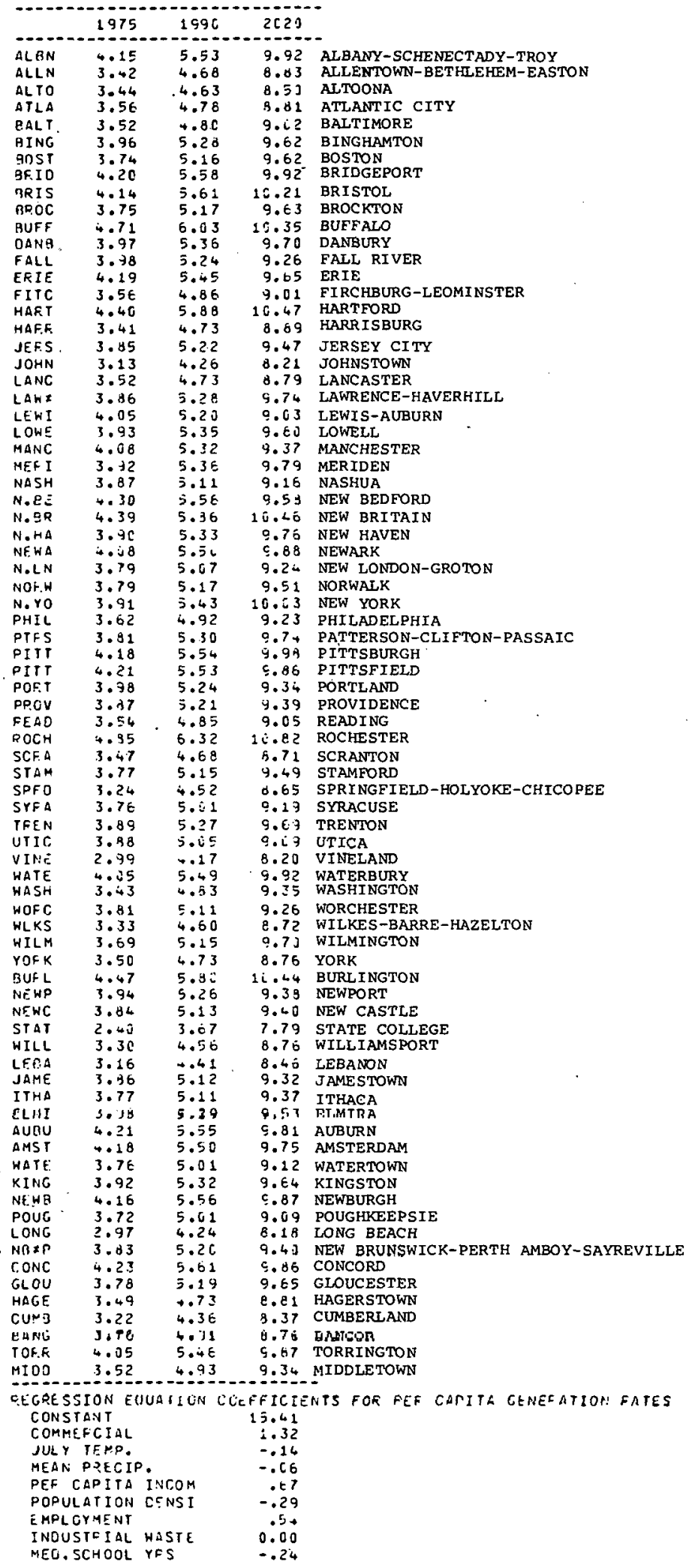


curves have been suggested to cope with this problem, but the point at which such a mathematical function levels off is quite arbitrary, and depends largely on each forecaster's choice. 15

The difficulties of prediction are compounded by legislative constraints. Assumptions regarding glass and metal are strongly influenced by restriction or elimination of non-returnable beverage containers. ${ }^{16}$ The experience of the last decade suggests that such legislation is most likely in the most environmentally conscious states, but predictions based on this are speculative, at best. Similarly, estimates of organic refuse, particularly kitchen wastes, on the extent of garbage grinders; some cities presently ban grinders for reasons of inadequacies in sewage treatment facilities, whereas others mandate them in new construction. Yet, it energy recovery from the organic fraction of refuse becomes successful, garbage grinders may even be banned in order to maximize energy yields and lessen loads on sewage treatment facilities.

Figures 3 and 4 show typical judgemental forecasts of refuse composition. 17 The significant differences between the two cities shown demonstrate the large variations encountered in refuse composition.

In view of the difficulties of making composition forectasts for each major metropolitan area in the Northeast, we shall use the composition forecast shown in Table 4, hased on the widely quoted study by Niessen and Chamsky. ${ }^{18}$ The sensitivity of the solution to changes in the assumed compnsition mix will be established in Chapter VIII. 19

The moisture content of refuse has special significance in energy recovery by combustion; and we have, therefore, chosen to specify it separately. Moisture content varies widely not only 


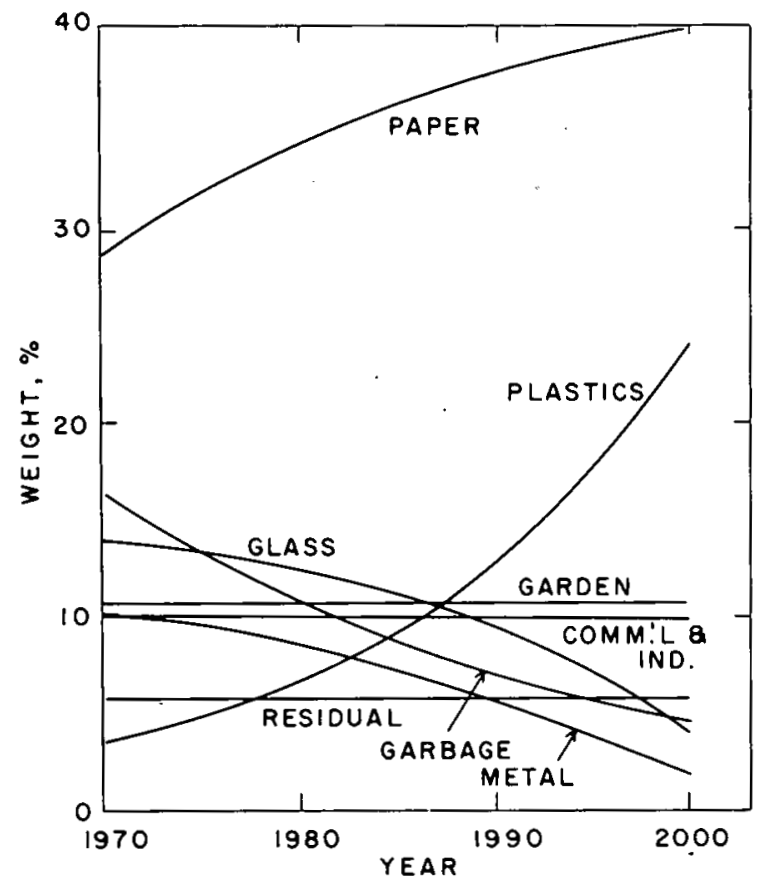

Figure 3. Projected compositional changes in Cleveland refuse (from Hanson, note 17, p. III-9).

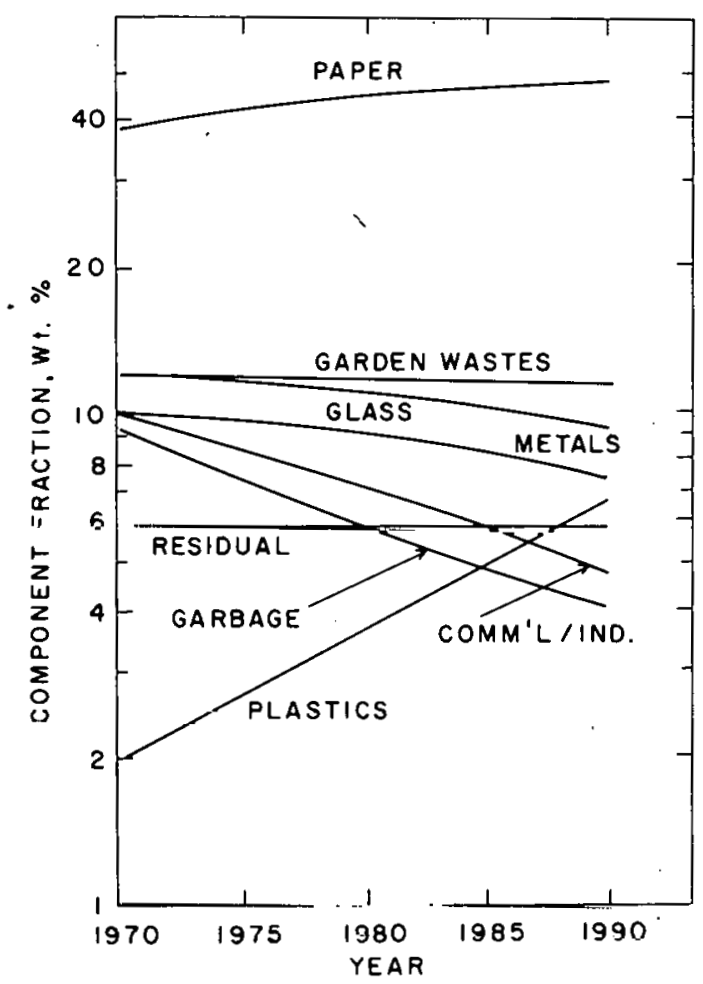

Figure 4. Projected compositional changes in Philadelphia refuse (from Hanson, note 17, p. II-10). 
Table 4

REFUSE COMPOSITION ASSUMPTIONS, BASE CASE

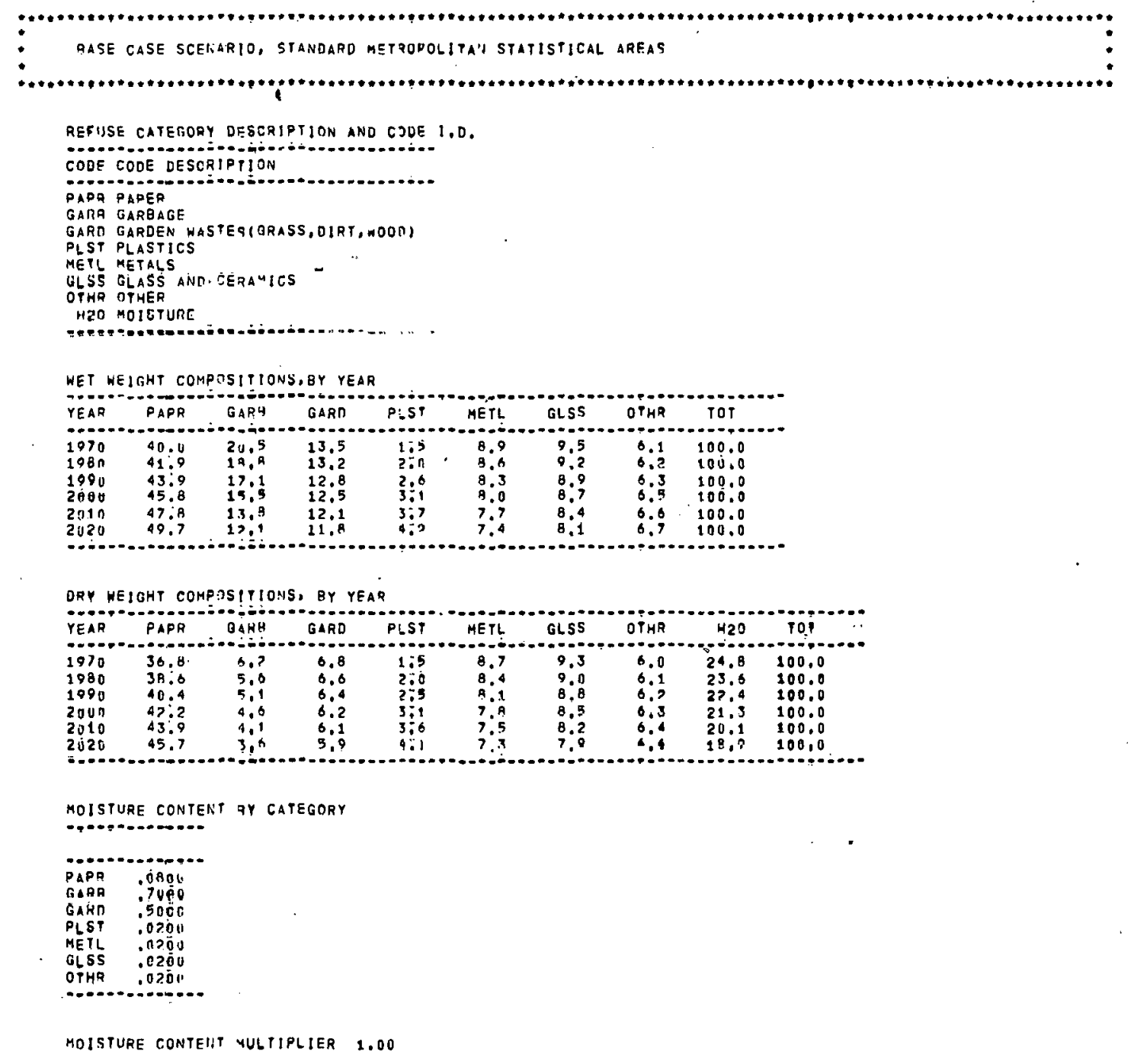


for reasons of variations in composition (refuse containing a high fraction of garden wastes, leaves, grass cuttings, and so forth, will obviously show a relatively high moisture content), but also with the weather - during periods of rainy weather moisture content rises significantly, due to the improper manner in which much urban refuse is stored awaiting collection.

The computer program used for making our computations, thus, makes two moisture content calculations. The first derives aggregate moisture content from the normal moisture content of each of the constituent components, as indicated on Table $4 .^{20}$ The second step adjusts for weather conditions using a simple multiplier of total moisture content - assumed in the base case computations to be equal to unity. 
1. L.L. Anderson, "Energy Potential from Organic Wastes: Review of the Quantities and Sources", U.S. Bureau of Mines, Information Circular 8549, 1972 (Published by NTIS, PB 211 249).

2. Indeed, there seems to be some question as to whether energy recovery from even the largest commercial agricultural operations is a feasible proposition. See e.g., L.A. Schmid, "Feedlot Wastes to Useful Energy-Fact or Friction", Journal, Environmental Engineering Division, American Society of Civil Engineers, Vol. 101, No. EE5, October 1975.

3. Indeed, not only are wood and lumber wastes of interest to the Northern New England states, but the use of wood itself as a primary fuel for electricity generation is being considered. An evaluation of wood as an energy source in the Northeast is currently under study by the BNL Regional Energy Studies Program.

4. "The National Solid Wastes Survey", U.S. Department of Health, Education, and Welfare, Public Health Service, 1968.

5. For a discussion on this point, and some examples of studies that relied on the $5.72 \mathrm{lb} / \mathrm{cap} /$ day figure and whose conclusions were, therefore, suspect, see e.g., P. Meier, J. Kuhner, and C. Martel, "A Preliminary Assessment of wet systems for Residential Refuse Collection", U.S. Environmental Protection Agency, March 1974 (Published by NIIS, PB 234 496).

6. This is the case, for example, in the city of springfield, Mass. One might note, however, that this practice is gradually becoming less frequent, because of increasing costs of maintaining a separate collection for garbage only. See e.g. P. Meier, "Wet Systems for Residential Refuse Collection: A Case Study of Springfield, Mass", U.S. Environmental Protection Agency, March 1974 (Published by NTIS, PB 234 499).

7. For a summary description of this data aquisition program, see, R.M. Clark, J.M. Sweeten, and D.G. Greathouse, "Basic Data for Solid Waste Pilot Study", Journal, Sanitary Engineering Division, ASCE, VOL. 98, No. SA6, p.897. 
8. See e.g., "Data Aquisition and Analysis System, Quarterly Report, January-March 1972", Report by ACT Systems to the EPA Solid Waste Management office, April 1972 (EPA Contracts 68-03-0034 and 68-03-0097).

9. Figure 2 is extracted from Meier, Note 5, supra, p.29.

10. The OBERS series $E$ projections are being used as the basis for all of the analyses of the Energy Futures study -- See, U.S. Water Resources Council: "1972 OBERS Projections, Series E Population", April 1974.

11. The city of springfield, Mass. is quite typical in this respect. Commerical refuse is picked up by regular collection trucks provided it meets the city ordinance in terms of weight and bulk. A special commercial collection is also provided on Friday nights to service the downtown business area. However, most large commercial waste generators schedule additional refuse pick-up by private contract. (See Meier, Note 5 , supra, Chapter III).

12. Again using springfield as an example, the city provides a special by appointment bulk collection service - a resident who wishes to dispose of some large bulky item calls a special office number to arrange for a disposal day.

13. Envirogenics Company, "Systems Evaluation of Refuse as a Low Sulfur Fuel", Report to the U.S. Environmental Protection Agency, November, 1971 (Published by NTIS, PB 209 271), p. II-5.

14. There is, to be sure, no shortage of individual studies focused on a particular facet of generation for a particular local area. See e.g., "Socioeconomic Factors Affecting Demand for Municipal Collection of Household Refuse", Report to the U.S. Environmental Protertion Agency by the Center for Urban Studies, University of Chicago, August 1973 (Published by NTIS, PB 225 020), which, as the title implies, analyses the Chicago metropolitan area -- or G.R. Davidson, "A Study of Residential Solid Waste Generated in Low Income Areas", U.S. Environmental Protection Agency, Report SE-83ts, 1972 , which focuses on low-income areas in Cincinnati. The problem from the perspective of a regional scale analysis, however, is the absence of a synthesis of these individual studies and the consequent lack of a data base at the appropriate scale. 
15. This is the procedure used by the Envirogenics company study in which equations were used to predict all major categories except paper, the latter being obtained by difference to the total amount projection. See Envirogenics company, Note 13, supra, p. II-6 ff.

16. For a sophisticated analysis of the Beverage Container Problem, see T.H. Bingham and P.F. Mulligan, "The Beverage Container Problem - Analysis and Recommendations", U.S. Environmental Protection Agency, Environmental Protection Technology Series Report EPA-R2-72-059, September 1972.

17. R.C. Hanson, "Combined Firing Systems for Specific Metropolitan Areas", Report by the Envirogenics Company to the U.S, Environmental protection Agency, Novemher 1971 (Publiched by NTIS, PB 207 701).

18. W. Niessen and S.H. Chamsky, "The Nature of Solid Waste", Proceedings; American Society of Mechanical Engineers, Incinerator Division Converence, 1969.

19. For a new approach to composition estimation based on production and marketing data, see F.L. Smith "A Solid Waste Estimation Procedure: A Material Flows Approach" EPA Report 530/SW-147, Mav 1975. However, this technique appears applicable only at the national level.

20. Based on Niessen and Chamsky, note 18, supra. 


\subsection{Refuse Combustion in Electric Utility Boilers}

The concept of using refuse as a supplementary fuel in utility boilers is almost deceptively simple. Shredded refuse has a heat value of some 4000 to $7000 \mathrm{Btu} / \mathrm{lb}$, which, although significantly less than the heat value of coal, at around 12,000 to $13,000 \mathrm{Btu} / \mathrm{lb}$, is nevertheless a fuel that can be burned in the suspension fired utility boilers of modern design with apparently minor modifications. The technical feasibility of the concept has been demonstrated at the Meramec generation facility of the Union Electric Company of st. Louis, Missouri. A comprehensive technical report on the pilot scale project published in 1973 concluded that the process is physically and technically feasible, under the premise that refuse would be milled to effect a particle size of about one inch, and that the milled refuse would replace approximately $10 \%$ of the heat value of the pulverized coal consumed in suspension fired furnaces. This study also found that the process can be applied by adaptation of existing technology and commercially available mechanical equipment, with the probability that essentially no further development effort would be required. Modifications to suspension fired boilers normally would be minor.

The latter finding is particularly important in view of the status of other technologies for energy recovery from refuse such as pyrolysis, whose technical feasibility (and indeed econumic feasibility) is far from assured. However, the longterm effects of refuse burning can be assessed only by fullscale testing over a reasonable period. On the basis of the pilot-scale st. Louis project, potential operating problems are 
probably minimal, but potential long-term corrosion and bottomash handling problems have yet to be fully assessed.

Physical facilities are needed for size reduction of the raw refuse to about one-inch particle size, for removal of metals and other heavy materials by air density separation, for storage (since refuse is normally collected only on five weekdays, whereas boiler operation is continuous), and for modification of the boiler units and necessary ancillary conveyance facilities, The size reduction and ferrous metal removal could be done either at separate transfer façilities within the oity or at the current disposal site, with truck haul to the boiler unit (the first option was used in St. Louis, as indicated schematically on Figures 5 and 6 ). If the boiler were located nearer the center of population, refuse collection trucks could deliver directly to it, and truck transfer would be eliminated. As noted in section 5.4 this could bring considerable savings but would require sufficient land at the boiler site for additional equipment and storage areas. It would also be more likely to pose institutional problems, as discussed in Chapter VI.

By mid-1974, Union Electric consluded that the demonstration experiments were successful enough to warrant full-scale implementation. A program to burn some 8000 tons/day at the Meramec and Labadie generating stations is now being implemented, with the estimated $\$ 70$ million capital cost being financed by pollution control revenue bonds (which, not being subject to income taxes, carry somewhat lower interest rates). The utility will conduct the entire operation itself, and orders for the refuse processing, storage and haul equipment have been placed over the past year.

The success of the St. Louis experiments has led to wide interest in this concept. The EPA solid waste management program 


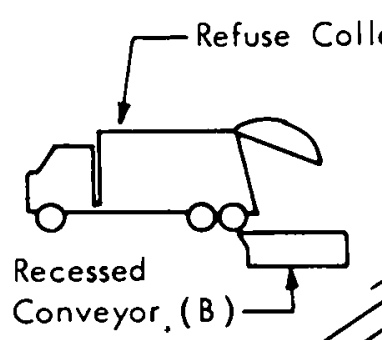

Vibratory Feeder (D), (F)

Conveyor (G)

Belt Conveyor (C)

Surge $\operatorname{Bin}(\mathrm{H})$ Hammermill ( $E$ )
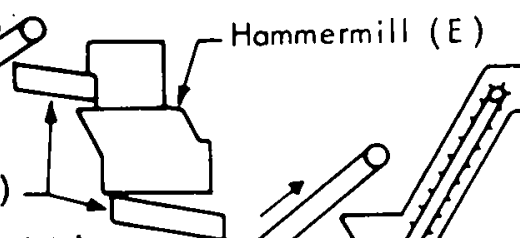

)

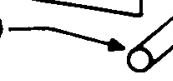

Air Density Separator

Magnetic Separator ( $Q$ )

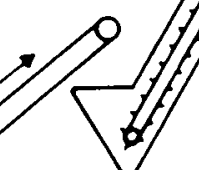

$9 \square$

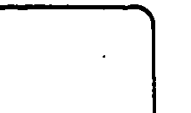

Feeder (1)
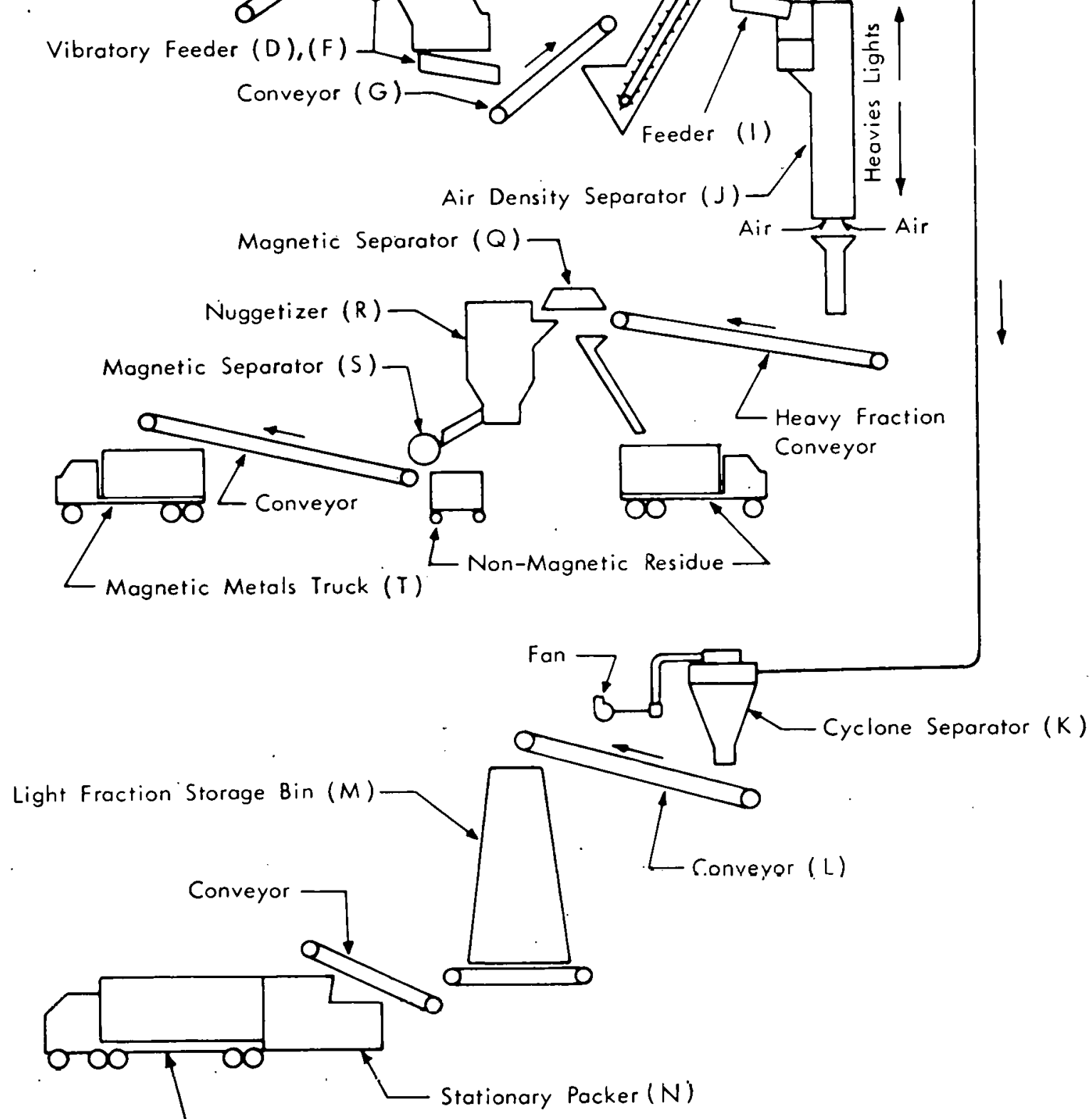

Self=Unloading Trur.k $(\Omega)$

Figure 5. Refuse processing facilities for refuse firing (Source: Dille + Klumb, note 37 , p. 2-11). 


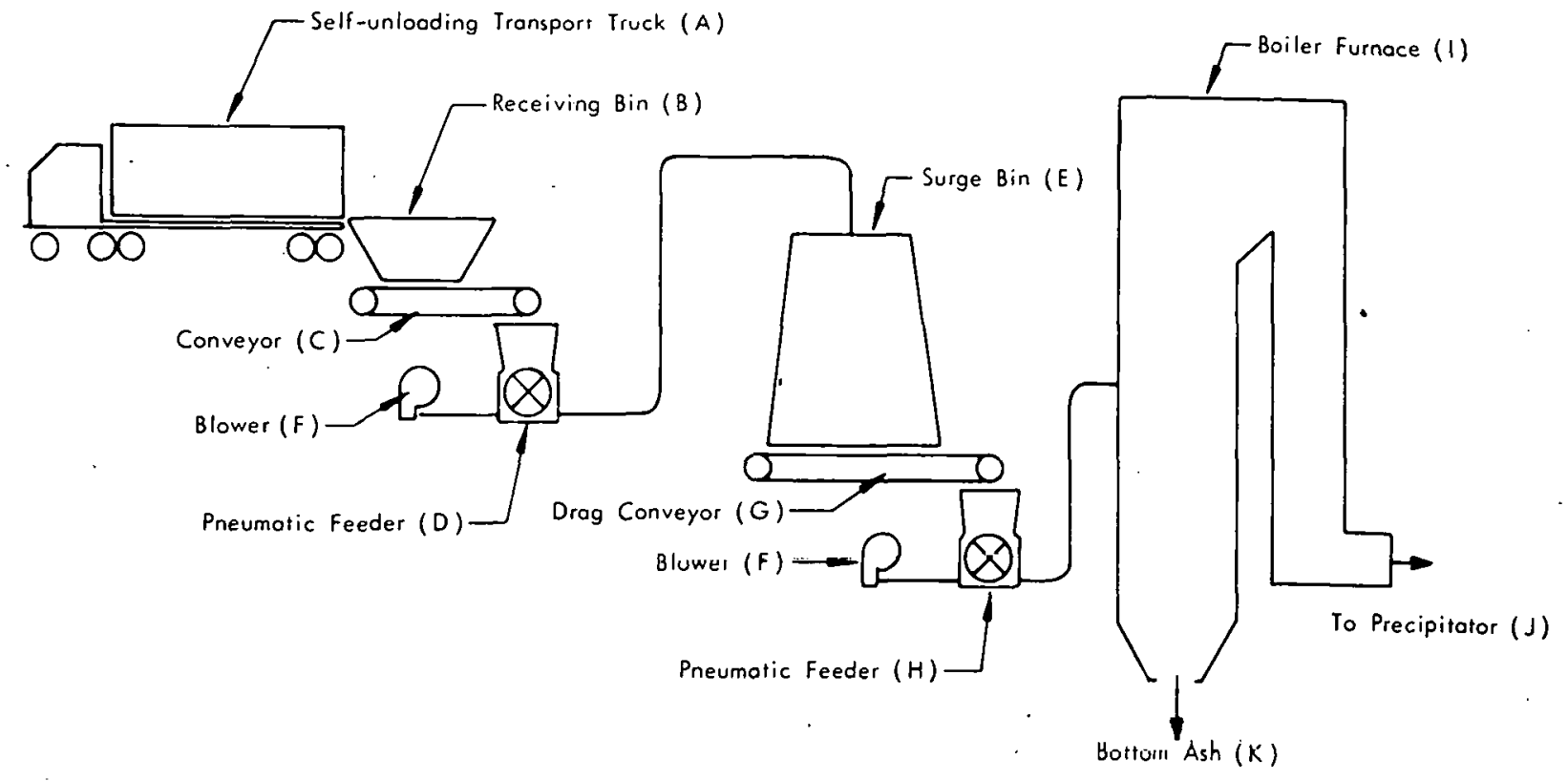

Figure 6. Refuse firing facilities at the Union Electrice Meramec Plant (Source: Dille + Klumb, note 37, p. 2-10).

has been sponsoring studies in this area since 1970, including a major systems evaluation by the Envirogenics Company, ${ }^{2}$ a survey of utility boilers in all states having significant amounts of fossel generation ${ }^{3}$, and detailed research analyses of the st. Louis project results focused on air pollution implications. 4

In the Northeast, several statewide solid waste managomont plans are focused on use of the combustible fraction of refuse as a fuel. In connecticut plans are currently being implemented for 1800 tpd plants in New Britain and Bridgeport. Other projects in the Northeast that anticipate the use of direst refuec firing in utility boilers include one sponsored by the Hackensack Meadowlands Development Commission in New Jersey; a 1500 tpd plant in Newton, Connecticut, that will supply the $22.5 \mathrm{Mw}$ municipally 
iwned power plant in Wallingford; a 2000 tpd project in Monroe County, New York, to supply the Rochester Gas and Electric Company boilers; a 1200 tpd project in Montgomery County, Maryland, serving the Potomac Electric Power Company's Dickerson plant; and a 1500 tpd project in the City of New York at Consolidated Edison's Arthur Kill plant. Further details on these are given in Appendix $\mathrm{F}$.

The use of refuse as a supplementary fuel at utility boilers raises three immediate questions of some importance to the Northeast. The first concerns the effect of low load factors on the economics of the concept; many Northeastern utilities have very little coal-fired generating capacity and what they do have is relatively old and inefficient and therefore of low plant load factor (See Appendix E). But, although obviously the utilization of the capital investment for modifying boilers for refuse burning is better at high than at low load factors; proper economic analysis takes this into account, as discussed in Chapter $V$. Note also that Commonwealth Edison in Chicago, which has one of the highest proportions of nuclear capacity in the country, plans to use refuse as a fuel at a coal plant with a load factor well below $50 \% .5$

The second question relates to the use of refuse at oil-fired rather than coal-fired plants, the two obvious problems being particulate emissions and ash handling. Since refuse has a much higher ash content than oil, burning it in an oil boiler may require the installation of precipitators and bottom ash handing equipment besides burner modifications. Northeast Utilities is current.ly embarking on a two-year experimental project with the Connecticut Resource Recovery Authority to evaluate supplemental firing of refuse at its Devon Unit 7 and 8 , which are jo MW units built in 1955, currently using No. 6 fuel oil but 
originally designed for coal. Consolidated Edison in New York City also plans to burnrefuse at its oil-fired Arthur Kill facility. 7 At present, however, the concept of refuse firing in oil boilers must be regarded as unproven. 8

The third question concerns the use of refuse at industrial boilers other than utility plants. A.D. Little, in a detailed market survey on the potential use of refuse as a fuel supplement in Massachusetts in $1973^{9}$, found that of 33 major industrial fuel users interviewed, 6 showed definite interest, 3 showed some interest, and 24 no interest, whereas, of 11 utilities interviewed, 6 showed definite interest, 2 some interest, and 2 no interest. The rated capacity of utilities with definite interest was 34,216 $\mathrm{x} 10^{6} \mathrm{Btu} / \mathrm{hr}$ (or 18000 tons of refuse/day), but the industries with definite interest had a potential for only $968 \times 10^{6} \mathrm{Btu} / \mathrm{hr}$ (or 520 tons of refuse/day). 10 These are 1973, pre-embargo data, and subsequent fuel cost increases may have changed the attitude. of some industrial fuel users. Moreover, to what degree these relative results have regional generality remains somewhat questionable. Nevertheless, it does seem that the primary potential users of refuse as supplementary fuel are the electric utilities rather than industrial users. 11

Finally, it should be noted that Combustion Equipment Associates (CEA) and A.D. Little have developed a high density, high heat value fuel having a number of advantages over the type produced by conventional shredding and gross separation of refuse prior to combustion. 12 Called Eco-Fuel-II, it is a finely powdered substance with a bulk density 4 to 5 times that of shredded fuel. It can also be made into briquettes with handling characteristics similar to those of lump coal, or slurried with residual oil in amounts up to $40 \%$ by weight. CEA has been awarded two contracts for Eco-Fuel-II, in the greater Hartford region and in the Housatonj valley region. 13 


\subsection{Bioconversion Methods}

Anaerobic decomposition of the organic fraction of solid waste to produce methane is the bioconversion method currently considered most promising. ${ }^{14}$ optimal conditions require addition of nutrients, especially potassium and nitrogen, that do not occur in normal municipal refuse in sufficient quantities to maintain the appropriate microbial balances. It has been verified experimentally that sewage sludge represents the ideal additive in this respect, and several successful polot demonstrations have confirmed the technological feasibility of the concept. ${ }^{15}$ Anaerobic digestion is a wet operation, and size reduction of the incoming refuse is done in hydropulpers to form a slurry of typically 4 to $6 \%$ solids concentration. After magnetic separation of ferrous metals and removal of glass, ceramics, and nonferrous metals by hydrocyclones, the slurry goes to anaerobic digesters similar to those now used in sewage treatment plants. The product gas is about $50 \%$ methane and $50 \%$ carbon dioxide ${ }^{16}$, and it has a heat value of 500 Btu per standard cubic foot (scf). This product gas might need some degree of further treatment, expecially for removal of hydrogen sulfide, and, if it is to be sold for pipeline gas supply augmentation, the carbon dioxide would also need removal. ${ }^{17}$ Figure 7 indicates a possible process for such an energy. recovery operation.

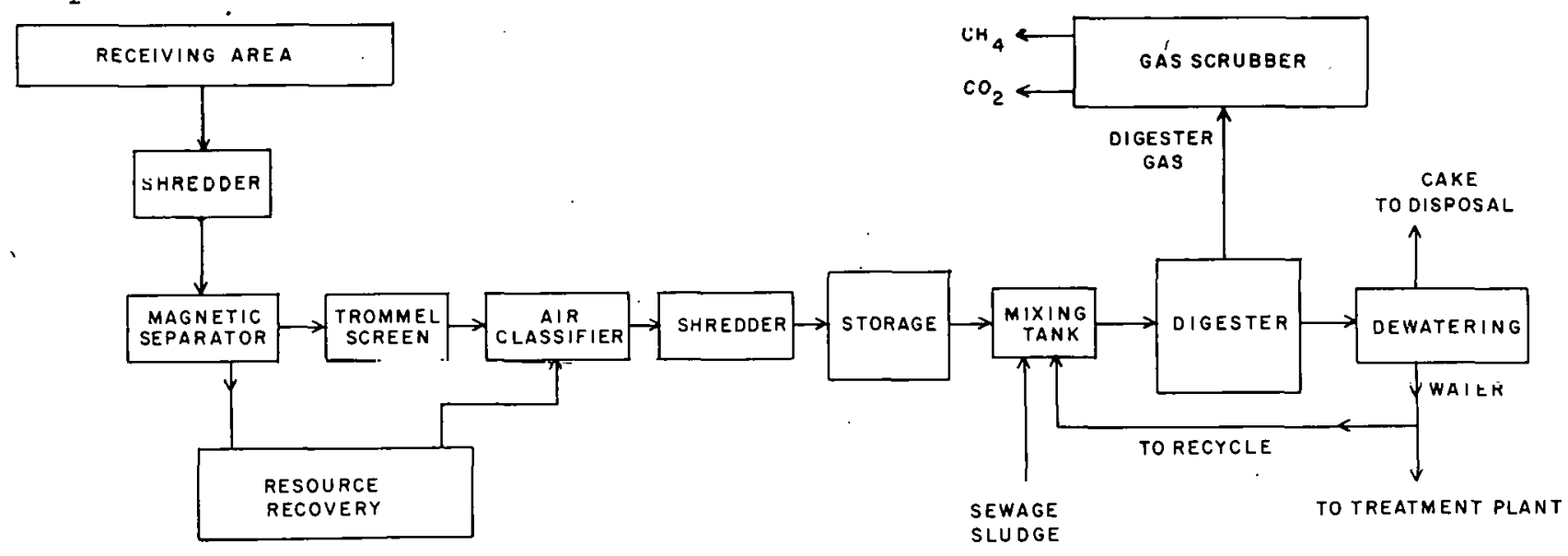

Figure 7. Process configuration for refuse bioconversion (Source: Kispert et al, tote $38, \mathrm{p} .15$ ). 
The attractiveness of the anaerobic digestion option rests primarily in its production of an energy source that is under increasingly severe supply constraints in the U.S., especially in the Northeast, which has no indigenous supply of natural gas. A number of pilot-scale projects have shown the technical feasibility of digestion, and plans are under way for a demonstration-scale facility. ${ }^{18}$ This option was also to have been a part of the NASA integrated utilities demonstration project at the Johnson, Texas, space center, but the project has been cancelled because of funding difficulties.

Interest has also been shown in obtaining methane from sallitary lanatills, and the success of a demonstration project by the Los Angeles Department of Water and Power (LADWP) has led to plans for implementation of the concept. Engineering estimates suggest that a full scale project could recover $600 \times 10^{6}$ scf/year over 15 years, enough to produce $4 \mathrm{MW}$ at a neighboring LADWPowned oil/gas fired plant some two miles from the dump. ${ }^{19}$ Pacific Gas and Electric is also experimenting with a lāndtïll gas recovery system at Mountain View, California, but its aim is to serve interruptible gas customers rather than to generate electricity.

In the Northeast, the recovery of methane from landfills has little general potential, although it may be worthwhile in some instances. 20 since landfill sites in our study area are increasingly difficult to find, conversion to methane at recovery facilities, and thus avoiding the need for landfilling, appears to be more pronising.

\subsection{Pyrolysis and Chemical Conversion Methods}

Pyrolysis, or destructive distillation, is a process in which organic material is heated to high temperatures in an 
xygen free or low oxygen atmosphere. Unlike combustion in an excess of air, which is highly exothermic, pyrolysis is endothermic. Pyrolysis of the organic fraction of refuse results in breakdown of the organic constituents into. three major fractions: a gaseous fraction consisting primarily of hydrogen, methane, carbon monoxide and carbon dioxide; a liquid fraction (liquid at room temperatures), consisting of relatively volatile organic acids, acetones and aldohols (typically acetic acid, methanol and acetone); and a solid residue known as "char", consisting of almost pure carbon plus any inert materials present. Residence time, temperature, and pressure can be controlled in a pyrolysis reactor to produce various combinations of gas, liquids and char.

Although a number of pyrolysis systems are under investigation, this discussion is restricted to the three most fully developed: the Monsanto LANDGUARD system, the Garrett Process, and the Union Carbide PUROX system. For a good review of the state of the art of pyrolysis, and the various systems currently under investigation, see Baum \& Parker. 21

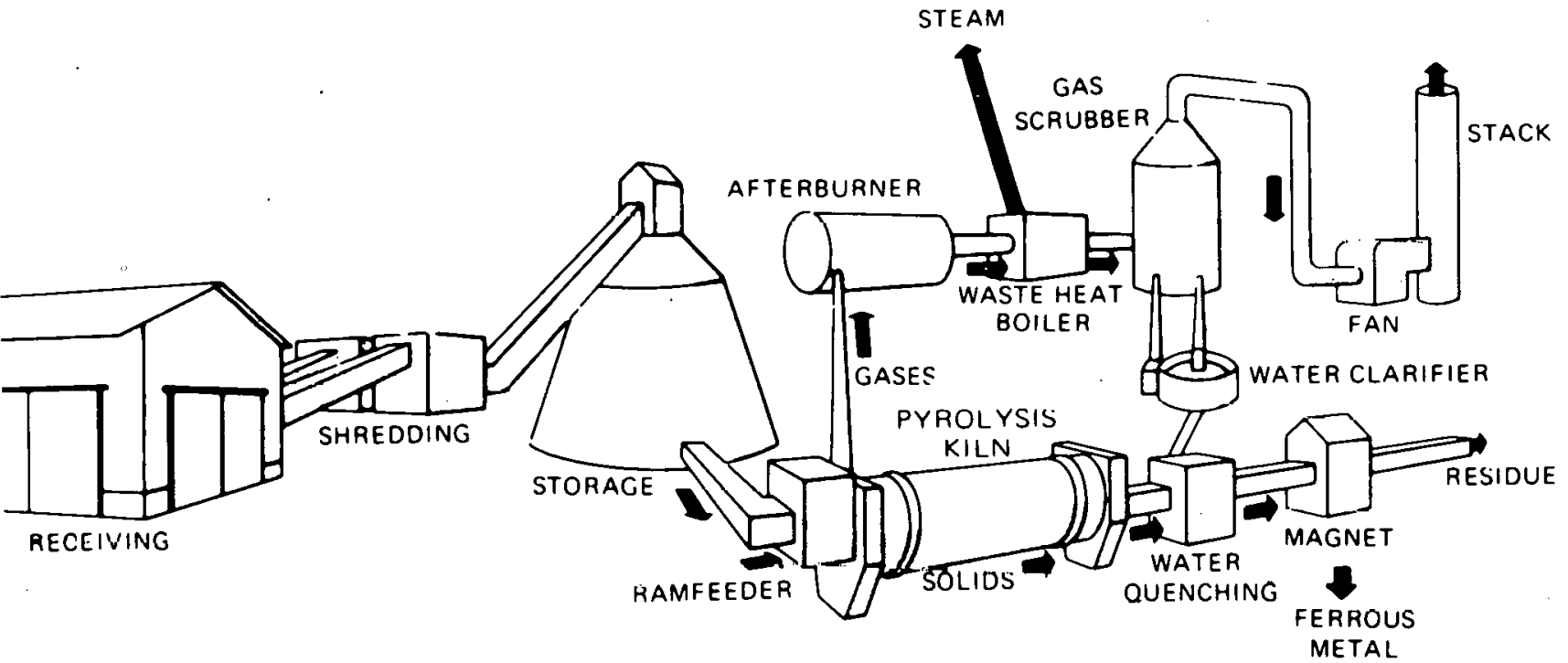

Figure 8. The Monsanto pyrolysis process (Source: Levy, note 22, p. 10). 
The Monsanto system (Figure 8) is designed as a total resource system, with energy recovery as only one of its objectives. 22 The shredded waste is pyrolyzed at temperatures of about $1800^{\circ} \mathrm{F}$, to produce a low Btu gas (100 Btu/cf), which is burned in an afterburner to generate steam. A 35 tpd prototype facility demonstrated the feasibility of the process, and a 1000 tpd facility is now operating in Baltimore, with about 4.8 million pounds of steam per day being sold to the Baltimore Gas and Electric Company for uoc in its steam distribution system.

The Garrett process (Figure 9) requires a very finely shredded input to the pyrolysis reactor, which rapidly heats the one-eighth inch particles to as high as $16.50^{\circ} \mathrm{F} .23$ oil, gas, and char are collected from the reactor and all of the gas and onethird of the char are used to supply heat for the refuse dryer and the pyrolysis reactor. The net yield of oil is claimed to be about 1 barrel (or $4.78 \times 10^{6}$ Btu) per ton of raw refuse processed.

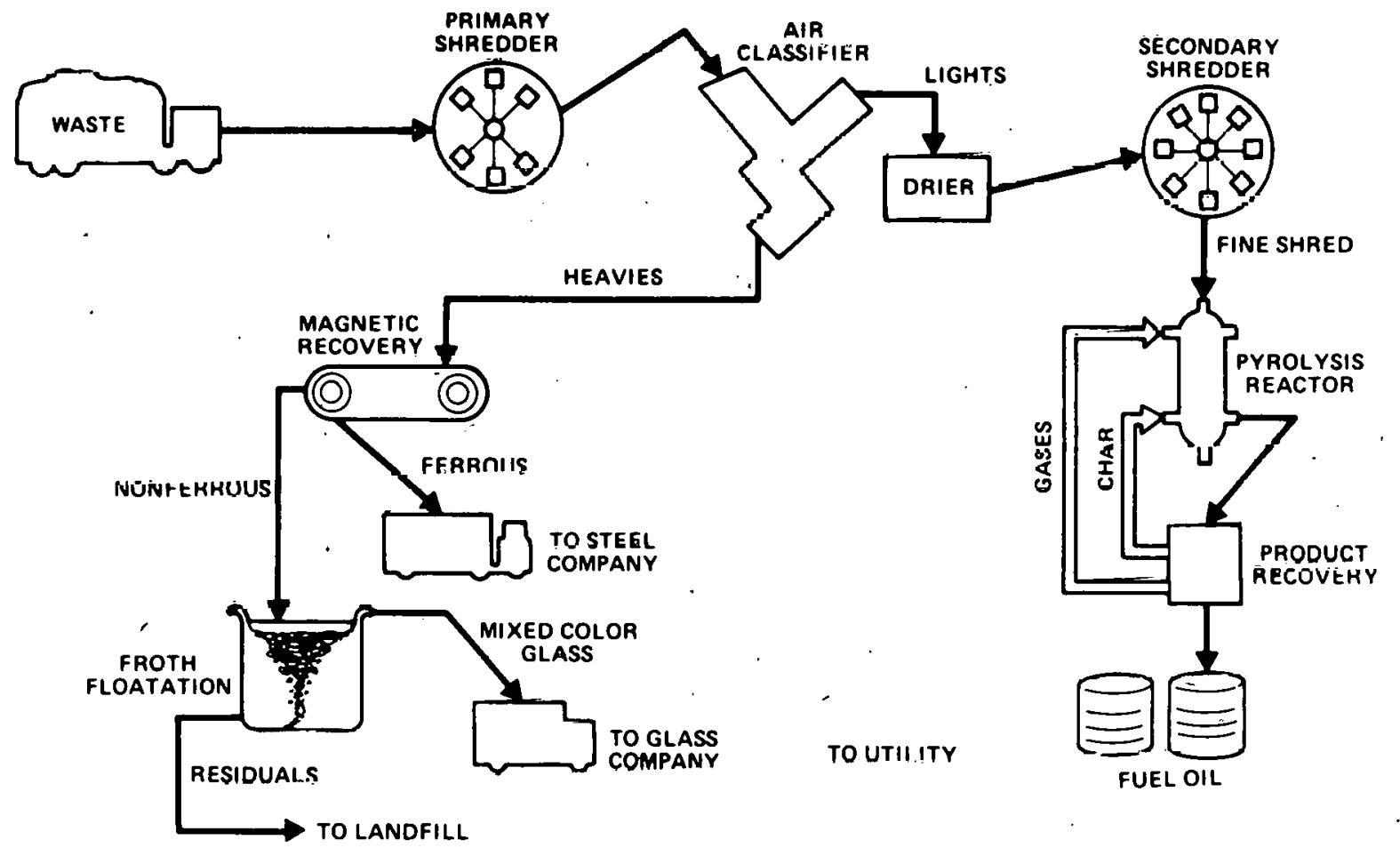

Figure 9. The Carrett pyrolysis process (Source: Levy, note 22, p. 19). 
1 desirable characteristic of this oil is its very low sulfur content, about 0.1 to 0.3 percent sulfur by weight. The oil (given the tradename Garboil) is suitable as a supplementary fuel in utility boilers for poiver generation, but its chemical properties are quite different from those of normal crude oil and it could not be refined in a typical oil refinery to produce, say, gasoline and lubricating oils. ${ }^{24}$ The other distinctive property of this oil is its high viscosity, which requires warming to about $106^{\circ} \mathrm{F}$ for pumping. However, it has an atomization temperature of $240^{\circ} \mathrm{F}$, only $20^{\circ} \mathrm{F}$ higher than normal fuel oils, so that it burns well in oil fired utility boilers.

A 4 tpd pilot plant at Laverne, California has proved the feasibility of the Garrett system, and a 200 tpd demonstration plant is now under construction for the San Diego county towns of Escondido and San Marcos, California. ${ }^{25}$ The oil is to be sold at $\$ 2.32$ per barrel for power generation to the San Diego Gas and Electric company. ${ }^{26}$ The net operating cost of the facility is expected to be about $\$ 8 /$ ton, compared with the $\$ 10 /$ ton conventional disposal cost in the area. Garrett claims that a 2000 tpd plant would show a zero net disposal cost, and a 500 tpd plant, under municipal ownership a cost of about $\$ 2.50 /$ ton, competitive with almost all properly operated sanitary landfills. ${ }^{27}$

Union carbide has developed a gas pyrolysis process known as the PUROX system, whose key element is a vertical shaft furnace, as shown on Figure 10. Refuse is fed into the top of the furnace. Oxygen entering at the base of the furnace reacts with the char that is one of the end products ultimately formed from the refuse. This reaction generates a temperature high enough to melt and fuse the ash, metal, and glass; this molten material drains continuously into a water-filled tank. where it solidifies as a hard ranular material. ${ }^{28}$ The hot gases formed by reaction of the 


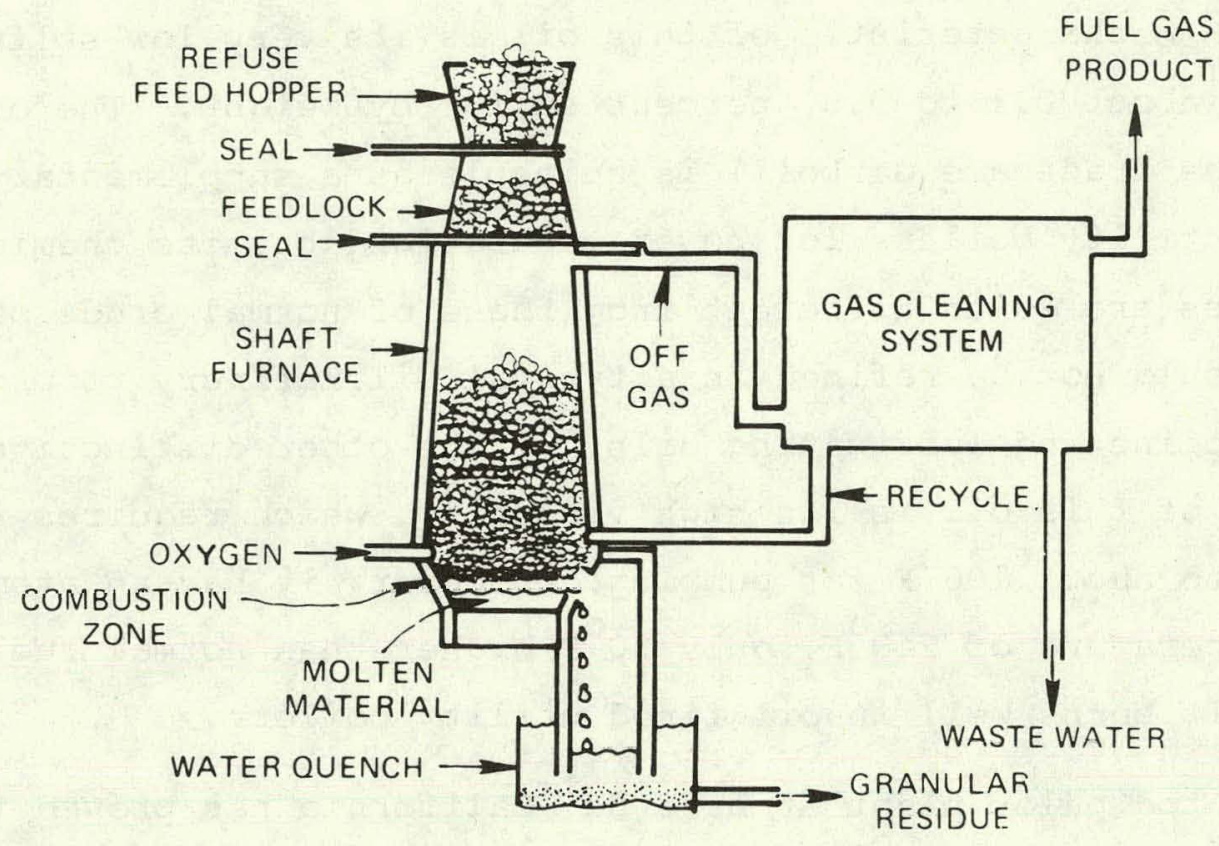

Figure 10. The Union Carbide pyrolysis process (Source: Levy, note 22, p. 11).

oxygen and char rise through the column pyrolyzing the refuse to gas and char, and in the upper portion of the furnace, serving to dry the incoming refuse. The gases leaving the furnace are at about $200^{\circ} \mathrm{F}$, and they contain considerable water vapor, some oil mist, and minor amounts of other undesirable constituents, which are removed in a gas-cleaning system.

The resultant gas is a clean-burning fuel comparable to natural gas in combustion characteristics, but its heating value of about 300Btu per cubic foot is only 30 percent that of natural gas. The gas is essentially free of sulfur compounds and nitrogen oxides and burns at about the same temperature as natural gas. It can be substituted for natural gas in an existing facility; the only plant modification necessary would be 
enlargement of the burner nozzle to increase the volumetric flow rate.

The feasibility of this process has been demonstrated at a 200 tpd facility in Charleston, West Virginia, and Mount Vernon, New York, plans to implement this system at a 400 tpd level to serve the Westchester County communities of Mt. Vernon, N. Pelham, Pelham, and Pelham Manor. The gas will be used to generate electricity, which will be sold to Consolidated Edison.

\subsection{Steam Generation}

Of all the options for energy recovery from refuse, steam generation as an adjunct to incineration has the longest history. The technology has been developed to very. sophisticated levels in Europe, where historically higher energy costs, and urban development suited to district heating, have made energy recovery by so-called waterwall incinerators almost commonplace. But American technology in this area is quite undeveloped, and the few steam generation projects that have been built have either been plagued by operating problems, or encountered difficulties in marketing the steam. For example, a 240 tpd waterwall incinerator in Braintree, Massachusetts, which started operation in 1971, has only very recently been able to sell steam to nearby industries; 29 and the largest U.S. heat recovery incinerator, the Chicago Northwest Incinerator, had such severe reliability problems that even three years after start-up, it was unable to market steam to potential industrial customers. 30

Since the oil embargo, however, the sharp rise in the cost of fuel oil for industrial process heat has caused a resurgence of interest in steam generation from refuse to serve both large industries and urban district heating systems. The largest efuse-to-energy project in the Northeast, now under construction 
in Saugus, Massachusetts, will burn 1200 tpd of refuse from 16 suburban Boston communities in Swiss designed Von Roll incinerators, and sell the entire steam output to an adjacent manufacturing facility of the General Electric Company. 31

As noted in Chapter $V$, steam generation for industrial. process heat use is more attractive economically than any pyrolysis process. However, even in the absence of detailed data on the extent of industrial use, the opportunities to implement this option appear rather limited in the Northeast. The distance between the steam generator and the user must be kept as short as possible, as the heat loss and transportation penalties are rather high. 32

The other major potential market for steam is for district heating, but here again the present opportunities are rather limited. In 1973, only eight cities in the Northeast had district heating systems, generally quite small systems in the downtown area: Allentown, Baltimore, Harrisburg, Hartford, Boston, New York, Philadelphia, and Pittsburgh. ${ }^{33}$ Numerous other commercial and campus district heating systems do of course exist in the region, but these are typically too small to be candidates for major refuse-to-energy projects.

The paucity of existing maxkets notwithstanding, steam generation from refuse has undoubted merits under the existing energy price conditions. Indeed, a new district heating system in downtown Nashville, ${ }^{34}$ using refuse as its major fuel, has recently been initiated, perhaps an encouraging precedent for a more widespread implementation of the concept in other parts of the Nation. 


\section{i.5 Other Energy Recovery Options}

Two other energy recovery options deserve some attention, although they will not be discussed further in the analytical chapters of this report in view of their still rather experimental nature.

The first is the CPU-400 system, for generating electricity by the Brayton gas turbine cycle which has been under development with EPA funding for a number of years. ${ }^{35}$. In this process, refuse is shredded and burned in a high temperature fluidized bed combustion chamber, and the hot exhaust gases are used to generate electricity in a gas-turbine generating unit. A demonstration scale, 80 tpd plant now operating is planned to be scaled up to $1000 \mathrm{tpd}$, but the design of several key systems has yet to be completed, and process economics are still uncertain.

The other possibility is to use solid waste as the raw material for low-Btu gas production by a process called hydrogasification. ${ }^{36}$ In this process, carbonaceous feed material is reacted with hydrogen to produce methane, but a portion of the feed material is used as an energy source for hydrogen manufacture. The composition of refuse (Table 5 ) is not altogether different from that of lignite and oil shale, and the proponents of the concept claim that it is economically attractive. 


\section{Table 5 \\ TYPICAL ULTIMATE ANALYSES OF SOLID WASTES AND SOME FOSSEL FUEL FEED STOCKS FOR CONVERSION TO PIPELINE GAS}

\begin{tabular}{|c|c|c|c|c|c|}
\hline $\begin{array}{c}\text { Material } \\
\text { Source }\end{array}$ & $\begin{array}{c}\text { Lignite } \\
\text { N. Dakota, } \\
\text { Beulah } \\
\text { Seam } \\
\end{array}$ & $\begin{array}{c}\text { Oil Shale } \\
\text { Colorado } \\
\text { Green River } \\
\text { Deposit } \\
\end{array}$ & $\begin{array}{c}\text { Bituminous } \\
\text { Coal, } \\
\text { Pennsylvania } \\
\text { Pgh. Seam } \\
\end{array}$ & $\begin{array}{c}\text { Subbi tuminous } \\
\text { Coal, } \\
\text { Wyoming } \\
\text { Monarch Sean }\end{array}$ & $\begin{array}{l}\text { Solid Waste } \\
\text { Average } \\
\text { Municipal } \\
\text { Refuse } \\
\end{array}$ \\
\hline Carbon & 42.4 & $23.8^{a}$ & 76.6 & 54.6 & 35.4 \\
\hline Hydrogen & 6.7 & 2.6 & 5.2 & 6.4 & 4.4 \\
\hline Oxygen & 43.3 & 12.3 & 6.2 & 33.8 & 28.2 \\
\hline Nitrogen & 1.7 & 0.5 & 1.6 & 1.0 & 0.4 \\
\hline Sulfur & 0.7 & 1.0 & 1.3 & 0.4 & 0.2 \\
\hline \multirow[t]{2}{*}{ Ash } & 6.2 & $\underline{59.8}$ & 9.1 & 3.8 & $31.4^{\mathrm{b}}$ \\
\hline & $101.0(\mathrm{sic})$ & 100.0 & 100.0 & 100.0 & 100.0 \\
\hline Moisture & 34.8 & 0.2 & 2.6 & 23.2 & 20.7 \\
\hline
\end{tabular}

a. Includes ash, metals, glass, and ceramics.

b. Includes $4.6 \%$ carbon as carbonate.

Source: Feldman, note 36, p. 128. 
1. Hormer and Shiffrin, "Solid Waste as a Fuel for Power Plants", U.S. Environmental Protection Agency, 1973 (Published by NTIS. PB 220 316). An interim report was published as EPA report SW-36d.i in 1972 .

2. Envirogenics Company, "Systems Evaluation of Refuse as a Low Sulfur Fuel", Report to the U.S. Environmental Protection Agency, Nov. 1971 (Published by NTIS, PB 208271 ).

3. Gordian Associates, Inc., "Where the Boilers Are: A Survey of Electric Utility Boilers with Potential Capacity for Burning Solid Waste as a Fuel", Report to the U.S. Environmental Protection Agency, 1974 (Published by NTIS, PB 239 392).

4. L.J. Shannon, et al, "St. Louis/Union Electric Refuse Firing Demonstration Air Pollution Test Report", Report by the Midwest Research Institute to the U.S. Environmental Protection Agency, August 1974 (Published by NTIS,PB 237 630).

5. J.J. McDonough "Solid Waste Management: A Metropolitan Viewpoint" A.I.Ch.E. Workshop on Industrial Process Design for Pollution Control, Chicago, I1l. Oct. 1973,, p. 104.

6. Bechtel Corporation "Fuels from Municipal Refuse for Utilities: Technology Assessment" Report to Electric Power Research Institute, March 1975 (NTIS Report PB 242 413).

7. R.A. Low "Energy Conversion in New York" Proceedings, First International Conference on Conversion of Refuse to Energy, Montreux, Switzerland, Nov., 1975, p. 250.

8. It could be argued, of course, that since oil is the more expensive fuel than coal, supplementary tiring of refuse at an oil fired plant would justify higher capital investment for plant modification than at coal fired plants.

9. A.D. Little, Inc. "A Systems Evaluation of Alternative Statewide Resource Recovery Techniques for the disposal of Municipal Solid Waste" Report to the Mass. Dept. of Public Works, Dec. 1973.

10. Even if all major industries were to have shown interest, the potential would be only 854 tons of refuse/day. 
11. However, again that is not to say that refuse would not be used at small industrial facilities if local circumstances are favorable. For a discussion, see e.g. H.G. Rigo, S.A. Hathaway and F.C. Hildebrand "Preparation and use of refuse derived fuels in industrial scale applications". proceedings, First International Conference on Refuse Conversion to Energy, Montreux, Switzerland, November 75, p.22.

12. R.M. Benningson, et.al. "Production of Eco-Fuel-II from Municipal Solid Waste" Proceedings, First International Conference on the Conversion of Refuse to Energy, Montreux, Switzerland, Nov. 1975, p. 14.

13. See Appendix $F$ for further description of these projects.

14. A number of other possibilities have been suggested over the past years, including formentation of cellulose to yield ethyl alcohol (based on the Madison wood sugar process developed during World War II at the U.S. Forest Products Laboratory in wisconsin) see e.g. Drobney, et al, "Recovery and Utilization of Municipal Solid Waste:, U.S. Environmental Protection Agency, Report SW-loc, 1971, p. 81.

15. In 1973, NSF held a conference to review the state-uf-the-ait of anaerobic digestion of refuse -- see Proceedings of the Bioconversion Energy Research Conference, Institute for Man and Environment, University of Massachusetts, Amherst, Mass., 1973.

16. The exact ratio of $\mathrm{CO}_{2}$ to $\mathrm{CH}_{4}$ is determined by the $\mathrm{pH}$ of operation; $\mathrm{CH}_{4}$ contents of more than $60 \%$ do not appear feasible. Sct is the abbreviation for standard cubic feet, the volume under standard pressure and temperature conditions.

17. The Dynatech Corporation suggests the use of monoethanolamine (MEA) scrubbers to effect the removal of acid gases.

18. See e.g., Kispert, note 38, Infra, by Pfeffer at the University of Illinois and by Goulecke at the University of California (See C. Goulecke, "Bioconversion of Energy Studies at the Univergity of California in Proceedings, Note 15 , supra).

19. As reported in Electrical World, August 1, 1975, p. 27.

20. For example, the Town of Brookhaven on Long Island, New York, is investigating the possibility of collecting methane at its 
Holtsville dump. Anticipated production is about $1.5 \times 10^{6}$ $\mathrm{ft}^{3} /$ day, to be piped directly into the gas distribution system of The Long Island Lighting Company (as reported in the Three Village Herald, Feb. 11, 1976). Another project proposes to extract methane from the Fresh Hills landfill in New York City for sale to the Brooklyn Union Gas Company. (see R. A. Low "Energy Conversion in New York", PROCEEDINGS, First International Conference on Conversion of Refuse to Energy, Montreux, Switzerland, Nov. 1975, p. 254).

21. B. Baum, and C. H. Parker: "Solid Waste Disposal: Vol 2, Reuse/Recycle and Pyrolysis", Ann Arbor Science Publishers, Inc., Ann Arbor, Michigan, 1974.

22. See e.g., S. J. Levy, "Markets and Technology for Recovering Energy from Solid Waste", U.S. EPA Report SW-130, 1974.

23: See e.g., C. S. Finney and D.E. Garrett, "The Flash Pyrolysis of Solid Wastes", Energy Sources, Vol. 1, No. 1, p. 295 (1974).

24. The oil has a heat value of about $10,500 \mathrm{Btu} / 1 \mathrm{~b}$, lower than the $18,200 \mathrm{Btu} / 1 \mathrm{~b}$ for a typical No. 6 fuel oil because of its higher oxygen content. Since the specific gravity of the oil is about 1.3 , as opposed to 0.98 for No. 6 , its energy content by volume is about $75 \%$ that of No. 6 .

25. Funding for $75 \%$ of the construction will come from EPA, and San Diego Gas and Electric will invest $\$ 150,000$ to handle the recovered fuel oil.

26. The selling price is based on the comparable cost of interruptible natural gas.

27. Finney \& Garrett, Note 23 , supra, at p. 313.

28. See Levy, Note 22 , supra.

29. Levy, Note 22 , supra.

30. Midwest Research Institute, "Resource Recovery: The State of Technology", Report to Council on Environmental Quality, (Feb. 1973, p. 7).

31. See e.g., "Refuse to Energy Plant Uses First Von Roll Incinerators in the U.S." Environmental Science and Technology, vol. 9, No. 5, p. 423 (May 1975). 
32. A two mile maximum distance is a figure that often appears in the literature.

33. International District Heating Association, 1973 Rate Reference Book, cited in Levy, Note 22 , supra, p. 15.

34. See below, Chapter VI.

35. See, Midwest Research Institute, Note 30 , supra, p. 9-10.

36. H. F. Feldman, "Pipeline Gas from Solid Wastes", In A.E.Ch.E. Symposium Series, Vol. 68, 1972, "Chemical Engineering Applications in Solid Waste Treatment", No. 122 , p. 125.

37. E. K. Dille and D. L. Klumb, "Recycling Solid Waste for Utility. Fuel and Recovery of other Resources", PROCEEDINGS, 1973 Conference on Frontier of Power Technology, Oklahoma State University.

38. R. G. Kispert et al. "Fuel Gas Production from Solid Waste" Report to NSF, JulY 1974 (NTIS PB 338 068). 
CHAPTER IV

THE POTENTIAL CONTRIBUTION TO ENERGY

SUPPLIES IN THE NORTHEAST

\subsection{Energy Yield from Combustion}

The energy yield from refuse combustion depends primarily on the composition of the refuse and its moisture content. Appendix $A$ derives the relationship between refuse composition and Btu content per ton of raw refuse; the resultant values used in this study are given in Table 6 . Note that the heat value of refuse is anticipated to rise as a result of expected increases in the combustible fraction, and that our values are consistent with the assumptions of other studies.

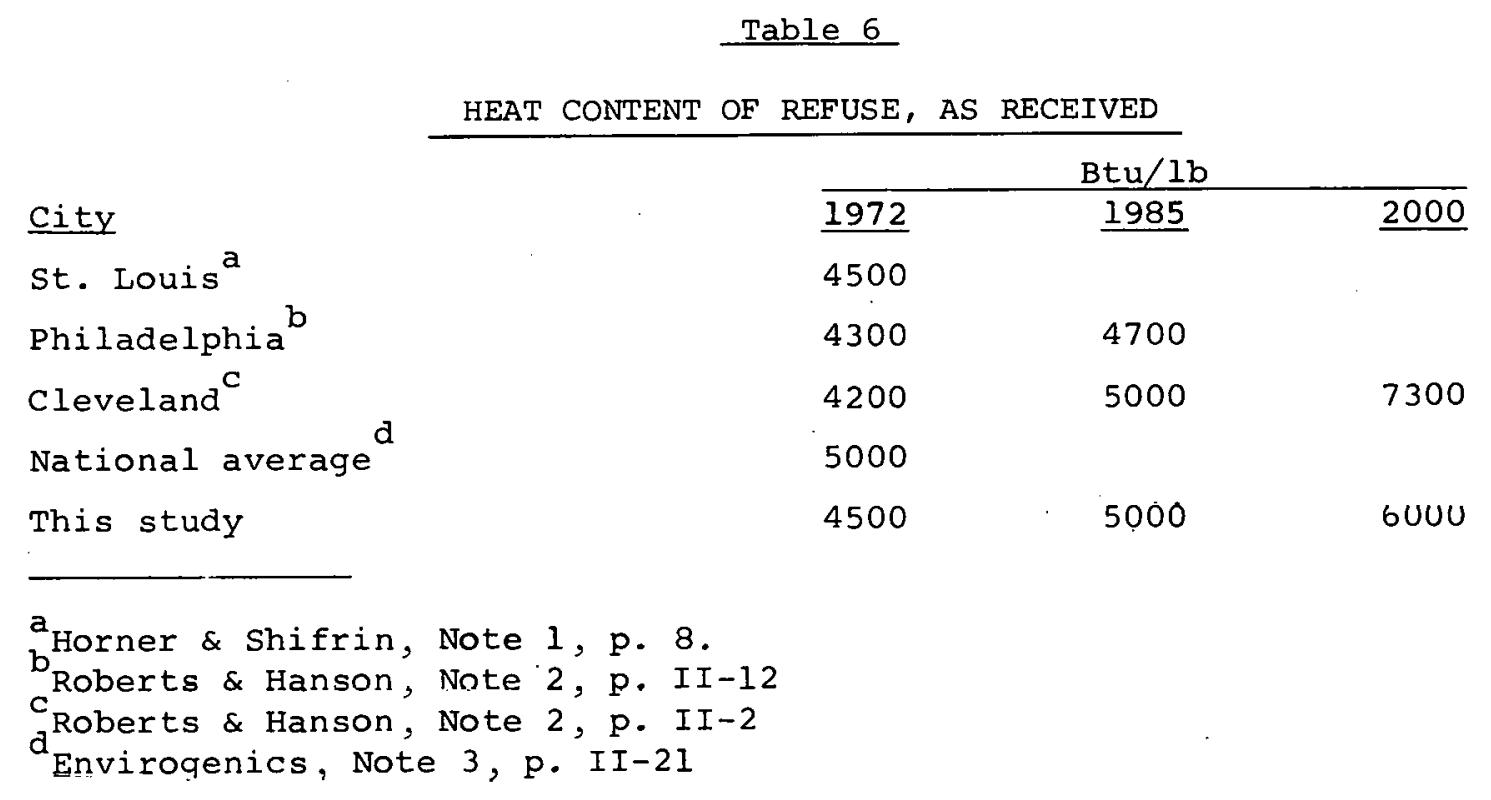


Although the heat value represents the available But content of refuse, not all of this is converted to useful heat. In fact, the experiments at the St. Louis demonstration project indicate that the combustion efficiency is a function of the percent of refuse fired, and varies little with moisture content, refuse composition or the output power of the boiler. At 9 percent firing, combusion efficiency was between 65 and $70 \%$, rising to between 80 and $95 \%$ at an $18 \%$ firing rate and $98 \%$ at a $27 \%$ firing rate. Denoting refuse combustion efficiency as $\eta_{R^{\prime}}$ and $h_{r}$ as the heat value of coal in $B t u / 1 b$ then the potential coal saving, $C_{T^{\prime}}$ in 1000 tons per year, can be approximated by

$$
C_{\mathrm{r}^{\prime}}=\frac{10^{12}}{10^{3}} \mathrm{~B}_{\mathrm{T}} \eta_{\mathrm{R}} \frac{1}{\mathrm{~h}_{\mathrm{C}}} \frac{1}{2000}
$$

where $B_{T}$ is the amount of refuse consumed per year (in $10^{12} \mathrm{Btu} / \mathrm{Yr}$ ). Expressed as the amount of energy, $E_{T}$ (in Mwh/yr), that would be replaced by refuse, one obtains

$$
E_{T}=\frac{10^{12}}{10^{3}} \quad B_{T} \frac{1}{h_{g}}
$$

where $\mathrm{h}_{\mathrm{g}}$ is the average generation unit heat. rate (in Btu/Kwh), Finally, the equivalent power level, $\mathrm{P}_{T}$, (in $M w(e)$ ) is given by

$$
\mathrm{P}_{\mathrm{T}}=\mathrm{E}_{\mathrm{T}} \frac{1}{365 \times 24 \times L \mathrm{~F}}
$$

where LF is the assumed load factor.

Table 7 shows for all urban areas in the study region the computed values of $B_{T}, C_{T}, E_{T}$, and $P_{T}$ for the base case refuse generation rate and 1972 refuse composition as shown in Table 3. 
POTENTIAL YIELDS FROM REFUSE

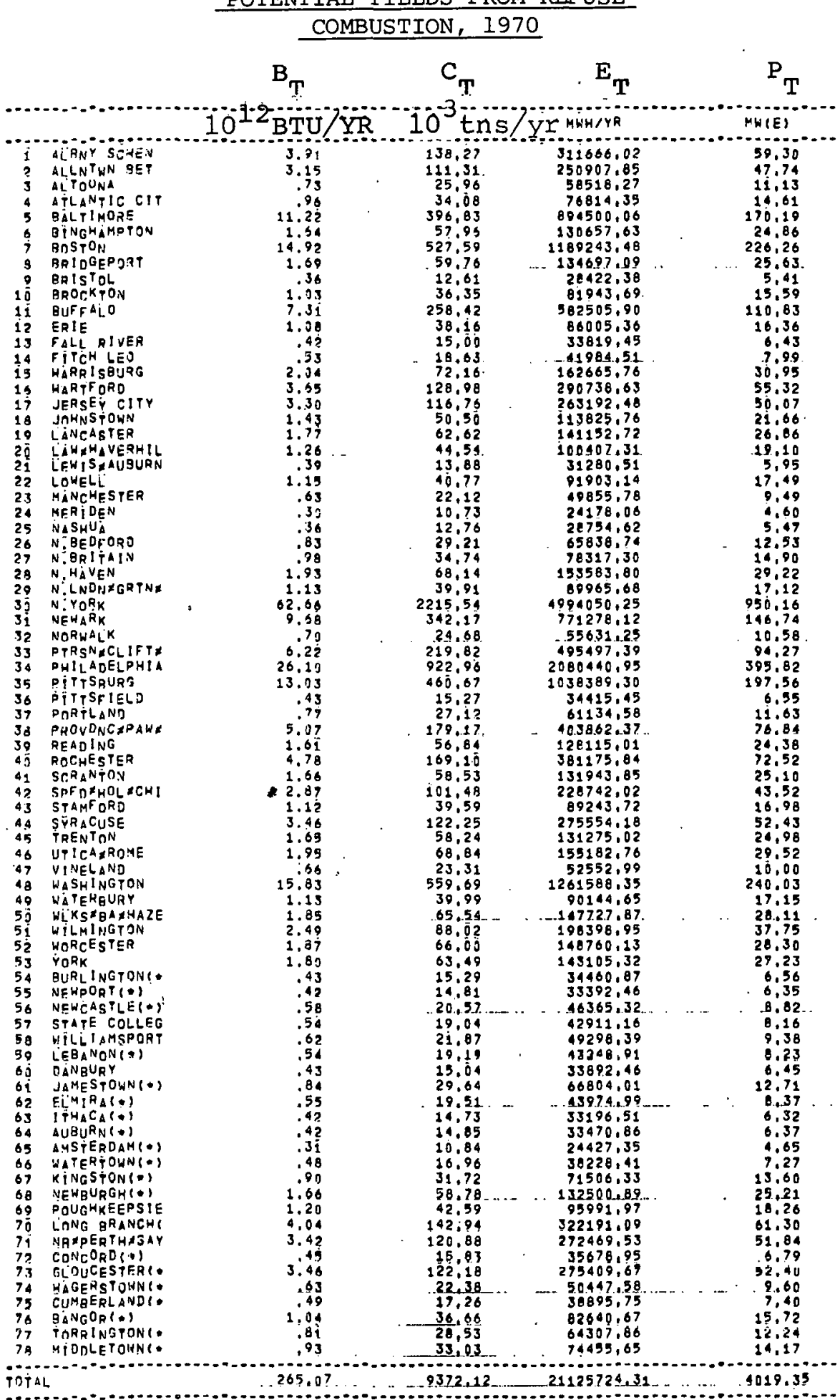

B BTIS AS

COAL AS $1: \ldots 3$ TONS/YEAR

ASSUMED REFUSE COMGUSTION EFFICIENCY AS 
These computations assume a firing rate of 18 percent, and a combustion efficiency of $\eta_{R}=.85$. The overall efficiency of refuse to electricity conversion by direct combustion is given by the product

$$
e_{C}=\eta_{R} \frac{3412.8}{h_{g}}
$$

For $\eta_{R}=.85$ and a typical heat rate of $10665 \mathrm{Btu} / \mathrm{Kwh}$, the Reference Energy system ${ }^{5}$ entry is

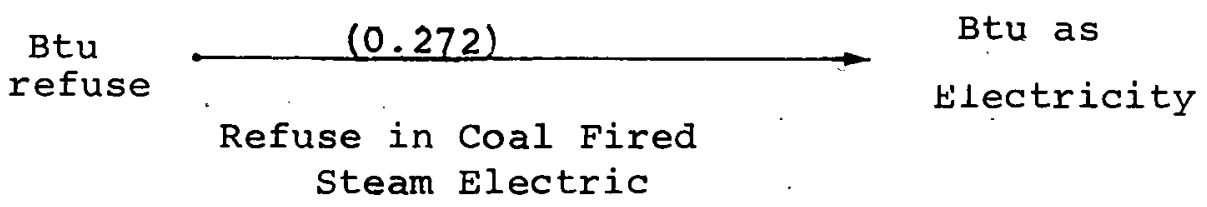

\subsection{Energy Yield from Bioconversion}

Calculation of the onergy yield frull bioconversion is considerably more difficult than in the case of combustion. Estimates of the methane yield based on experimental data vary widely, and an analytical derivation is not possible because of the complexity of the biochemical equilibria that govern the process.

Pleffer ${ }^{6}$ estimated that one pound of organic solids destroyed in the digestion process would yield some 7.1 cubic feet (scf) methane Assuming that one ton of raw refuse results in 0.6 tons of sludge solids, that the fraction. of volatile sollds is 0.6 , that 0.8 of the volatile solids are destroyed, and that the heat content of methane is $1000 \mathrm{Btu} / \mathrm{scf}$ then one ton of refuse can be shown to yield $4.09 \times 10^{6} \mathrm{Btu} / \mathrm{ton}$. 
Dair ${ }^{7}$ estimated a methane yield of $6175 \mathrm{cu}$. ft. per ton of raw refuse, or $6.175 \times 10^{6} \mathrm{Btu} /$ ton, whereas McFarland et al found gas production in a pilot scale digestor to average $7.0 \mathrm{cu}$.ft. per pound of volatile solids added to the digester, with an equivalent Btu yield of $5.04 \times 10^{6} \mathrm{Btu} / \mathrm{ton}$.

Taking an average yield of $5 \times 10^{6} \mathrm{Btu} / \mathrm{ton}$ and assuming the heat content of raw refuse to be $5000 \mathrm{Btu} / \mathrm{lb}$ and the heat content of sewage sludge to be $7300 \mathrm{Btu} / 1 \mathrm{~b}$ of solids, then, if I part by weight of sewage sludge is added to 35 parts of refuse, the overall efficiency of bioconversion is computed as

$$
\frac{5 \times 10^{6}}{\frac{35}{36} \times 5000 \times 2000+\frac{1}{36} \times 7300 \times 2000}
$$

and thus the Reference Energy system entry is

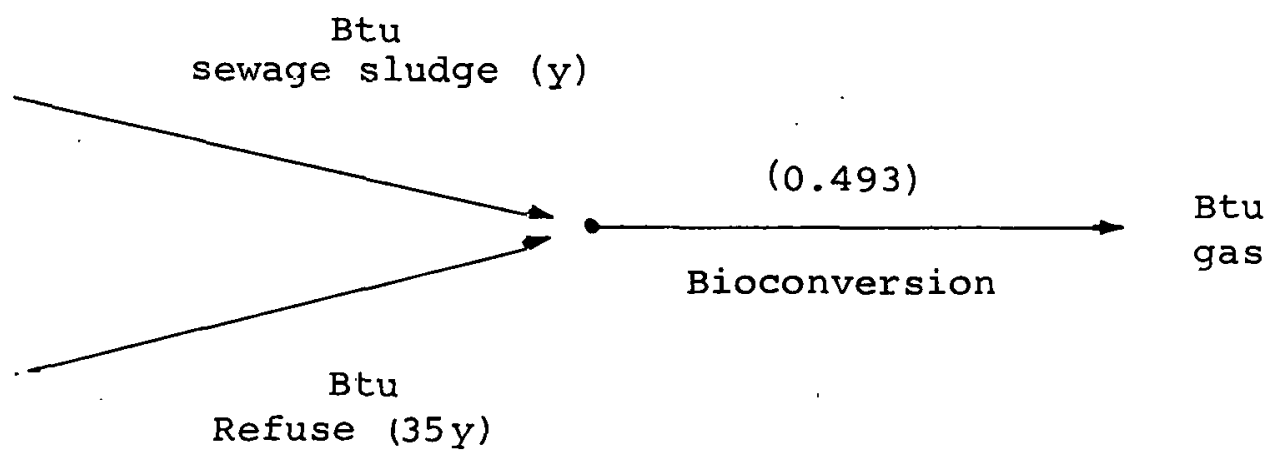

\subsection{Energy Yield from Pyrolysis}

The energy yield of the Garrett process has been estimated to be 1 barrel of oil per ton of raw refuse or $4.87 \times 10^{6}$ Btu/ton of raw refuse. 9 But, since this oil can be used only as a supplementary 
fuel in oil-fired boilers, the electric energy yield would be $4.87 \times 10^{6} \times 0.32=1.56 \times 10^{6} \mathrm{Btu} / \mathrm{ton}$. Assuming the heat content of raw refuse to be $5000 \mathrm{Btu} / 1 \mathrm{~b}$ or $10 \times 10^{6} \mathrm{Btu} / \mathrm{ton}$, the entries of Reference Energy system are thus

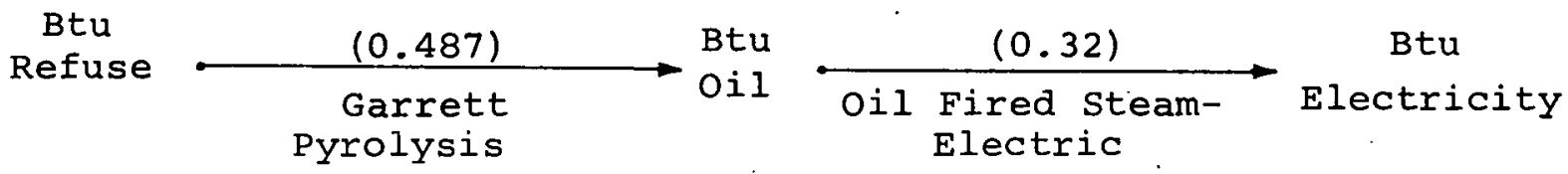

This is equivalent to an overall efficiency of 0.155 , less than half the refuse-to-power efficiency from direct firing in $11+i \mathrm{ity}$ boilers.

The Union Carbide PUROX system energy yield is estimated at $5.5 \times 10^{6}$ Btu per ton of refuse in the form of gas. ${ }^{10}$ The Reference Energy system entry is thus

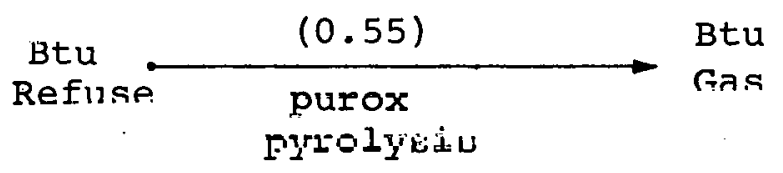

\subsection{Energy Yield from Steam Generation}

Energỹ yield from refuse via steam generation can be estimated by two methods that do not involve complicated thermodynamic computations. The first is simply to use boiler efficiency as a surrogate for conversion efficiency, but this neglects losses in transit, which may be substantial. A better method is based on consideration of lhe Btu content of the fuel being replaced by refuse. 
The Saugus, Massachusetts, steam generation plant is estimated to save General Electric some 73,000 gallons of fuel oil per day. ${ }^{11}$ At $18,200 \mathrm{Btu} / \mathrm{lb}$ and a specific gravity of 0.98 , this equals an annual Btu savings of

$300 \frac{\text { days }}{y r} \times 0.98 \times 8.34 \frac{1 b}{g a l} \times 73,000 \frac{\mathrm{gal}}{\mathrm{day}} \times 18,200 \frac{\mathrm{Btu}}{1 \mathrm{~b}}=3.25 \times 10^{12} \frac{\mathrm{Btu}}{\mathrm{yr}} \cdot$

Given a refuse input of 440,000 tons/yr and a value of $5000 \mathrm{Btu} / \mathrm{lb}$ of refuse, the overall efficiency is

$$
\frac{3.25 \times 10^{12}}{440,000 \times 5000 \times 2000}=0.73
$$

Hence, the Reference Energy System entry for a steam generation from refuse is

Btu

Refuse
$(0.73)$

Steam Generation
Btu industrial process or

Btu district heatina

\subsection{Comparative Assessment}

The total 1972 energy consumption of the Northeast has been estimated at $15.6 \times 10^{15}$ Btu. ${ }^{12}$ Assuming a 1972 population of 54.27 million, a refuse generation rate of $3.31 \mathrm{~b}$ per capita per day, and a refuse heat value of $4500 \mathrm{Btu} / \mathrm{lb}$, the yearly heat content of the region's refuse is $294 \times 10^{12} \mathrm{Btu}$, or $1.88 \%$ of total consumption. A more useful comparison, however, is by the specific resource that refuse would replace, and taking into account the appropriate conversion efficiencies. Table 8 shows the result of such 
comparisons for each of the energy conversion options examined in this report; note, however, that each option listed assumes all the available refuse would be consumed by that particular option. Thus, for example, refuse could supply $6.1 \%$ of the region's natural gas consumption $^{13}$ or, say, $18 \%$ of the coal used for utility electric generation. 
Table 8

POTENTIAL ENERGY CONTRIBUTION: TO THE NORTHEAST U.S.

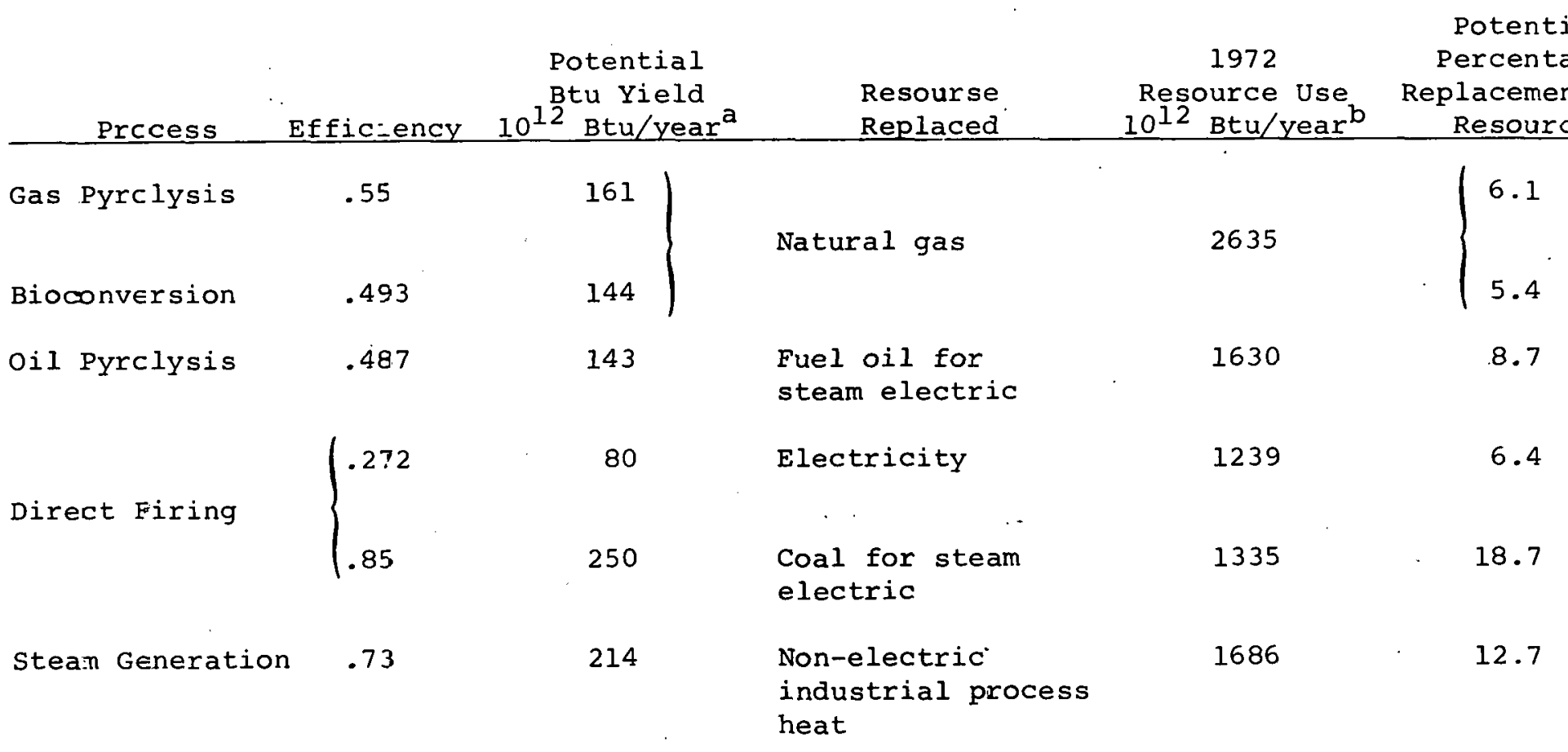

$\mathrm{a}_{\text {Based on }} 4500 \mathrm{Btu} / \mathrm{lb}$ refuse, a per capita generation rate of $3.3 \mathrm{lb} / \mathrm{cap} /$ day and 1972 estimated population of 54.27 million; equivalent to $294 \times 10^{12}$ Btu/year.

bFrom Lee, Note 12. 
1. Horner and Shiffrin, "Solid Waste as a Fuel for Power Plants" U.S. Environmental Protection Agency, Report SW-36, 1973 (Published by NTIS, PB 220 316).

2. R. M. Roberts and R. C. Hansen, "Combined Firing Systems for Specific Metropolitan Areas". U.S. Environmental Protection Agency, November 1971, (Published by NTIS, PB 207 701).

3. Environgenics Company, "Systems Evaluation of Refuse as a Low Sulfur Fuel, Volume l", U.S. Environmental Protection Agency, November 1971 (Published by NTIS, PB 209 271).

4. L. J. Shannon et al, "St. Louis/Union Electric Refuse Firing Demonstration Air Pollution Test Report", Report by Midwest Research Institute to EPA, August 1974 (Published by NTIS, PB 237 630) P. 40. The explanation for this phenomen was not addressed in any detail, and the authors of this study noted merely that ". . . while several factors may contribute to this behaviour . . " the variations in fuel micing patterns in the furnace probably can account for most of the effects."

5. For a description of the BNL Reference Energy System Model, and its application to the Northeastern U.S., See e.g. J. Lee, "Energy Supply and Demand in the Northeast United States," BNL Regional Energy Studies Program, Report 20427 , September 1975.

6. J. Pfeffer, "Reclamation of Energy from Organic Waste", U.S. Environmental Protection Agency, 1974 (Published by NTIS, PB 231 176).

7. J. Dair, "Report on a study of the Feasibility of Disposing of Rubbish into a Sewage Disposal System", Unpublished Memorandum, Los Angeles County Sanitation District, sept. 13, 1963.

8. J. McFarland et al., "Comprehensive Studies of Solid Wastes Management, Final Report", University of California at Berkeley, Calif., 1972, Report No. SERI. 72-3.

9. See above, section 3.3.

10. Ibid. 
1. "Refuse-to-Energy Pland Uses First Von Roll Incinerator in the U.S.", Environmental Science and Technology, Vol. 8, No. 8, p. 693, (August 1974).

12. Lee, Note 5 , supra, p. 13.

13. This percentage matches well with that of Kispert et al "Fuel Gas Production from Solid Waste" Dynatech R/D Company, Report to NSF, Jan 75 (NTIS, PB 245038 ), who examined the poten tial gas supply contribution on an SMSA basis. Extracting data for Northeastern SMSA's from their national survey one obtains a potential 1970 contribution of $6.5 \%$. 
‘

THIS PAGE

WAS INTENTIONALLY

LEFT BLANK 


\section{CHAPTER V}

\section{ECONOMIC ANALYSIS}

\subsection{A Framework for Analysis}

The economic analysis of alternatives for energy recovery from waste in the Northeast presents a number of difficulties. To begin with, all the systematic comparative studies of energy recovery from solid waste have been conducted from the national perspective, using national averages in the economic analysis. Because of the marked regional variations in energy costs, however, these cannot be used directly in a study focused on the Northeast. In fact, because the delivered prices of fuels in the Northeast are among the highest in the country, the results of economic analyses conducted at the national level tend to be overly conservative from the Northeastern perspective. Also, rapid changes in energy prices since the 1973 oil embargo and the accelerating inflation in construction costs have caused early obsolescence of economic studies: indeed, the most comprehensive systematic ecomonic analysis of resource recovery options, published in early 1973 for the council on Environmental Quality, is based on pre-embargo fuel valuations, with conclusions that are pessimistic in light of post-embargo market conditions. Unfortunately, because different resource recovery options produce different types of fuels, and because the relative proces of different fuels have shifted, simple extrapolation of the results of pre-embargo analyses is not possible.

Conventional economic analyses have generally been made from the viewpoint of solid waste manaqement, with all costs expressed in terms of dollars per ton of raw refuse, and comparisons made on the basis of lowest overall cost of disposal. Such analyses rest 1 certain assumptions regarding credits for recovered materials 
and energy, interest rates, depreciation, etc., integrated into the framework of conventional engineering economic analysis. The major shortcoming of this approach is its inflexibility. It reveals little about supply-demand relationships or about prices: yet a rational determination of the price for refuse, as sold by a municipality to an electric utility or privately owned resource recovery facility, is fundamental to reaching equitable agreements on implementing energy recovery projects. 2 Moreover, the relative conditions of the market for energy on the one hand and the price of refuse fuel on the other, set the framework for the entry of private capital into the energy recovery business. Obviously, therefore, a parametric approach with energy prices explicitly considered will be more useful in assessing the degree to which energy recovery from refuse will in fact be practiced in the future than the conventional engineering economics approach with fixed assumptions about energy prices.

A major problem in the economic analysis of new technologies concerns the extent of scale economies. Although most of the options considered in this report have been demonstrated at the 100 to 200-ton/day level, for which cost estimates are reasonably reliable, no large plants (1000 tpd and up) are yet operating, and reliable cost estimates are avallable for on $1 y$ two large projects, the Union Electric refuse burning project and the Saugus steam generating project, both still under construction. The proponents of the proprietary systems, such as the Garrett and union Carbide pyrolysis systems, have made cost estimates for large projects, but these should be viewed with some scepticism.

As a pragmatic expedient a simple exponential rulc is used here to scale up demonstration projects from the 100 to 200 tpd level to the 1000 tpd level that we shall use as the standard for comparison. This rule, widely used in chemical engineering process 
zconomics, ${ }^{3}$ simply states that economies of scale are captured by the expression

$$
c\left(x_{1}\right)=c\left(x_{2}\right)\left(\frac{x_{1}}{x_{2}}\right)^{b}
$$

where $c\left(x_{1}\right), C\left(x_{2}\right)$ are the capital costs of facilities of capacity $\mathrm{x}_{1}$, and $\mathrm{x}_{2}$, respectively, and the exponent $\mathrm{b}$ is typically around 0.7 for complete process plants. 4

The rapid escalation in construction costs over the past few years necessitates use of an indexing procedure to convert all estimates to Mid-1975 prices. The Chemical Engineering Plant cost Index seems to be the most appropriate to the type of facility needed for energy recovery from solid waste: values of this index over the past years are as follows: ${ }^{5}$

1970

1971

1972

1973

1974

Mid-1975
125.7

132.2

137.2

144.1

165.4

182.0

The economic analysis below rests on a computation of a breakeven refuse price for each energy recovery option, defined as that price for which the discounted present worth of annual returns equals the original investment.

i.e.

$$
\sum_{t=1}^{n}\left\{\left(s-q_{R}(t) \cdot P_{R}(t)-o(t)\right) \frac{1}{(1+i)^{t}}\right\}=I
$$


where $i=$ opportunity cost of capital

$\mathrm{n}=$ recovery period, years

$q_{R}(t)=$ quanity of refuse purchased in period $t$, tons/year

$P_{R}(t)=$ breakeven price of refuse in period $t, \$ / t o n$

$O(t)=$ other operating costs in period $t, \$ /$ year

$S=$ revenue for sale of recovered energy, $\$ /$ year

$I=$ necessary investment, $\$$

To keep the analysis tractable, assume that refuse quantities, and prices and operating costs (in constant, mid-1975 dollars) remain constant with time. 6 Then

$$
S-q_{R} P_{R}-O=C R F(i, n) \cdot I
$$

where CRF ( $i, n)$ is the capital recovery factor at. interest rate $i$ and time horizon $\mathrm{n}$. However, since the required investment is a function of the size of the facility, say in tons of refuse per year, the breakeven refuse price will also be a function of $q_{R}$. Hence, dividing by $q_{R}$ yields

$$
\frac{s}{q_{R}}-P_{{ }_{R}}-\frac{11}{q_{R}}=\operatorname{CRF}(i, n) \cdot \frac{I\left(\frac{\vdots}{u_{R}}\right)}{q_{R}}
$$

but $s / q_{R}$ is the revenue for sale of recovered energy per ton of refuse, and can also be written in the form

$$
\frac{S}{q_{R}}=P_{E} E
$$

where $P_{E}$ is the price of energy (say in $\$ / 10^{6}$ Btu) and $E$ is the energy yield, (in $10^{6}$ Btu/ton) as derived, for example, in Chapter 
IV above. $O / q_{R}$ is the operating cost per ton, say $O^{\prime}$. And, from $\mathrm{Eq} \cdot[1]$

$$
\frac{I\left(q_{R}\right)}{q_{R}}=I^{\prime}\left(q_{o}\right)\left(\frac{q_{R}}{q_{0}}\right)^{b-I}
$$

where $I^{\prime}\left(q_{0}\right)$ is the known capital cost per ton at capacity $q_{0}$, hence

$$
P_{R}=P_{E} E-O^{\prime}-\operatorname{CRF}(i, n) I^{\prime}\left(q_{o}\right)\left(\frac{q_{R}}{q_{o}}\right)^{b-1}
$$

Note that this breakeven price, even though a function of $\mathrm{q}_{R}$, is not strictly a demand function in the conventional sense. 7 In particular, the assumption has been made that the price of energy is constant, and is unaffected by $q_{R}$-- an assumption that is valid only if the quantity of energy delivered by the new refuse conversion source is too small to affect market conditions.

\subsection{Breakeven Prices for Refuse Fuel}

Direct firing: consider first the case in which municipal refuse is directly fired in a utility boiler, and the municipality owns and operates the refuse processing facility, and sells the prepared refuse to the utility in a form ready for combustion. From the utility's viewpoint, the fuel savings (which equals the cost of coal that is replaced by the refuse, minus the cost of refuse) must at least offset capital and operating costs, in accordance with the foregoing discussion. Thus, the utility's breakeven cost is given by

$$
q_{C} F_{c}-q_{R} P_{R}-O_{u}=\operatorname{CRF}\left(i_{u}, n\right) I_{u}\left(q_{R}\right) \text {. }
$$


where $q_{c}=$ Quanity of coal replaced by refuse, tons/year

$\mathrm{p}_{\mathrm{c}}=$ Price of coal; $\$ /$ ton

$\mathrm{q}_{\mathrm{R}}=$ Amount of refuse burned, tons/year

$\mathrm{P}_{\mathrm{R}}=$ Breakeven price of refuse, $\$ /$ ton

$\mathrm{O}_{\mathrm{u}}=$ Incremental operating costs, $\$ /$ year

$I_{u}=$ Capital cost of boiler modifications, $\dot{\$}$

But one ton of coal is equivalent to $h_{C} / \mathrm{nh}_{\mathrm{R}}$ tons of refuse, where $\mathrm{n}$ is the combustion efficiency of refuse, and $\mathrm{h}_{c}$ and $\mathrm{h}_{\mathrm{r}}$ are the heat values of coal and refuse, respectively. If one sets $n=.85$, $h_{c}=12020 \mathrm{Btu} / \mathrm{lb}, \mathrm{h}_{\mathrm{R}}=5000 \mathrm{Btu} / \mathrm{lb}$, then $\mathrm{q}_{\mathrm{C}}=\mathrm{q}_{\mathrm{R}} / 2.82$, and

$$
\begin{aligned}
P_{R} & =\frac{P_{c} \frac{q_{R}}{2.82}-o_{u}-I_{u}\left(q_{R}\right) \operatorname{CRF}\left(i_{u}, n\right)}{q_{R}} \\
& =\frac{P_{c}}{2.82}-o_{u}^{\prime}-\operatorname{CRF}\left(i_{u}, n\right) I_{u}^{\prime}\left(q_{R}\right)
\end{aligned}
$$

where $O_{u}^{\prime}$ is the operating cost in $\$ /$ ton and $I_{u}^{\prime}$ is the capital cost in dollars per ton of yearly capacity, at capacity $q_{R}$.

Estimates of $O_{u}^{\prime}$ and $I_{u}^{\prime}$ are available from the 1972-1973 st. Louis Demonstration Project; namely $O_{u}^{\prime}=0.118$ and $I_{u}^{\prime}=3.55 .8$ If one uses the 1972 coal cost at the st. Louis Meramec Plant of $\$ 8.85 /$ ton, 9 and an interest rate of $10 \%$, then

$$
\begin{aligned}
P_{R} & =\frac{8.85}{2.82}-.118-3.55 \times \operatorname{CRF}(10 \%, 20 y r) \\
& =\$ 2.60 / \text { ton }
\end{aligned}
$$

where $\operatorname{CRF}(10 \%, 20 y r)=0.1175$ 
This implies that the utility would find it economic to invest in the necessary boiler modifications, and burn refuse as a supplementary fuel, at any refuse cost to the utility lower than $\$ 2.60 /$ ton . If the utility had to pay more than this, the conversion would be uneconomic, and presumably would not be undertaken. On the other hand, if the price to the utility is less, then the implied rate of return on investment would be higher than the interest rate assumed in Eq.[4]. This latter situation has some interesting interpretations, discussed further in section 5.5 .

If it is assumed that delivery of municipal refuse to a utility boiler costs the same as delivery to an alternative disposal site, then the breakeven price for the municipality (which would justify investment in, and operation of, a facility that processes refuse for sale as a boiler fuel) is obtained by balancing the savings in disposal cost plus the revenue from sale of the refuse against the additional operating and capital recovery costs. Thus,

$$
q_{R}\left(P_{D}+P_{R}\right)=O_{m}+C R F\left(i_{m}, n\right) I_{m}\left(q_{R}\right)
$$

or

$$
P_{R}=\frac{\operatorname{CRF}\left(i_{m}, n\right) I_{m}\left(q_{R}\right)+o_{m}-q_{R} P_{D}}{q_{R}}
$$

where $I_{m}=$ Capital cost of the processing facility, $\$$

$i_{m}=$ Interest rate to the municipality, say $6 \% /$ year

$\mathrm{P}_{\mathrm{D}}=$ Alternative disposal cost $(=\$ 5.17 /$ ton in $\mathrm{St}$. Louis in 1972-73)

$O_{m}=$ Operating cost of the processing facility, $\$ /$ year 
On the basis of the 1972-73 St. Louis cost data

$$
P_{R}=14.16 \times C R F(6 \%, 20 y r)+3.65-5.17=\$-0.28 / \text { ton }
$$

which implies that the breakeven price is a disposal fee to the utility of $28 \%$ per ton. A considerable difference between the two breakeven prices is evident. Union Electric (in st. Loius) was receiving the refuse free of charge, which clearly made the arrangement profitable to the municipality.

In view of this wide discrepance, perhaps the proper valuation of the refuse should be such that the rate of return on investment for both municipality and utility is the same, say $\rho$. Then

$$
\sigma_{R}\left(\frac{P}{2.82}-P_{R}\right)-O_{u}=\rho I_{u}
$$

and

$$
q_{R}\left(P_{D}+P_{R}\right)-O_{m}=\rho I_{m}
$$

solving for $\rho$

$$
\begin{aligned}
& \rho=\frac{\mathrm{q}_{\mathrm{R}} \frac{{ }^{\mathrm{P}} \mathrm{c}}{2.82}-\mathrm{O}_{u}+\mathrm{q}_{\mathrm{R}} \mathrm{P}_{D}-\mathrm{O}_{\mathrm{m}}}{I_{u}+I_{m}}=\frac{\frac{{ }^{\mathrm{P}} \mathrm{c}}{2.82}+\mathrm{P}_{\mathrm{D}}-\mathrm{O}_{\mathrm{u}}^{\prime}-\mathrm{O}_{\mathrm{m}}^{\prime}}{I_{u}^{\prime}+I_{m}^{\prime}} \\
& =\frac{3.13+5.17-3.76}{17.71}=0.256
\end{aligned}
$$

Inserting this into $\mathrm{Eq} \cdot[5] \mathrm{yields}$

$$
\mathrm{P}_{\mathrm{R}}=.256 \times 14.16+3.65-5.17=\$ 2.10 / \text { ton }
$$

Note that this is not simply the average of the two previously 
calculated breakeven prices, because the interest rate for the utility in Eq.[4], and that for the municipality as used in Eq.[5], are different.

In the case that the utility accepts raw refuse, so that the utility rather than the municipality owns and operates transfer stations and size reduction and inerts separation facilities, the fuel savings must again be at least equal to the investment costs:

$$
\frac{\mathrm{q}_{R}}{2.82} \mathrm{P}_{\mathrm{C}}-\mathrm{q}_{\mathrm{R}} \mathrm{P}_{\mathrm{R}}-\left(\mathrm{O}_{\mathrm{u}}+\mathrm{o}_{\mathrm{m}}\right)=\operatorname{CRF}(i, \mathrm{n})\left(I_{\mathrm{u}}+\mathrm{I}_{\mathrm{m}}\right)
$$

hence

$$
P_{R}=\frac{P_{C}}{2.82}-\operatorname{CRF}(i, n)\left(I_{u}^{\prime}+I_{m}^{\prime}\right)-\left(O_{u}^{\prime}+O_{m}^{\prime}\right)
$$

If the 1972-73 st. Louis data are used again, with an interest rate of $10 \%$ over 20 years, then

$$
\mathrm{P}_{\mathrm{R}}=\frac{8.85}{2.82}-0.1175 \times 17.71-3.768=\$-2.70 / \text { ton }
$$

suggesting that the utility must be paid a disposal fee of at least $\$ 2.70 /$ ton. Since the city would otherwise incur a $\$ 5.71 /$ ton cost for incineration, equity would suggest the utility be paid

$$
\frac{5.71+2.70}{2}=\$ 4.20 / \text { ton }
$$

thereby giving both partners equal savings. 


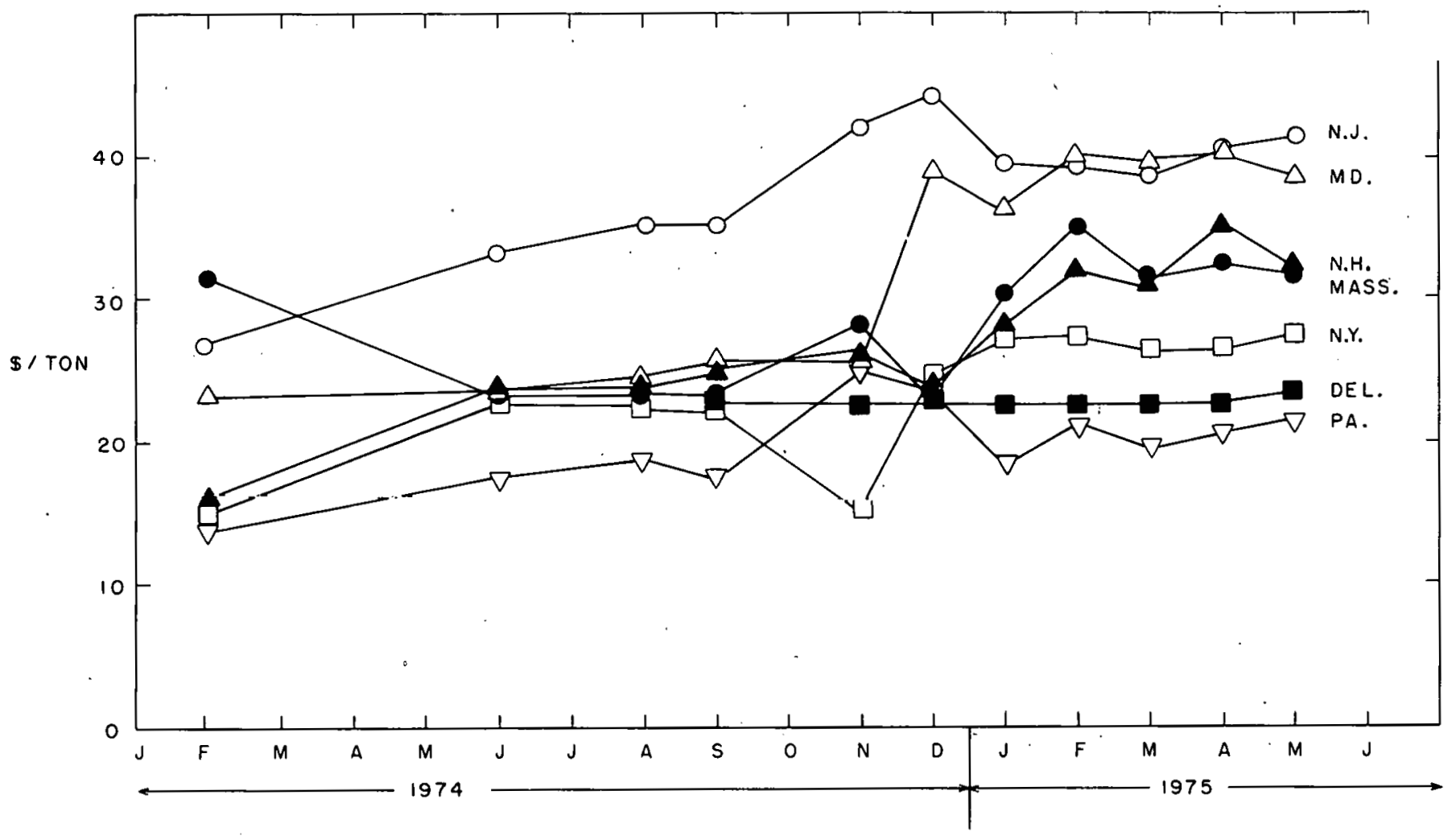

Figure 11. Coal prices, \$/ton, delivered to steam-electric plants.

An update to post-embargo coal prices in the Northeast shows a sharp rise in the'breakeven price for refuse fuel. Figure 11 shows the average contract price for coal delivered to coal burning steam-electric plants in northeastern states having such plants. 10 Note the wide variations: ranging, from $\$ 14$ to $\$ 32 /$ ton in early 1974 to $\$ 22$ to $\$ 42 /$ ton in May 1975. 11 If one uses the Union Electric capital cost estimate of $\$ 70$ million for an 8000 tpd plant, and assumes utility ownership and operation of processing facilities and a coal cost of $\$ 40 /$ ton, then the breakeven refuse price to the utility is

$$
P_{R}=\frac{40}{2.82}-3.768-\operatorname{CRF}(10 \%, 20 \mathrm{yr}) \times 23.97=\$ 7.60 / \text { ton } .
$$


vith the assumption of an 8000-tpd plant, no adjustment was made for scale effects because the cost of modifying boilers is not subject to the same scale economies as the cost of building an integrated process plant.

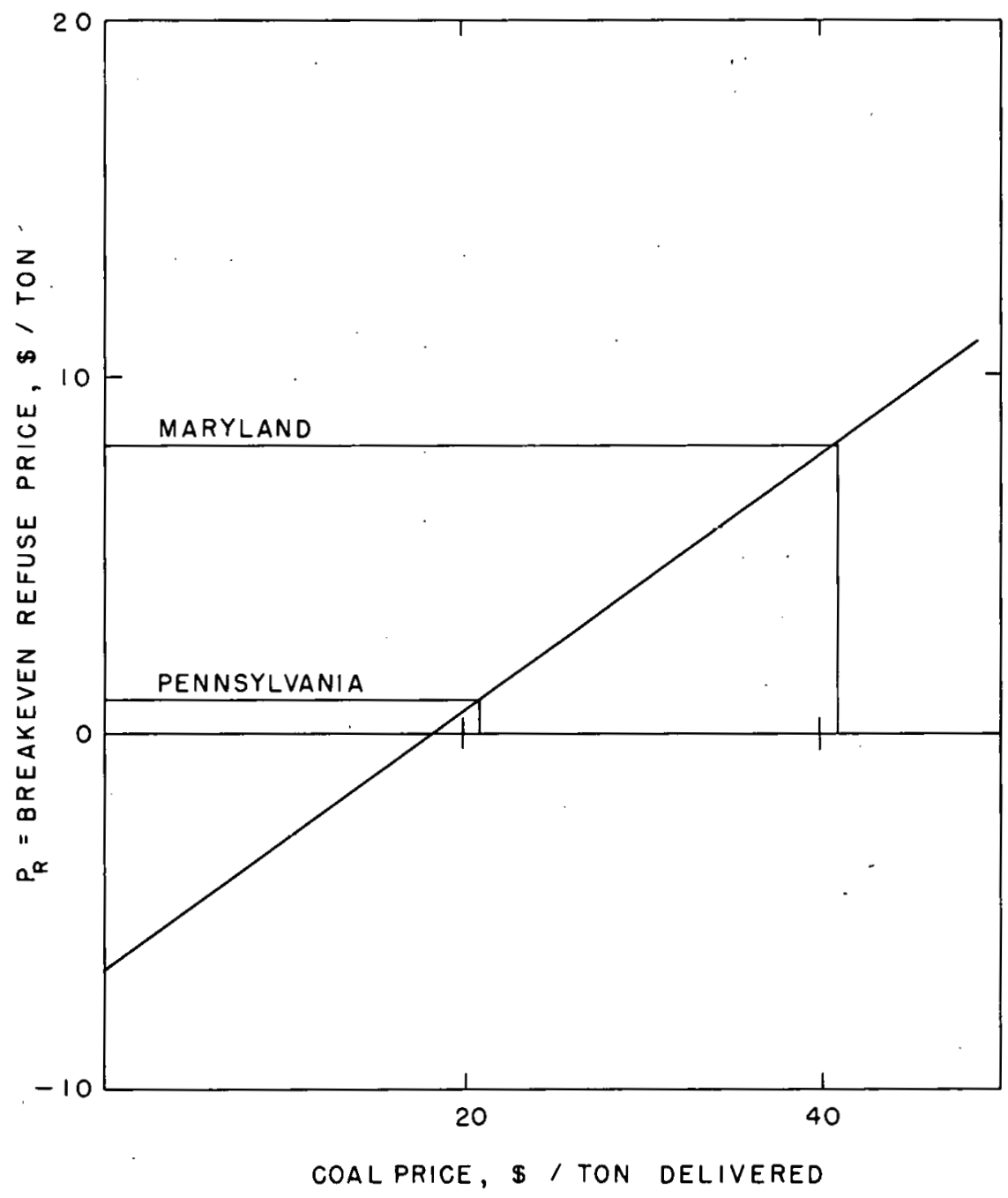

Figure 12. Breakeven refuse price. 
Figure 12 illustrates the impact of delivered coal cost on the breakeven refuse price. Although $\mathrm{P}_{\mathrm{R}}$ is a function of interest rate lowering the rate to $6 \%$ would make only a small difference (bringing $P_{R}$ to $\$ 8.32 /$ ton for $P_{C}=\$ 40 /$ ton). The range of breakeven prices in the Northeast, based on May 1975 delivered coal costs, varies from $\$ 1 /$ ton to $\$ 8 /$ ton. Note, however, that these do not include any credit for sale by the utility of the ferrous metal or inert fraction, which would make the breakeven price somewhat higher.

The breakeven cost computed above is that of refuse delivered to the generating plant. However, a full economic analysis must also take account of the cost of bringing the refuse from its source to the plants, a haul cost that may be quite substantial if the plant is not near the center of population; the cost can also be high if refuse must be hauled over long distances for alternatıve disposal.

As noted in Section 5.4., the haul costs are typically in the range $\$ 2$ to $\$ 10 /$ ton, and they can be used to generate a set of curves (Figure 13) that parallel the breakeven price curve of Figure 12 .

Figure 13 can best be explained by reference to some hypothetical examples. Consider first a municipality with a disposal cost of $\$ 2 /$ ton, say by sanitary landfill, located in Pennsylvania, where the delivered coal price is $\$ 21 /$ ton (point $A$ in Figure 13). At this coal price, the utility's breakeven price is $\$ 1 /$ ton. If the municipality's haul cost for delivery to the utility is $\$ 10 /$ ton, then landfill remains cheaper than energy recovery, but if this haul cost is only $\$ 2 /$ ton, then energy recovery is preferable. At point B, typical for a municipality in Massachusetts, and faced with a disposal cost by incineration of $\$ 8 /$ ton, and a higher coal cost, energy recovery is economic if haul costs do not exceed $\$ 13 /$ ton. 


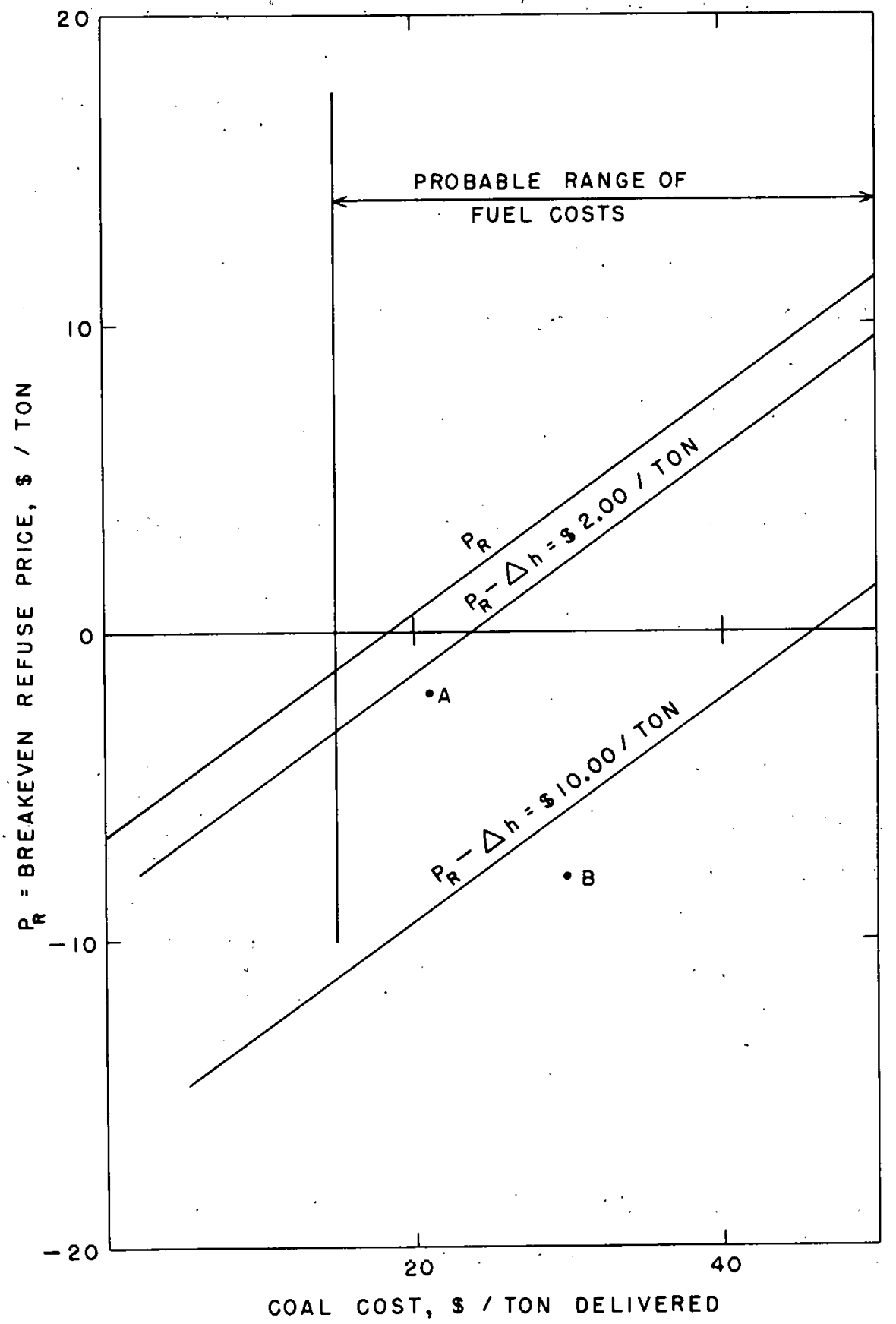

Figure 13. Decision-diagram for direct refuse firing. 
Gas Pyrolysis Consider next the options for converting refu: to gas. Here, the proceeds of gas sales must recover the investment costs, operating costs, and refuse fuel costs. Thus,

$$
q_{R} \in P_{G}-o_{G}-I_{G}\left(q_{R}\right) \operatorname{CRF}(i, n)-P_{R} q_{R}=0
$$

where $P_{G}=$ Natural gas price, $\$ /$ million cubic feet (mcf)

$\epsilon=$ Gas yield, $\mathrm{mc} f /$ ton of refuse

$O_{G}=$ operating costs, $\$ /$ year

$I_{G}=$ capilal custis at capleity $q_{R}, \$$

Converting this to the per ton form, and solving for $\mathrm{P}_{\mathrm{R}}$, then

$$
P_{R}=\varepsilon P_{G}-O_{G}^{\prime}-I_{G}^{\prime} \operatorname{CRF}(i, n)
$$

With the use of Schulz's 1975 estimates, $I_{G}(200$ tpd $)=\$ 4.74$ million and $O_{G}^{\prime}=\$ 5.51 /$ ton $^{12}$ application of Eq. [2] to the 1000 tpd (300 × 1000 tpd) level yields

$$
\begin{aligned}
I_{G}^{\prime}(1000 \operatorname{tp} d) & =\frac{4.74 \times 10^{6}}{200 \times 300}\left(\frac{1000}{200}\right)-0.3 \\
& =\$ 48.75 / \text { ton }
\end{aligned}
$$

hence, if the gas price is $\$ 0.80 / \operatorname{mcf}\left(\$ .080 / 10^{6} \mathrm{Btu}\right)$ and the gas yield $5.5 \times 10^{6}$ Btu/ton (see section 4.3 ), then

$$
P_{R}=5.5 \times 0.80-5.51-48.75 \times \operatorname{CRF}(10 \%, 20 \mathrm{yr})=\$-6.89 / \text { ton. }
$$




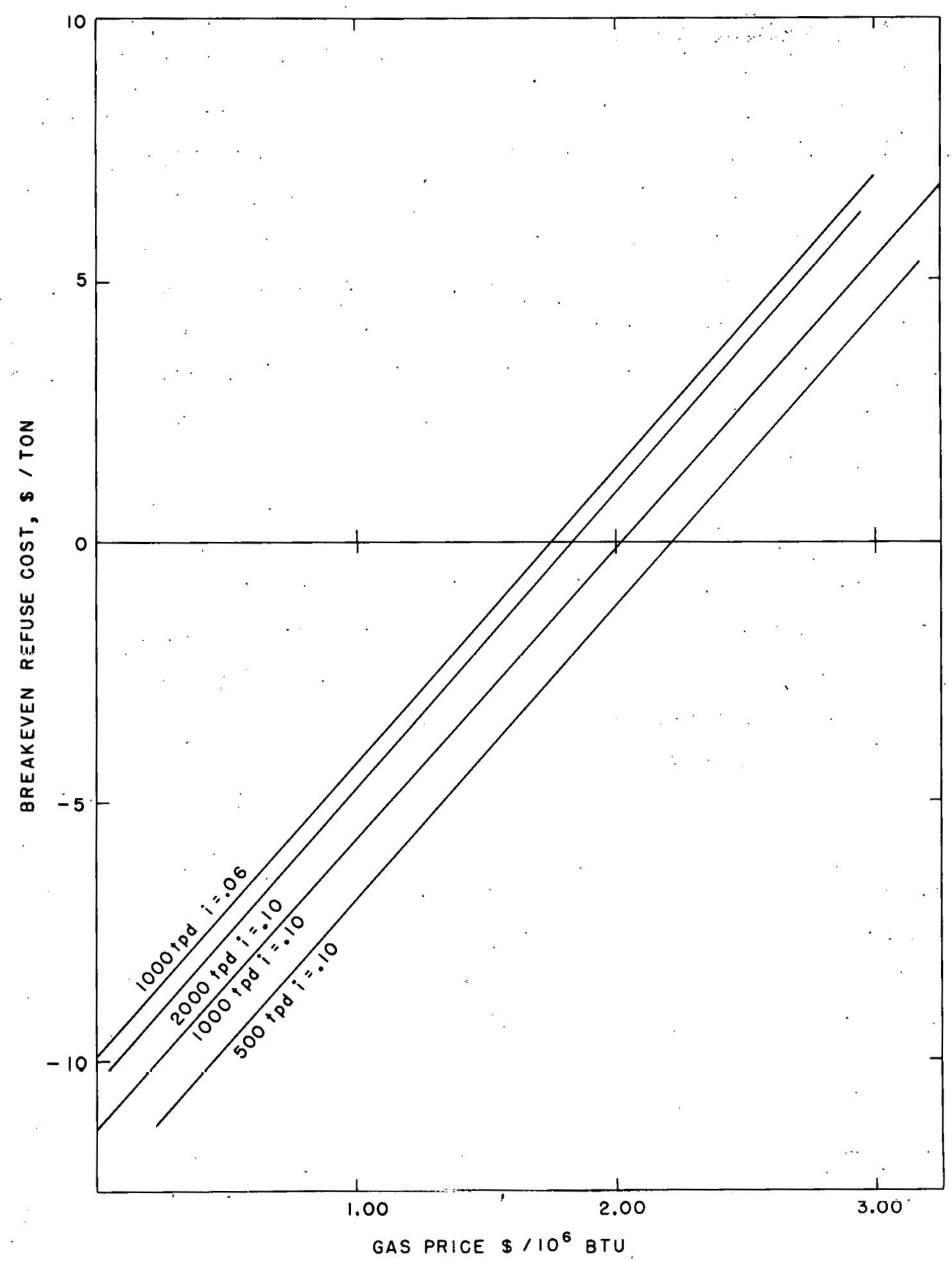

Figure 14. Decision diagram for gas pyrolysis. 
Figure 14 shows the decision diagram for the Purox pyrolysis process, derived in the same way as that for direct firing. However, because this process is much more capital intensive and therefore the interest rate is more important, curves are shown for rates of both 6 and 10\%. For this process, scale economies must also be considered explicitly; curves are therefore shown for capacities of 500,1000 , and 2000 tpd (corresponding, at a $3.51 \mathrm{~b} / \mathrm{cap} / \mathrm{da}$ refuse generation rate, to cities with populations of about 286 , 571 , and 1143 thousand, respectively). Note that decreases in interest rates and increases in plant size result in upward, parallel shifts of the breakeven cost curve.

Current information on wholesale prices for natural gas is difficult to obtain on a regionally disaggregated basis, and the most recent regional data are for 1974. 13 The FPC publishes, however, monthly reports on prices of gas delivered to electric generating plants, which may serve as a standard in estimating the value of gas recovered from refuse. FPC data for May 1975 show the following delivered prices in $\% / 10^{6}$ Btu: ${ }^{14}$

\section{Intcrruptible}

Massachusetts

Vermont

New Jersey

New York

Pennsylvania

Delaware

New Ilampshire

Maryland

$$
126.2
$$

106.0

92.8

99.3

$--$

144.0

101.1
173.0

Firm

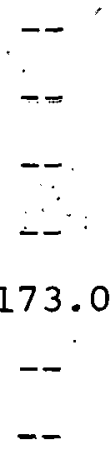

111.5 
With gas prices in this range, the breakeven refuse price, say for a 1000-tpd facility, is between -5.75 and zero \$/ton, which is significantly lower than the current range of incineration costs in the Northeast (about $\$ 15 /$ ton for a new incinerator meeting strict air quality standards) even with haul costs added to it.

Oil Pyrolysis In contrast to delivered coal prices, the prices of No. 6 fuel oil delivered to steam electric plants in the Nontheast shows relatively little variation, as seen from the May 1975 FPC statistics: 15

$\begin{array}{lcc} & \frac{\$ / \mathrm{bbl}}{12.48} & \frac{\$ / 10^{6} \text { Btu }}{2} \\ \text { Connecticut } & 12.55 & 206.5 \\ \text { Massachusetts } & 12.55 & 205.2 \\ \text { New Hampshire } & 11.35 & 183.8 \\ \text { New Jersey } & 12.78 & 214.8 \\ \text { New York } & 11.95 & 196.3 \\ \text { Pennsylvania } & 12.67 & 207.6 \\ \text { Delaware } & 11.37 & 182.0 \\ \text { District of Columbia } & 12.61 & 205.5 \\ \text { Maryland } & 11.21 & 181.3\end{array}$

Since oil produced by the Garrett pyrolysis process is suitable only as a fuel in utility boilers, ${ }^{16}$ the above prices can be used as a measure of energy recovery credits. Thus,

$$
P_{R}=\lambda P_{O}-O_{P}^{\prime}-I_{P}^{\prime} \operatorname{CRF}(i, n)
$$

where $\lambda=$ oil yield, $10^{6} \mathrm{Btu} /$ ton of raw refuse

$$
\begin{aligned}
& \mathrm{P}_{\mathrm{O}}=\text { fuel oil prices, } \$ / 10^{6} \mathrm{Btu} \\
& \mathrm{O}_{\mathrm{P}}^{\prime}=\text { operating cost, } \$ / \text { ton }
\end{aligned}
$$


$I_{P}^{\prime}=$ capital cost per ton of yearly capacity, $\$ /$ ton

hence, if one sets $\lambda=4.87$, and $\mathrm{P}_{\mathrm{O}}=\$ 2.00 / 10^{6}$ Btu, and uses the MRI $^{17} 1972$ cost estimate at the 1000 tpd level of $\$ 12.34$ million, then

$$
\begin{aligned}
P_{R} & =4.87 \times 2.0-5.78-\frac{12.34 \times 10^{6}}{3 \times 10^{5}} \frac{182}{137.2} \operatorname{CRF}(10 \%, 20 \mathrm{yr}) \\
& =\$-2.63 / \text { ton }
\end{aligned}
$$

The breakeven refuse price curve for this process is shown in Figure 15.

The best basis for an economic analysis of steam generation from refuse is the 440,000 ton/year plant now under construction in Saugus, Massachusetts. This facility has an equivalent energy recovery value (see section 4.4 ) of $3.95 \times 10^{12} \mathrm{Btu} / \mathrm{yr}$. Hence, the yield per ton, in $10^{6} \mathrm{Btu} / \mathrm{ton}$ of raw refuse, is

$$
\frac{3.05 \times 10^{6}}{440,000}=8.97
$$

The total capital cost has been estimated at $\$ 30$ million. 18 Using Eq. [I] to scale the project down to 1000 tpd yields a capital cost of

$$
30 \times 10^{6}\left(\frac{1000}{1200}\right)^{0.7}=\$ 26.3 \mathrm{milition} .
$$

Hence, the cost in $\$ /$ ton of yearly capacity is $\$ 93.66,19$ and the breakeven refuse price computes to 


$$
\begin{aligned}
P_{R} & =8.97 \times 2.0-5.78-93.66 \times \operatorname{CRF}(10 \%, 20 \mathrm{yr}) \\
& =\$ 2.12 / \text { ton }
\end{aligned}
$$

The breakeven price curve for steam generation using the Von Roll process is also shown in Figure 15.

\subsection{Process Comparisons}

Figure 16 summarizes the above results, showing the breakeven refuse prices for each of the energy recovery options: 1000-tpd plant size and $10 \%$ interest rate are assumed, and all fuel prices have been converted to $\$ / 10^{6}$ Btu.

Several conclusions can be drawn at this point. The most striking is that direct firing in utility boilers is by far the best energy recovery option. It presupposes, however, that coalfired boilers are available for conversion, which is not true for all SMSAs. The next best option is steam generation for industrial process heat, but this is not universally applicable either, as it presupposes a large industrial process steam user reasonably near a sizable population concentration and having an adjacent site for the energy conversion facility (so that heat losses and steam transmission. costs can be kept to economic levels).

The data in Figure 16 imply that a municipality forced to incineration, which is likely to cost $\$ 15$ to $\$ 20 /$ ton because of air pollution standards, will almost certainly elect to use some energy recovery process. Even if neither direct firing nor steam generation is possible, one of the pyrolysis technologies will still result in a lower disposal cost than incineration.

In the absence of a coal-fired plant that can be converted to refuse firing or a large industrial process steam user, the economic advantage for a city projecting continued disposal by sanitary landfill will probably depend on the incremental haul cost. A. city $: h$, say a $\$ 3 /$ ton landfill cost, and an incremental haul penalty of 


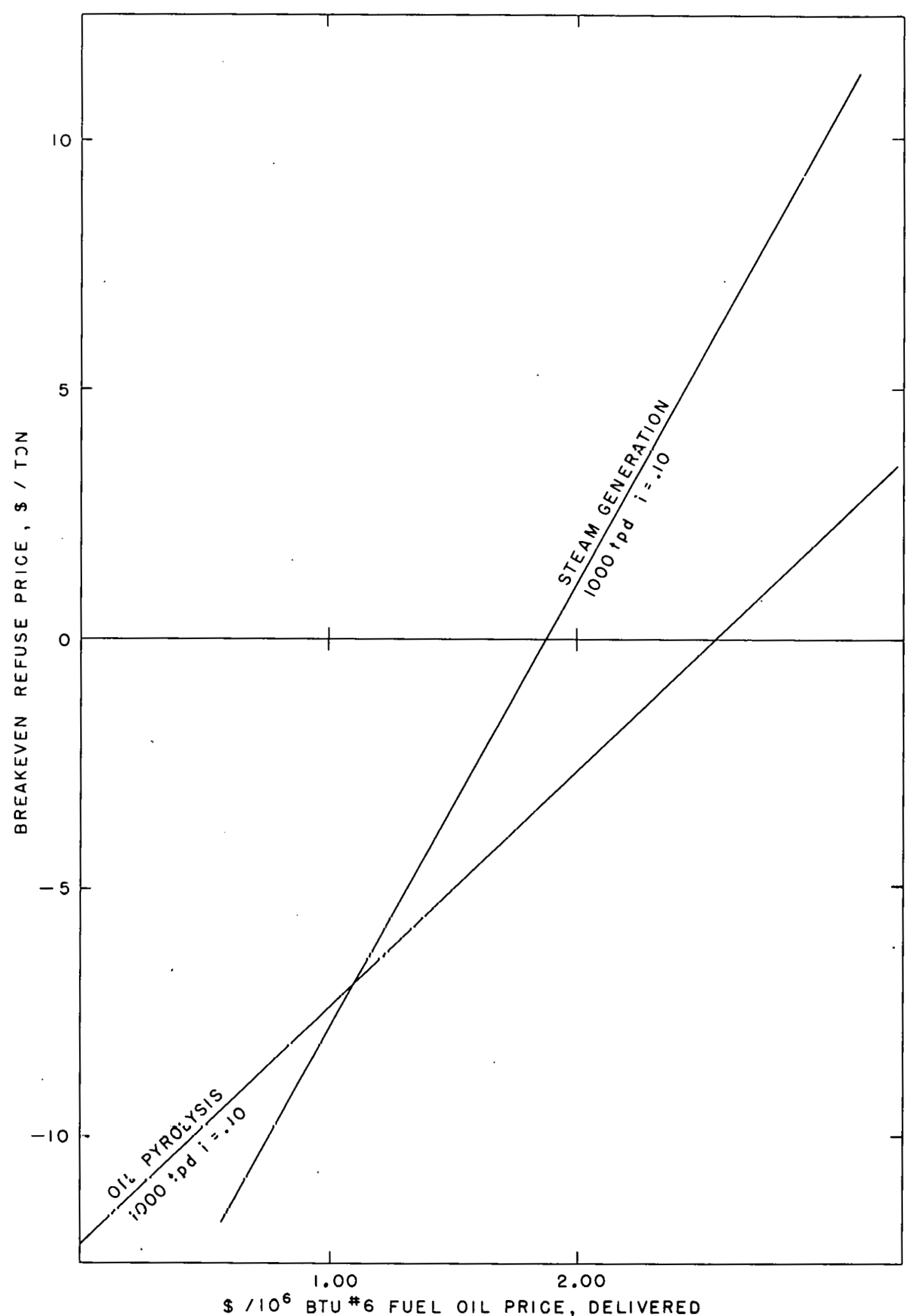

Figure 15. Breakeven refuse price for oil pyrolysis and steam generation. 


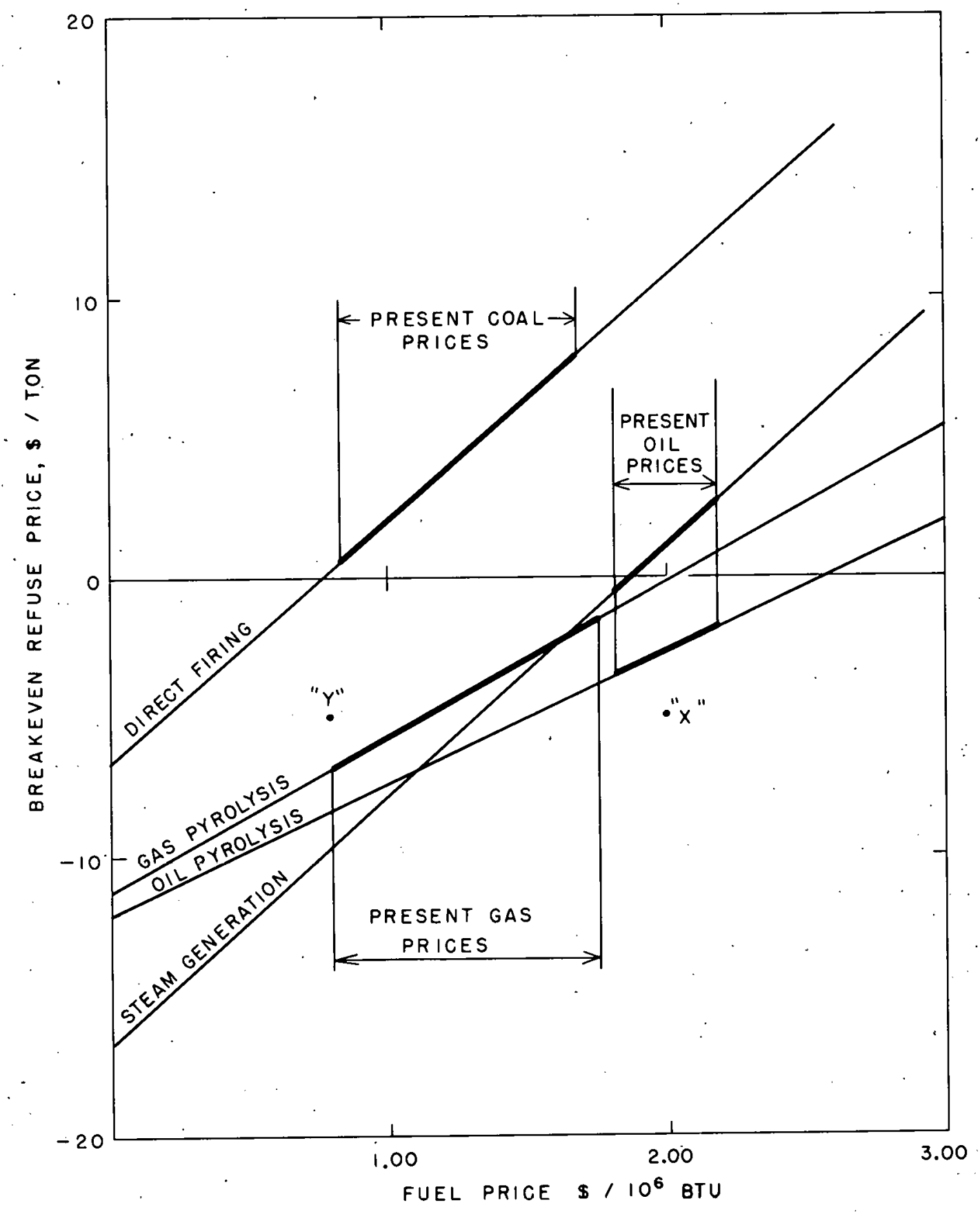

Figure 16. Process comparisons. 
$\$ 2 /$ ton, would find neither pyrolysis process attractive at current energy prices. If there were no haul penalty, however, then the situation would be changed somewhat. Moreover, depending on the interest rate and capacity size, the breakeven refuse price curves shift vertically, which means that the decision problem may be quite complex.

If it is assumed that oil and coal prices will stay at their current levels (in constant dollars) but gas will be deregulated, then a significant rise in gas prices would be expected, particularly in the face of supply shortages in the Northeast. A scenario with gas prices rising to $\$ 2$ to $\$ 3$ per $10^{6}$ Btu would thus appear quite reasonable, and at this point gas pyrolysis or bioconversion would be economic for all but the most severe haul cost penalty. Likely energy conversion scenarios are further discussed in Chapter IX.

\subsection{Haul costs}

Haul cost differentials are due to locational factors: if a refuse-burning utility boiler is further away from the center of population than the alternative disposal site, then an additional haul cost will be incurred. But the haul cost differential favors the energy recovery method if the utility boiler is in or near the center of the city so that it is cheaper for the collection trucks to deliver there than to a landfill, typically on the outskirts of the city.

The problem is complicated by alternative methods of bringing refuse to the energy recovery facility or alternative disposal site. The simplest procedure is for the collection vehicles to be driven directly to the disposal site (leaving all crew but the driver in the collection area, where they might typically be assigned to clean lots or sweep streets until the empty truck returns to continue collection). Alternatively, the collection vehicles are ariven to 
- - or more centrally located transfer stations, and large tractorzilers are used for the trip to the disposal site; this is preferable if the disposal site is far from the central city. Generalized cost functions for these two alternatives are derived in Appendix C.

If one assumes a radially symmetric city with an exponential population density gradient, then direct haul in collection vehicles to a site at distance $l$ from the city center, results in an average haul cost per ton that is a function of the radius, $R$, to which refuse is collected, namely ${ }^{21}$

$$
C_{s}(R)=\frac{\gamma_{h}}{t} \frac{1}{s} \frac{4 \alpha^{2}}{\pi} \frac{\int_{0}^{R} r(r+l) e^{-\alpha r} E\left(\frac{2 \sqrt{r l}}{r+\ell}\right) d r}{1-(I+\alpha R) e^{-\alpha R}}+\frac{\gamma_{h}}{t} u
$$

where $C_{S}(R)=$ average haul cost, $\$ /$ ton, in a city of radius $R$

$$
\begin{aligned}
\gamma_{\mathrm{h}} & =\text { hourly cost of operation of collection vehicle, } \$ \text { /hour } \\
t & =\text { truck capacity, tons } \\
\mathrm{s} & =\text { average truck speed, mph } \\
\alpha & =\text { density gradient of SMSA, mile } \\
\mathrm{u} & =\text { unloading time, in hours } \\
\mathrm{E}(\mathrm{x}) & =\text { a complete elliptical integral of the second } \mathrm{kind} .
\end{aligned}
$$

In the special case of a destination at the city center this can be shown to reduce to 22

$$
C_{s}(R)=\frac{\gamma_{h}}{t} \frac{1}{s} \frac{2}{\alpha}\left[\frac{2-\left(2+2 \alpha R+\alpha^{2}{ }^{2}\right) e^{-\alpha R}}{1-(1+\alpha R) e^{-\alpha R}}\right]+\frac{\gamma_{h}}{t} u
$$

The assumption that population distribution in an urban area is adequately characterized by an exponential decline with distance from the city center is discussed elsewhere. 23 
Alternatively, if a transfer station at a distance $l$ from the city center is used, and with the disposal destination at distance $h$ from the center, the average cost per ton can be shown to be given by 24

$$
\begin{aligned}
c_{s}(R) & =\frac{\gamma_{h}}{t} \frac{1}{s} \frac{4 \alpha^{2}}{\pi} \frac{\int_{0}^{R} r(r+l) e^{-\alpha r} E\left(\frac{2 \sqrt{r l}}{r+l}\right)}{1-(1+\alpha R) e^{-\alpha R}}+\frac{\gamma_{h}}{t} u \\
& +\frac{\gamma^{*}}{t^{*}}\left[\frac{2(h-l)}{s^{*}}+u^{*}\right]+\frac{33.4}{\left[\frac{2 \pi a}{260 u^{2}}\left[1-(1+\alpha R) e^{-\alpha R}\right]\right]^{0.55}}
\end{aligned}
$$

where $\gamma *=$ hourly cost of operating transfer vehicle, $\$ / \mathrm{hr}$

$$
\begin{aligned}
& t^{*}=\text { transfer vehicle capacity, tons } \\
& \mathbf{s}^{*}=\text { transfer vehicle speed, mph } \\
& u^{*}=\text { loading and unloading time, hours }
\end{aligned}
$$

For a given disposal site, Eg. [7] can be used to determine the optimal transfer station location simply by solving for a series of values of $l$. The cost of the optimal transfer system can then be compared with that of the optimal direct haul system computed from Eq. [6], and the lower of the two determines which system is chosen. By carrying out this procedure for hauling both to the energy recovery site and to the conventional disposal site, the. haul penalty is easily determined.

Two points need to be stressed. First, haul cost as defined here includes all costs incurred by the collection vehicles except that during actual house-to-house collection; it thus comprises the costs of travel from the end of a collection route (when the truck is full), to the disposal (or transfer station) site, unloading time, and travel back to the beginning of the next collection route. 
- cond, the procedure outlined above for the determination of haul ist penalty assumes that $R$ is known: in the general case one simply sets $R$ equal to the average radius of the urban area in question, from which the average costs can be computed directly with the above equations. The amount of refuse collected within the radius $\mathrm{R}$ is derived in Appendix $\mathrm{B}$, and can be shown to equal 25

$$
Q(R)=\frac{.1825 q_{0} \alpha_{0}{ }^{1+\beta} \theta}{\alpha^{2}}\left(1-(1+\alpha R) e^{-\alpha R}\right)
$$

where $q_{0}=$ per capita waste generation, $1 \mathrm{bs} / \mathrm{cap} / \mathrm{day}$

$\mathrm{d}_{\mathrm{o}}=$ population density at the city center, persons/sq. mi.

$\beta=$ parameter characteristic of the variation of waste generation with population density

$\theta=$ sector angle (defined in Meier \& McCoy, Note 22)

At this point the breakeven refuse price can be reconsidered. Assume that an urban area has no coal-fired plants and no potential industrial user of process steam. Further, let the price of gas be $80 \% / 10^{6} \mathrm{Btu}$ and of oil $200 \% / 10^{6} \mathrm{Btu}$, and let the alternative disposal cost be $\$ 5 /$ ton, say by sanitary landfill. These two points are shown as $X$ and $Y$ in Figure 16. Since $Y$ lies above the gas pyrolysis curve, the alternative disposal method (landfilling) will be cheaper unless it costs less (by at least $\$ 1.84 /$ ton) to haul refuse to the gas pyrolysis facility than to the landfill. Similarly, oil pyrolysis will be economic only if the haul cost differential is less than about $\$ 2.55 /$ ton.

However, Eqs. [6] and [7] show that the haul cost differential is a function of $R$ (and hence of the amount of refuse delivered to the facility); the average haul cost will increase as refuse is brought in from greater distances. The question is, how much 
refuse in any given area will in fact be converted to energy in that area? It is shown in Appendix $D$ that $R$ is the distance for which the breakeven refuse price plus the alternative disposal cost equals the haul cost; in the simplest case, namely, an energy conversion facility at the city center with direct delivery of refuse in collection vehicles, the optimal distance $R^{*}$ is given by

$$
R *=\frac{t s\left(P_{R}+P_{D}\right)}{2 \gamma_{h}}-\frac{u s}{2}
$$

and the correspondinq quantity of refuse converted to energy is given by

$$
Q\left(R^{*}\right)=\frac{.1825 q_{0} d_{0}^{1+\beta} \theta}{\alpha^{2}}\left(1-\left(1+\alpha R^{*}\right) e^{-\alpha R^{*}}\right)
$$

For typical values of the parameters of Eq. [8], $R^{*}$ can be expressed as a function of $P_{R}$ and $P_{D}$; for example, if $t=5.5$ tons, $s=15 \mathrm{mph}$, $u=.25 \mathrm{hrs}$, and $r_{h}=\$ 20 /$ hour

$$
\begin{aligned}
R^{*} & =\frac{5.5 \times 15}{2 \times 20} P_{R}+\frac{5.5 \times 15}{2 \times 20} P_{D}-\frac{.25 \times 15}{2} \\
& =2.06 P_{R}+2.06 P_{D}-1.875
\end{aligned}
$$

In the decision diagram of Figure 16 , point $X$ is given by $P_{R}=-2.5, P_{D}=5.0$; hence for gas pyrolysis

$$
\begin{aligned}
R^{*} & =-5.15+10.3-1.875 \\
& =3.27 \text { miles }
\end{aligned}
$$


mis is a rather small distance, implying that it would be worthiile to collect the refuse for energy recovery only from the very central part of the city where the population cencentration is high. But if the same town had a coal fired utility boiler, for which $P_{R}$ is $\$ 6 /$ ton, then $R^{*}$ computes to

$$
R^{*}=12.36+10.3-1.875=20.78 \text { miles }
$$

implying that it would be worthwile to go well out to suburbia to collect refuse for burning at a centrally located utility boiler.

\subsection{Results for Northeastern SMSA's}

The preceding analysis has been considerably simplified in order to illustrate the principles involved. Two major simplifications need be addressed. First, it was assumed in Eq. [9] that $P_{R}$ is constant; but it was stated previously that $P_{R}$ is a function of scale economies. In fact, Eq. [3] should be substituted into Eq. [8] to yield

$$
\begin{aligned}
R^{*}=\frac{t s}{2 \gamma_{h}} & \left.\mid P_{E} E-O^{\prime}-\operatorname{CRF}(i, n)\left[\frac{I^{\prime}\left(q_{O}\right)}{q_{O}{ }^{b-1}}\right] Q\left(R^{*} .\right)^{b-1}\right\} \\
& +\frac{t s}{2 r_{h}} P_{D}-\frac{u s}{2} .
\end{aligned}
$$

which must be solved simultaneously with Eq. [9].

The second assumption, implicit in the derivation of Eq. [8] in Appendix D, is that there is no haul cost for refuse not delivered to the energy recovery facility, i.e., for refuse generated beyond the distance $R^{*}$. This assumption is not unrealistic if $R^{*}$ is larger than the radius of the central city. In the typical urban area of the Northeast, municipal house-to-house collection exists only in the central city; in the suburbs disposal is by individuals 
delivering to a landfill or by private contractors on an ad hoc basis. Since the disposal sites in the typical suburb tend to lie within that suburb, haul costs (as defined here) tend to be low.

Since efficient refuse collection exists primarily in urban areas, the SMSA (standard metropolitan statistical area) is used here as the basis for detailed estimates of parameters of refuseto-energy conversion. Tables 9 through 12 show the optimum collection radius $\mathrm{R}^{*}$ for all Northeastern SMSAs and all non-SMSA urbanized areas of more than 25,000 population. Tables 9 and 10 show the 1972 base year results for direct refuse firing in a centrally located utility boiler, for an alternative disposal cost of $\$ 5$ and $\$ 15 /$ ton, respectively, corresponding to landfill and incineration disposal. Tables 11 and 12 give similar data for gas conversion (pyrolysis or bioconversion).

Several conclusions can be drawn from these tables. Note, first, that the optimal radius exceeds the SMSA radius in all cases for direct firing at an alternative disposal cost of $\$ 15.00 /$ ton (Table 10). This implies that it would be worth while to burn all of the refuse generated in these areas. If the alternative disposal cost falls to $\$ 5.00 /$ ton (Table 9) the optimal recovery radius for some SMSA's (marked with an $\mathrm{X}$ ) is less than the SMSA radius which implies that only part of the SMSA would be included in an energy recovery project. Note that the optimal radius is greater than the central city radius $(\mathrm{R}-\mathrm{CC})$, as indicated in the earlier discussion.

Table 11 shows that gas pyrolysis would not be economic in any SMSA if the alternative disposal cost is $\$ 5.00 /$ ton. However, if it rises to $\$ 15.00 /$ ton (Table 12 ), only those SMSAs (marked $\mathrm{X}$ ) for which the optimum radius is less than the SMSA radius would not include all refuse in a recovery system. 
OPTIMUM RADIUS FOR ALTERNATIVE DISPOSAL AT $\$ 5.00 /$ TON

LIFECT FIFING IN UTILITY MOILERS, PE=COAL PRICE, $\$ / T O N$

\begin{tabular}{|c|c|c|c|c|c|}
\hline SMSA $\cdot{ }^{\prime}$ & $R^{*}$ & R-SMSA & $0-c c$ & $P R$ & $P E$ \\
\hline ALBNY SCHEN & $20.5 x$ & 26.6 & 3.6 & 3.3 & 28.0 \\
\hline ALLNTWN BET & $16.0 \times$ & 18.6 & 3.7 & 1.2 & 22.0 \\
\hline ALTOONA & 14.6 & 13.0 & 1.7 & 1.2 & 22.0 \\
\hline ATLANTIC CIT & 33.1 & 19.0 & 2.8 & 8.0 & 41.0 \\
\hline BALTIHORE & $80, p \times$ & 35.1 & 6.5 & 6.9 & 38.0 \\
\hline BINGHAMPTON & $20.5 x$ & 25.7 & 1.9 & 3.3 & 28.0 \\
\hline BOSTON & 24.4 & 19.9 & 4.3 & 4.8 & 32.0 \\
\hline SRI OCEPOFT T & 24.4 & 11.1 & $2 \cdot 3$ & 4.3 & 32.0 \\
\hline BRISTOL & 24.4 & 4.0 & 2.9 & 4.8 & 32.0 \\
\hline BROCXION & 24.4 & 7.2 & 2.6 & 4.8 & $3 ? .0$ \\
\hline $\begin{array}{l}\text { BUFFALO } \\
\text { ERIE }\end{array}$ & $\begin{array}{l}20.5 \times \\
14.6 \times\end{array}$ & $\begin{array}{l}26.0 \\
22.8\end{array}$ & $\begin{array}{l}4.2 \\
2.5\end{array}$ & $\begin{array}{l}3.3 \\
1.2\end{array}$ & 28.0 \\
\hline FALL FIVER & 24.6 & 13.5 & 3.2 & $\begin{array}{l}1.8 \\
4.8\end{array}$ & $\begin{array}{l}22.0 \\
32.0\end{array}$ \\
\hline FITCH LEO & 24.4 & 7.3 & 6.2 & 4.8 & 32.0 \\
\hline $\begin{array}{l}\text { WAFR I SBUPG } \\
\text { HARTFORO }\end{array}$ & $14.6 \times$ & 32.2 & 1.5 & 1.2 & 22.0 \\
\hline $\begin{array}{l}\text { HARTFORO } \\
\text { JERSEY CITY }\end{array}$ & 24.4 & 16.6 & $2: 4$ & 4.8 & 32.0 \\
\hline $\begin{array}{l}\text { JERSEY CITY } \\
\text { JOHNSTOHN }\end{array}$ & 33.1 & 5.5 & 3.1 & 8.0 & 41.0 \\
\hline $\begin{array}{l}\text { JOHNSTOHN } \\
\text { LANCASTER }\end{array}$ & $1+.0 \times$ & 23.8 & 1.4 & 1.2 & 22.0 \\
\hline $\begin{array}{l}\text { LANCASTER } \\
\text { LAHFHAVERHIL }\end{array}$ & $14.6 \times$ & 17.4 & 1.5 & 1.2 & 22.0 \\
\hline $\begin{array}{l}\text { LAWFHAVERHIL } \\
\text { LEWIS } \approx A \cup B U R N\end{array}$ & 24.4 & 0.1 & 3.5 & 4.8 & 32.0 \\
\hline LEWIS XAUBURN & 24.4 & 6.1 & 3.3 & 4.8 & 32.0 \\
\hline $\begin{array}{l}\text { LOWELL } \\
\text { MANCHESTER }\end{array}$ & 24.4 & 7.0 & 2.1 & 4.8 & 32.0 \\
\hline $\begin{array}{l}\text { MANCHESTER } \\
\text { MERIOFN }\end{array}$ & 24.4 & 6.7 & 3.2 & 4.8 & 32.0 \\
\hline $\begin{array}{l}\text { MERIOFN } \\
\text { NASHUA }\end{array}$ & 2.8 & 2.8 & 2.8 & 4.8 & 32.0 \\
\hline $\begin{array}{l}\text { NASHUA } \\
\text { N. SECF ORO }\end{array}$ & 3.3 & 3.3 & 3.2 & 4.8 & 32.0 \\
\hline $\begin{array}{l}\text { N. BECF ORO } \\
\text { N.BRITAIN }\end{array}$ & 24.4 & 6.7 & 2.5 & 4.8 & 32,0 \\
\hline $\begin{array}{l}\text { N.BRITAIN } \\
\text { N.HAVEN }\end{array}$ & 24.4 & 5.3 & 2.1 & 4.8 & 32.0 \\
\hline $\begin{array}{l}\text { N. HAVEN } \\
\text { N.LNONEGRTNE }\end{array}$ & 24.4 & 9.1 & 2.5 & 4.8 & 32.0 \\
\hline $\begin{array}{l}\text { N. LNONEGRTNE } \\
\text { N. YORK }\end{array}$ & 24.4 & 10.9 & 3.2 & 4.8 & 32.0 \\
\hline $\begin{array}{l}\text { N. YORK } \\
\text { NEWARK }\end{array}$ & $20.5 \times$ & .36 .9 & 13.9 & 3.3 & 28.0 \\
\hline $\begin{array}{l}\text { NE HARK } \\
\text { NORHALK }\end{array}$ & $3 \geq \cdot 1$ & 14.9 & 2.7 & 0.0 & 41.0 \\
\hline PTRSNFCLIFTE & $\begin{array}{l}24.6 \\
33.1\end{array}$ & $\begin{array}{r}5.6 \\
23.3\end{array}$ & $\begin{array}{l}3.7 \\
2.7\end{array}$ & $\begin{array}{l}4.8 \\
8.0\end{array}$ & 32.0 \\
\hline PHILACELPHIA & $14.6 x$ & 33.6 & 6.4 & $\begin{array}{l}0.0 \\
1.2\end{array}$ & 22.0 \\
\hline PIITSAURG & $14.6 \times$ & 31.2 & 4.2 & 1.2 & 22.0 \\
\hline PITTSFIELO & 24.4 & 6.7 & 3.5 & 4.8 & 32.0 \\
\hline $\begin{array}{l}\text { PORTL AND } \\
\text { PO OVDNC \&PAHE }\end{array}$ & 26.6 & 10.6 & 3.2 & 4.8 & 32.0 \\
\hline PO OVDNC XPAHE & 24.4 & 15.1 & 4.6 & 4.8 & 32.0 \\
\hline READING & $14.6 \times$ & 16.6 & 1.8 & 1.2 & 22.0 \\
\hline ROCHESTER & $20.5 x$ & $3 E .4$ & 4.6 & 3.3 & 28.0 \\
\hline $\begin{array}{l}\text { SCRANTON } \\
\text { SPFD } \$ \text { OLL } ¥ C H I\end{array}$ & $1+.6$ & 12.0 & 2.9 & 1.2 & 22.0 \\
\hline $\begin{array}{l}\text { SPFDXHOL } F C H I \\
\text { STAMFORO }\end{array}$ & 24.6 & 13.0 & 4.9 & 4.8 & 32.0 \\
\hline STAMFORO & 24.6 & $e .8$ & 4.9 & 4.8 & 32.0 \\
\hline SYRACUSE & $20.5 \times$ & 27.8 & 2.9 & 3.3 & 28.0 \\
\hline TRENTCN & 33.1 & 12.1 & 2.2 & 8.0 & 41.0 \\
\hline UT I CA $\triangle R O M E$ & $20.5 x$ & 29.1 & 5.3 & 3.3 & 28.0 \\
\hline VINELANO & 35.1 & 12.6 & 4.7 & 8.0 & 41.0 \\
\hline WASHINCTON & $22.4 \times$ & 27.4 & 4.4 & 4.1 & 30.0 \\
\hline WATERBURY & $24.4^{\circ}$ & 8.3 & 3.0 & 4.8 & 32.0 \\
\hline WLKSABAAHAZE & $14.6 \times$ & 16.8 & 2.0 & 1.2 & 22.0 \\
\hline NIL NINETON & $15.6 \times$ & 27.2 & 2.0 & 1.6 & 23.0 \\
\hline WOPCESIER & 24.4 & 12.3 & 3.5 & 4.8 & 32.0 \\
\hline YOKK & $14.6 \times$ & 21.4 & 1.3 & 1.2 & 22.0 \\
\hline BUFLING TONI* & 24.4 & 18.4 & 1.8 & 4.8 & 32.0 \\
\hline NE WPORT $1=1$ & 24.4 & 12.1 & 2.2 & 4.8 & 32.0 \\
\hline $\begin{array}{l}\text { NEHCASTLE 1*J } \\
\text { STATE COLLE'G }\end{array}$ & 14.6 & 10.8 & 1.5 & 1.2 & 22.0 \\
\hline $\begin{array}{l}\text { STATE COLLEE } \\
\text { WILLIANSPORT }\end{array}$ & $14.6 \times$ & 18.3 & 1.2 & 1.2 & 22.0 \\
\hline $\begin{array}{l}\text { WILLIANSPORT } \\
\text { LEBANON } 1 * 1\end{array}$ & $14.6 \times$ & 19.7 & 1.7 & 1.2 & 22.0 \\
\hline & $\begin{array}{r}16.6 \\
4.04\end{array}$ & 10.6 & $\begin{array}{l}1.2 \\
3.7\end{array}$ & 1.2 & $22 \cdot \theta$ \\
\hline $\begin{array}{l}\text { DANBUEY } \\
\text { JAMESTOWNC }=1\end{array}$ & 20.5 & $\begin{array}{r}4.4 \\
18.6\end{array}$ & $\begin{array}{l}3.7 \\
1.7\end{array}$ & $\begin{array}{r}4.8 \\
-3.3\end{array}$ & $32: 0$ \\
\hline ELMIDAI $(*)$ & 20.5 & 11.5 & 1.5 & 3.3 & 28.0 \\
\hline ITHACA I-I & 20.5 & 12.4 & 1.3 & 3.3 & 28.0 \\
\hline AURURN $(\bullet)$ & 20.5 & 14.9 & 1.6 & 3.3 & $2 e .0$ \\
\hline ANSTEROAHAT) & 80.5 & 11.4 & 1.4 & 3.2 & 30.0 \\
\hline HOTERTOHN1*1) & 20.5 & $2 i .3$ & 1.7 & 3.3 & 28,0 \\
\hline KINGSTONI+I & 20.5 & 19.1 & 1.6 & 3.3 & 20.0 \\
\hline NENBURGH $(*)$. & 20.5 & $16 \cdot 3$ & 1.1 & 3.3 & 28.0 \\
\hline POUGHKEEPSIE & $20.5 \times$ & 22.8 & 1.8 & 3.3 & 28.0 \\
\hline LONG ERANCHI & 33.1 & 12.3 & 1.3 & 8.0 & 41.0 \\
\hline NOXPERTHXSAY & 33.1 & 10.0 & 2.9 & 8.0 & $+1, \theta$ \\
\hline CONCOROCHA & 24.4 & 17.2 & 4.5 & 4.8 & 32.0 \\
\hline F.1, QUCESTER * * & 43.4 & 43.4 & 9.7 & 4.8 & 32.0 \\
\hline HAGERSIOWN & 30.2 & 12.0 & 1.6 & 6.9 & 38.0 \\
\hline CUMBE KLANC \&" & 30.2 & $1 \epsilon .5$ & 2.3 & 6.9 & 36.0 \\
\hline BANGOR $(\bullet)$ & $24.4 x$ & 32.9 & 3.3 & 4.8 & 32.0 \\
\hline 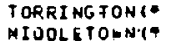 & $\begin{array}{l}24.4 \\
24.4\end{array}$ & 47.2 & 3.6 & 4.8 & 32.0 \\
\hline MIUOLETORNG & $\begin{array}{ll}24.4 \\
-2 .-2-0\end{array}$ & -1 & $\therefore .7$ & $4: 8$ & 32,0 \\
\hline
\end{tabular}

Haul Cost Parameters

Truck size, tons $(t)=5.50$

Unload time, hr (u) $=0.25$

Average speed $\mathrm{mph}(\mathrm{s})=20.00$

Optimum cost, $\$ / \mathrm{hr}\left(\gamma_{h}\right)=20.00$ 
Table 10

OPTIMUM RADIUS FOR ALTERNATIVE

DISPOSAL AT $\$ 15.00 /$ TON

DIRECT FIRING IN UTILITY SOILERS, PEECOAL PRICE,SITON

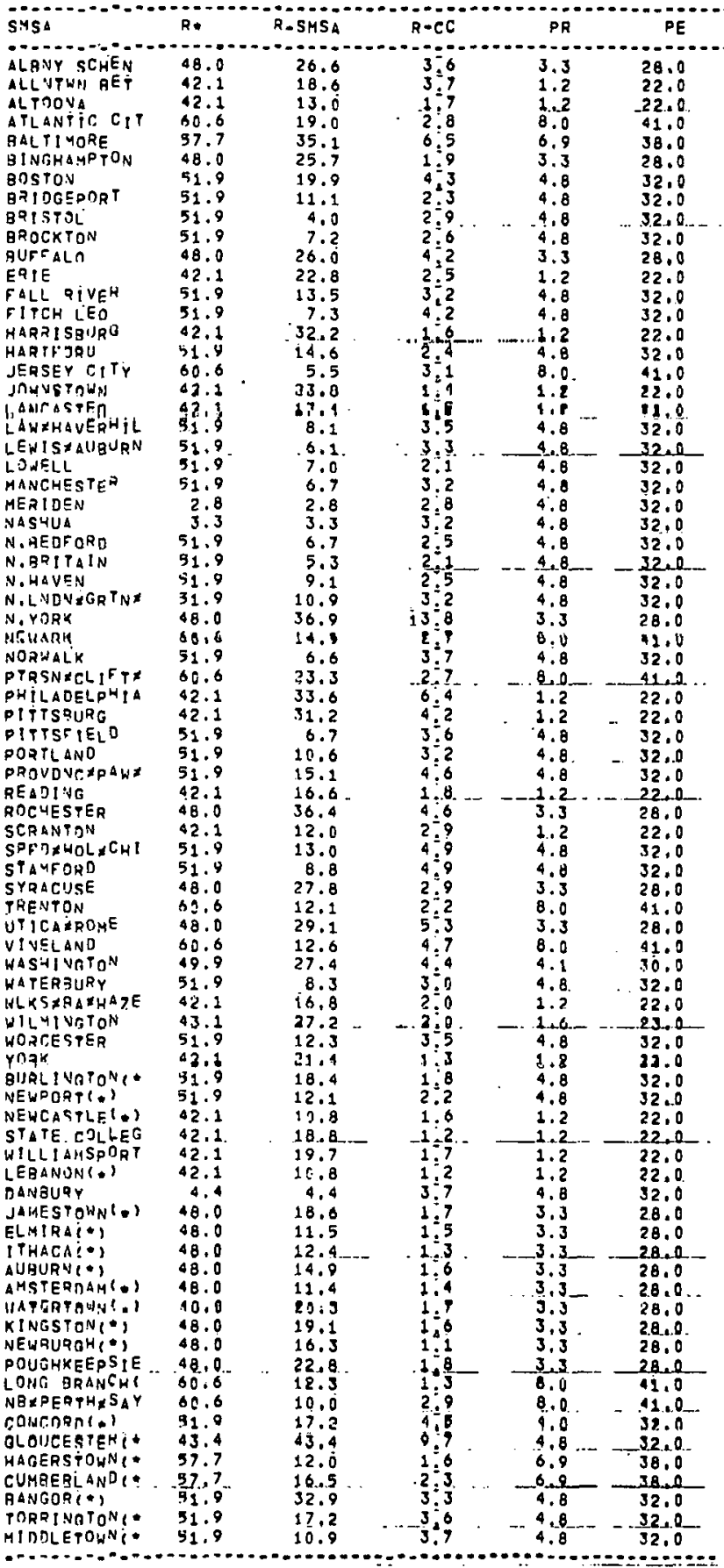

Note: For haul cost parameters

see Table 9 . 
Table 11

OPTIMUM RADIUS FOR ALTERNATIVE DISPOSAL AT $\$ 5.00 /$ TON

GAS PYRULYSIS, PEEGAS PRICE, SIMCF

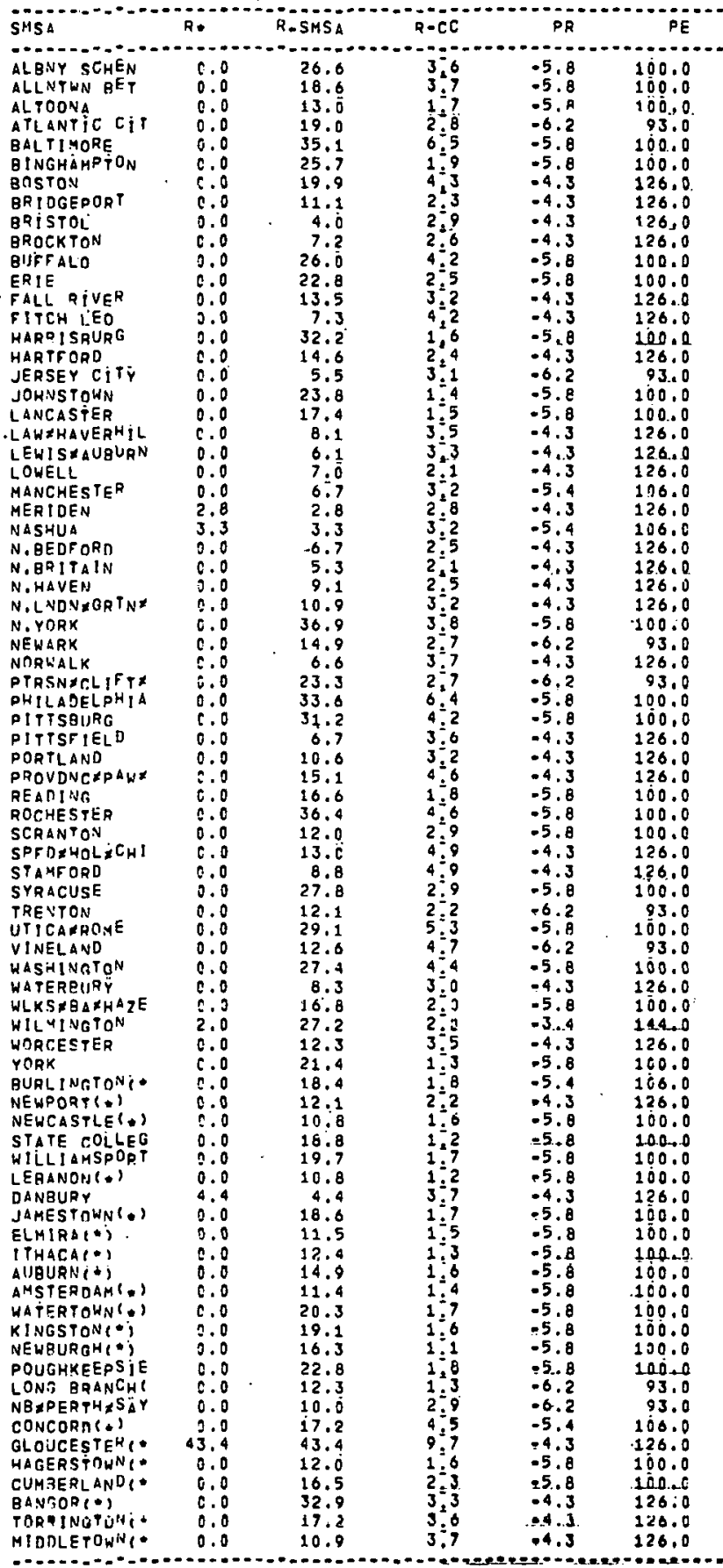

Note: See Table 9 for haul cost parameters. 
Table 12

OPTIMUM RADIUS FOR ALTERNATIVE DISPOSAL AT $\$ 15.00 / T O N$

\begin{tabular}{|c|c|c|c|c|c|}
\hline SMSA & D. & P.SMSA & $P-C C$ & $P R$ & PE \\
\hline $\begin{array}{l}\text { ALBNY SCHEN } \\
\text { ALLNT WN BET } \\
\text { ALTOONA }\end{array}$ & $\begin{array}{l}22.9 \times \\
22.9 \\
22.9\end{array}$ & $\begin{array}{l}26.5 \\
18.6 \\
13.0\end{array}$ & $\begin{array}{l}8.6 \\
3.7 \\
1.7\end{array}$ & $\begin{array}{l}-5.8 \\
-5.8 \\
-5.8\end{array}$ & $\begin{array}{l}100.0 \\
100.0 \\
100.0\end{array}$ \\
\hline $\begin{array}{l}\text { ATLANTIC CIT } \\
\text { BALTI MOP.F. }\end{array}$ & $22.9 \times$ & $\begin{array}{l}19.0 \\
35.1\end{array}$ & $\begin{array}{l}2.4 \\
6.5\end{array}$ & $\begin{array}{r}-5 . .2 \\
-5.8\end{array}$ & $\begin{array}{r}93.0 \\
100.0\end{array}$ \\
\hline BINGHAMPTON & $22.9 \times$ & 25.7 & 1.9 & -5.9 & 100.0 \\
\hline BOSTON & 26.0 & 19.9 & 6.3 & -4.3 & $12 \mathrm{E} .0$ \\
\hline $\begin{array}{l}\text { BRI IOGEP ORT } \\
\text { BR ISTOL }\end{array}$ & $\begin{array}{l}26.3 \\
26.8\end{array}$ & $\begin{array}{r}11.1 \\
4.0\end{array}$ & $\begin{array}{l}2.3 \\
2.9\end{array}$ & $\begin{array}{l}-4.3 \\
--5.3\end{array}$ & $\begin{array}{l}12 E .0 \\
126.0\end{array}$ \\
\hline EROCKTON & $25: 8--$ & (7) & 2.6 & --2.3. & $226=0$ \\
\hline BUFFALO & $22.9 \times$ & $2 \epsilon .0$ & 4.2 & -5.8 & 100.0 \\
\hline ERIE & 22.9 & 22.8 & 2.5 & -5.8 & 100.0 \\
\hline FALL RIVER & 26.8 & $\$ 3.5$ & 3.2 & -4.3 & 126.0 \\
\hline $\begin{array}{l}\text { FITCH LEO } \\
\text { HARKISSURG }\end{array}$ & $\begin{array}{l}26.8 \\
20.9 \times\end{array}$ & $\begin{array}{r}7.3 \\
32.2\end{array}$ & $\begin{array}{l}4.2 \\
1.5\end{array}$ & $\begin{array}{l}-4.3 \\
-5.8\end{array}$ & $\begin{array}{l}126.0 \\
106.0\end{array}$ \\
\hline PATIFORE - & 26.8 & -15.5. & $2.4 \%$ & $\cdots=0.5 \cdots$ & $126.0 \cdots$ \\
\hline JEKSEY CITY & 21.8 & 5.5 & 3.1 & -6.2 & 93.0 \\
\hline JORNSTIAN & $22 \cdot .9 \times x$ & 23.8 & 1.4 & -5.8 & 100.0 \\
\hline LANCASTER & 22.9 & 17.6 & 1.5 & -5.8 & 100.0 \\
\hline $\begin{array}{l}\text { LAWZHAVERHIL } \\
\text { LEWIS } \triangle A \text { UBURN }\end{array}$ & $\begin{array}{l}26.3 \\
26.8\end{array}$ & $\begin{array}{l}8.1 \\
6.1\end{array}$ & $\begin{array}{l}3.5 \\
2.3\end{array}$ & $\begin{array}{l}-\dot{-} .3 \\
-6.3\end{array}$ & 126.0 \\
\hline Lntret. & $76 . K$ & 7.11 & $7.7-$ & $=6.3^{-}$ & -TPF:n \\
\hline MGNCHF STFR & 23.8 & 6.7 & $3 . ?$ & $=5.6$ & Inf.n \\
\hline rERIOEN & 2.8 & 2.8 & 2.8 & -4.3 & 126.0 \\
\hline NASHUA & $3 . x$ & 3.3 & 3.2 & $-5 . \div$ & $16 E .0$ \\
\hline N. EEOFORD & 25.8 & 6.7 & 7.5 & -4.3 & $12 F .0$ \\
\hline N. ARITAIN & 216.8 & 5.3 & 2.1 & $-4,3$ & 126.0 \\
\hline T: TRVET & $20.8-1$ & $3.1-$ & $2: 3-$ & $=7: 35$ & $728: 0$ \\
\hline N.L NUNHCOFNT & 25.8 & 16.9 & 3.2 & -4.5 & 126.0 \\
\hline N. YOPK & $22.9 \cdot x$ & 36.9 & 13.8 & $-E, B$ & 130.0 \\
\hline NEHARK & 21.3 & 14.9 & 2.7 & -5.2 & 93.0 \\
\hline NORHALK & $26: 8$ & 6.6 & 3.7 & -2.3 & 126.0 \\
\hline 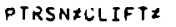 & $21.8 \times$ & 23.3 & 2.7 & -6.2 & 93.0 \\
\hline PHITALELPRIA & $22.9 \times$ & 33.6 & $6: \div$ & $=5.8^{-}$ & $-100 \div 0^{-}$ \\
\hline PITTSDURG & $22.9 x$ & 31.2 & 4.2 & -5.8 & 100.0 \\
\hline DITTSFIELO & $2 E \cdot B$ & 6.7 & 3.6 & -4.3 & 126.0 \\
\hline POFTLAND & 26.8 & 10.6 & 3.2 & -4.3 & 126.0 \\
\hline PFOVONEXPAHE & 26.8 & 15.1 & 4.6 & -4.3 & $12 € .0$ \\
\hline FEAOING & 22.9 & 16.6 & 1.8 & -5.8 & 100.0 \\
\hline FOCHESTEF & $.22 .9 x$ & JE. 4 & -6.5 & $=5.8$ & $100.0^{\circ}$ \\
\hline $\begin{array}{l}\text { SCRANTON } \\
\text { SPFOEHOL }\end{array}$ & 22.9 & 12.0 & 2.9 & $\begin{array}{l}-5.8 \\
-4.3\end{array}$ & 100.0 \\
\hline SPFOXHOL XCHI & 26.8 & 13.0 & 4.9 & -4.3 & 126.0 \\
\hline STA MF ORD & 26.9 & 8.8 & 4.9 & -4.3 & 126.0 \\
\hline SYFACUSE & $22.9 x$ & 27.8 & 2.9 & -5.8 & 100.0 \\
\hline TRENTON & 21.8 & 12.1 & 2.2 & -6.2 & 93.0 \\
\hline UTICAXROME & $22.9 x$ & 29.1 & 5.3 & -5.8 & 100.0 \\
\hline VI NCL AND & $21.8^{\circ}$ & 12.6 & 4.7 & -6.2 & 93.0 \\
\hline HASHING TON & $22.9 \times$ & 27.4 & 4.4 & -5.8 & 100.0 \\
\hline WATERBURY & 26.8 & 8.3 & 3.0 & -4.3 & 126.0 \\
\hline WLKS $\ E A \triangle H A Z E$ & 22.9 & 16.9 & C. D & -5.8 & 100.0 \\
\hline WILMINGTON & $29.3 x$ & 27.2 & 2.0 & -3.4 & 144.0 \\
\hline WORCESTER & -26.8 & 12.3 & 3.5 & $=6.3$ & $-126: 1$ \\
\hline YORK & 22.9 & 21.4 & 1.3 & -5.8 & 100.0 \\
\hline BURLING TON 1 * & 23.8 & $18 \ldots$ & 1.8 & -5.4 & $10 E .0$ \\
\hline NFWPODTIFI & $? 5, \mathrm{R}$ & 12.1 & $P, 2$ & $=4.3$ & 126.7 \\
\hline NEHCASTLE(*) & 22.9 & 10.8 & 1.6 & -5.8 & 100.0 \\
\hline ETATR COLLEE & 22.7 & 18.8 & ใ. & $\cdot r_{2} .8$ & 100.6 \\
\hline DICLIAMSPORT & 22.9 & T9. & 1.7 & $=5.8$ & 100.0 \\
\hline LEBANON (*) & 22.9 & 10.8 & 1.2 & -5.8 & 100.0 \\
\hline DONAURY & 4.7 & 4.6 & 3.7 & -6.3 & $12 \mathrm{~F} .0$ \\
\hline JAMESTOHN $(*)$ & 22.9 & 18.6 & 1.7 & -5.8 & 100.0 \\
\hline ELHIKA(*) & 22.9 & 11.5 & 1.5 & -5.8 & 100.0 \\
\hline ITHACA $1 * 1$ & 22.9 & 12.4 & 1.3 & -5.8 & 100.0 \\
\hline AUBURNT TT - & 22.4 & 14.9 & $T . E$ & $=5.8$ & 100.0 \\
\hline $\begin{array}{l}\text { AHSTEROAM } 1 * 1 \\
\text { HATERTOHN }\end{array}$ & 22.9 & 11.4 & 1.4 & $\begin{array}{l}-5.8 \\
-5.8\end{array}$ & 100.0 \\
\hline $\begin{array}{l}\text { HATERTOHN (*) } \\
\text { KINGSTON }(*)\end{array}$ & $\begin{array}{l}22.9 \\
22.9\end{array}$ & 19.1 & $\begin{array}{l}1.7 \\
1.5\end{array}$ & $\begin{array}{l}-5.8 \\
-5.8\end{array}$ & $\begin{array}{l}100.0 \\
100.0\end{array}$ \\
\hline NEKBUFGH (*) & 23.9 & $16.3^{\circ}$ & 1.1 & -5.8 & 100.0 \\
\hline POUGHKESPSIE & 22.9 & 22.8 & 1.8 & -5.8 & 100.0 \\
\hline $\begin{array}{l}\text { LOTIO ORATEHT } \\
\text { NBXPEFTH\#SAY }\end{array}$ & $\begin{array}{l}21.0 \\
21.8\end{array}$ & $\begin{array}{l}10.5 \\
10.0\end{array}$ & $\begin{array}{l}175 \\
2.9\end{array}$ & $\begin{array}{l}0.18 \\
-6.2\end{array}$ & $\begin{array}{l}93.0 \\
93.0\end{array}$ \\
\hline CONCORCI=1 & 23.8 & $17: 2$ & 4.5 & -5.6 & 106.0 \\
\hline GLOUCESTERI* & +3.4 & 43.4 & 9.7 & -4.3 & 126.0 \\
\hline HAGERSTOWNIF & $-22: 9$ & $12: 0$ & 1.8 & -5.8 & 100.0 \\
\hline CUKBE PLAND I* & 22.9 & 16.5 & 2.3 & -5.8 & 100.0 \\
\hline ENRTSOOTI & $26.8 \times$ & 37.9 & $73^{2}$ & $=\pi .3$ & 126.0 \\
\hline TOREING TONI* & $26 . d$ & $1 \% .2$ & 3.6 & -4.3 & 126.0 \\
\hline MIDOLE TOWN S $^{*}$ & 26.8 & 16.9 & 3.7 & -4.3 & 126.0 \\
\hline
\end{tabular}

Note: See Table 9 for haul cost parameters. 
In summary, any urban area that has a coal-fired utility boiler hin its radius should find it economic to dispose of its refuse by direct firing. If the alternative disposal method is sanitary landfill, some cities would find it economic to burn only part of their refuse at a utility boiler, but in all cases it appears that some part of urban refuse could be fired economically. Gas pyrolysis by either bioconversion or the Garrett process appears economic only if incineration is the alternative disposal method.

\subsection{A Caveat}

The results of this section, whatever their validity at a regional scale, must obviously be interpreted with some caution at the local level. The conclusion, for example, that firing of refuse as a supplementary fuel at coal-firing boilers appears on the basis of a strictly economic analysis to be the optimal choice does not imply that every utility would or should take this course. Obviously, some Northeastern utilities currently have no coal-fired plants nor have they plans to convert from oil to coal; ${ }^{26}$ and surely our conclusion should not be taken as a recommendation that such utilities immediately make radical changes in their generation mix in order to utilize any available refuse. By the same token, many mine-mouth plants in western Pennsylvania are quite remote from the urban areas where most refuse is generated, and again we do not imply that refuse should be hauled uneconomic distances. The type of regional assessment undertaken here obviously is no substitute for case-by-case engineering analysis; yet, in the absence of such studies for each locality, regional analysis demands that certain generalizations be made if the effort of analysis is to be kept within reasonable bounds. 
1. Midwest Research Institute, "Resource Recovery: The State of Technology", Report to the Council on Environmental Quality, Feb. 1973.

2. See below, chapter VI.

3. See e.g., F. A. Holland, F. A. Watson, and J. K. Wilkinson, "How to Estimate Capital Costs", Chemical Engineering, April 1 , 1974 , p. 71 .

4. Ibid, p. $73-74$

5. As tabulated in recent issues of Chemical Engineering.

6. This assumption is not as unreasonable as may appear, because the agreements between entrepeneur and municipality typically span 15 to 25 years, guaranteeing supply arrangements and delivery prices over that time span. (See also Chapter VI, bebw).

7. In fact, a plot of $P_{R}$ against $Q_{R}$ would slope upwards rather than downwards.

8. See e.g., Horner \& Shifrin, "Solid Waste as a fuel for Power Plants". U. S. EPA, 1973 (Published by NTIS, PB 220 316).

9. FPC, "Steam-Electric Plant Construction Cost \& Annual Production Expenses", 25th Annual Suppl. - 1972, p. 84.

10. FPC News, Vol. 8, No. 37, (Sept. 12, 1975), p. 11.

11. Spot prices for the same period were between $\$ 2$ and $\$ 4 /$ ton higher.

12. H. W. Schulz, "Cost/Benefits of Solid Waste Refuse", Environmental Science \& Technology, Vol. 9, No. 5, p. 423 (May 1975).

13. R. N. Langlois, A Perspective on the Energy Future of the Northeast: Natural Gas Supply, BNL 50558, Sept. 1975.

14. FPC News, Vol. 8, No. 38, p. $24,32$.

15. Ibid, p. 18 .

16 See above, Section 3.3 
1. Midwest Research Institute, Note 1, supra, at p. 40.

18. "Refuse to Energy Plant Uses. First Von Roll Incinerators in U. S.", Environmental Science \& Technology, Vol. 8, No. 8, p. 693 (Aug. 1974).

19. Assuming a standard industrial work week of six 24 hour days, as used, for example, in Midwest Research Institute, Note I, supra.

20. The validity of this figure is evident also from Figure 16; if one assumes no energy recovery from the Von Roll incinerator equivalent to a zero fuel price, then the applicable breakeven refuse price is seen to lie at around $\$ 17 /$ ton, namely the intercept of the steam generation breakeven price curve.

21. Appendix C, Eq. [21].

22. Appendix C, Eq. [ 18].

23. P. M. Meier and T. H. McCoy, "An Analytical Approach to the Determination of Urban Population Density Gradients and its application to Energy Planning Problems," BNL 20916 (Jan. 1976), Policy Analysis Division, Brookhaven National Laboratory.

24. Appendix C, Equation [22].

25. Appendix Bं, Equation [14].

26. Long Island Lighting Company, for example, has no coal fired generating facility. 
THIS PAGE

\section{WAS INTENTIONALLY \\ LEFT BLANK}


CHAPTER VI

INSTITUTIONAL CONSTRAINTS

A number of institutional constraints hinder implementation of energy recovery from solid waste, particularly statutory provisions that impede a desired course of resource recovery. However, a municipality that can demonstrate resource recovery to be economically and environmentally attractive in solid waste management can generally muster the political support necessary to remove statutory obstacles. A good example is Nashville, Tennessee: preliminary investigation of the district heating comcept for publicly owned downtown buildings showed that local gas and electric utilities did not have authority under the metropolitan charter to build or operate such a facility; therefore, a new organization, the Nashville Thermal Transfer Corporation, was chartered under Tennessee law in May $1970^{l}$ and given the power to issue revenue bonds for construction.

A major difficulty is that in many cases municipal and county authorities are constrained by law from negotiating contracts that extend beyond the term of the incumbent administration. Yet private enterprise cannot be expected to assume the risk of investing its capital without the protertion of long-term contracts to recover the investment and earn a reasonable profit. Utilities, for example, are accustomed to long-term contracts with their fuel suppliers. However, such obstacles can be easily bypassed, as witnessed by recent logislation in connecticut. which established a Resources Recovery Authority expressly empowered to neyutiato lnng-term contracts for the entrepreneurial manayement of publicly owned resource recovery facilities. 
Other difficulties are less easily overcome. A utility, before it modifies its boilers for supplementary refuse burning, needs some assurance of guaranteed supply, particularly in view of the prolonged sanitation men's strikes that have occurred in several large cities in the recent years. One solution may be a State agency guaranteeing the refuse supply and providing cash payments or covering the haul cost from a more distant location in the event of a major disruption of refuse supply. Scheduling also poses problems as refuse is normally collected only five days/week whereas power generation is uoully a continuous sevenday/week operation. Storage facilities to cover weekend periods could be provided, or refuse could be burned only on weekdays (but the latter incurs a penalty due to underutilization of the modifications to the boilers and feeding equipment). On the other hand, in a number of large cities the electricity (or steam) demand is considerably lower on weekends than on weekdays.

Most of the resource recovery options require some prior processing of the refuse, at least shredding and removal of magnetic materials. The question is who should build, own, and operate the facilities for this. In the case of direct burning of refuse in utility boilers, the consensus is that it should be the municipality which could then offer the utility a fuel roady for burning.

Recenl developments suggest that the most promising approach may involve a private-sector middleman. For example, Jersey Central Power and Light (JCP\&L) recently announced an agreement with Energy systems, a division of Wheelabrator-Frye that loulas the U.S. ri.ght.e to the Swiss developed Von Roll incinerator design. 4 Under the 25-year agreement, Energy systems will desigro, build, own, and operate the refuse-to-energy facility; and JCP\&L will build a nearby substation and guarantees to purchase the power at a "price competitive with the utility's alternative generating sources." The 
-5 million facility will have a design capacity of $110 \mathrm{MW}$, with initial daily refuse capacity of 2000 tons/day rising to 4000 tons/day. Energy systems will make agreements with local municipalities to obtain the necessary refuse.

Private industry is attracted to such a brokerage position between utility and municipality for a number of reasons, but mainly because under existing and expected energy prices the anticipated rate of return on the energy-recovery conversion is sufficient to attract the necessary capital. Many utilities prefer to deal with such private sector operators, with whom they can enter into long-term contracts as with other fuel or bulk power suppliers, and thus avoid the problems of negotiating with municipalities. Moreover, utilities thus circumvent the need to "get into the refuse business;" since they can simply buy the power from the entrepreneur or, in the case of supplementary refuse firing, buy a fuel ready for burning rather than getting involved with resource recovery operations.

The intent of many statewide solid waste management plans in the Northeast is to obtain private sector involvement in the recovery operations. In Massachusetts, for example, it is hoped that the so-called primary resource recovery centers, whose function is to separate combustible and magnetic fractions from the remainder, would be financed, built, owned, and operated by the private sector, 5 with the state acting only to guarantee delivery of refuse to the recovery center at a certain cost. 6 In fact, the state ran exert significant leverage merely by strict enforcement of current sanitary landfill and air quality regulations. 7 For most urban areas in the Northeast, a disposal cost (whether for landfill or for incineration) lower than that for economic energy recovery can be achieved only at significant environmental penalty. Few incinerators meeting current air quality requirements can be operated at 
less than $\$ 10 /$ ton, a cost that would in most cases make delivery to an energy-recovery facility very attractive. 8

From the municipalities' viewpoint, the entry of private industry into the energy recovery and disposal business offers the significant advantage of relieving them of the burden of capital financing for disposal facilities, which, under existing municipal bond market conditions, is both difficult and expensive. Moreover, many municipalities are long accustomed to dealing with private industry in the collection of solid waste, and thus extension to disposal and resource recovery appeara quite logical.

The ability of municipal electric utilities to internalize the entire operation remains somewhat questionable. Many of these are relatively small, inefficient producers of electric power, operating old generating plants far too small to exploit the scale economies available at unit sizes nf $600 \mathrm{MW}$ and beyond. 10 Few small Ilunicıpal utilities are likely to find modification of their boilers to burn refuse an economic proposition (although there are significant exceptions). 11 Nevertheless, from an iatitutional viewpoint, cities with their own generating plants appear to be in a good position to exploit the solid waste resource, and the question warrants further study.

The situation is similar for steam generation from refuse, whether for inc̈ustrial use or district heating. Indeed, the Saugus facility, providing steam to the General Electric plant in Iynn, was originally planned as a GE owned operation, ${ }^{12}$ but difficulties in reaching an operating agreement and organizing a reglonal solid waste district to supply the refuse led to construction of the plant by the Refuse Energy systems Company (a joint venture of the D. Mattio Construction Company and Wheelabrator-Frye).$^{13}$

A number of analyses point out that the cost of capital is much higher to private than. to municipal borrowers because of the tax exemption on municipal bond interests, ${ }^{14}$ which may increase 
he costs by as much as a $\$ 2.00$ to $\$ 3.00 /$ ton. 15 Note, however, that public ownership does not lower the opportunity cost of capital to the economy as a whole because the lower costs to the government owning the facility are offset. by higher costs to others in the economy resulting from the subsidies that allow the municipal bond rate to be below the opportunity cost of capital. Moreover, recent increases in interest rates on municipal borrowing, which some observers feel may persist for some time, make this advantage less compelling. 16

In assessing the importance and possible means of redressing institutional problems, the experience of New York, especially New York City, is illuminating. As noted by Low, 17 existing legislation to protect the consumer may offset even a strong economic advantage offered by the use of refuse-derived fuels. Since New York utilities must pass any savings due to fuel economy on to their consumers (since additional fuel. costs are also passed on directly). a utility has no direct profit incentive to accept refuse fuels. However, since fossil fuels have as much as tripled in cost over the past few years, ${ }^{18}$ some utilities (in New York, especially Consolidated Edison) have been faced with severe customer resistance to price increases, which makes the use of cheaper fuels more attractive to them. Indeed, plans are now moving forward to burn 1000 tons/day of refuse at Consolidated Edison's oil-fired Arthur kill plant on staten Island. 19

In an analysis of the statewide problems in New York, Axelrud 20 noted that, despite the optimism of many municipalities regarding the feasibility and economics of energy recovery, utilities were rejicting the use of solid waste as fuel because of two fears: that the municipalities would not commit themselves-.to long-term agreements necessary for recovery of capital expenses, and that they might be tempted to use the utilities as a revenue source by 
future increases in the solid waste price. To allay these fears, the New York Public Service Commision issued a statement of policy on burning municipal wastes in February 1974 which called for the electric utilities to cooperate with the municipalities in disposing solid wastes but recognized the responsibility of the electric utilities to maintain high quality service at a reasonable cost and the responsibility of the public authorities for disposal of general municipal wastes. The Commission limited the utilities' financial participation to expenditures for modifications of or additions to boiler equipment and the purchase cost of processed solid waste fuel, and it restricted the utilities from expending funds on solid waste processing facilities or financing facilities for collection and processing. These activities are limited to the community, which is financially supported by the Environmental Bond Act. Overall, the Commission defined the utilities' financial participation as not exceeding the costs of alternative boiler fuel. systems. As noted by Axelrod, this policy appears restrictive but, in effect, it set clear guidelines for utility participation and eliminated the fear of the utilities that they might end up footing the entire bill in the name of community relations. 21

The response has been positive: during 1974 each of the electric utilities in the state met with many local communities to discuss cooperative programs. As a result, four utilities agreed to assist communities with four separate engineering and economic studies to determine the feasibility of a solid waste reclamation center in conjunction with a steam eloctrie plant. To date three ot the four studies are complete, and two utilities, Long Island Lighting Company and Rochester Gas and Elertsic, have formally agreed Lu purchase a solid waste fuel from the communities.

One can thus conclude that, whatever the apparent difficulties presented by prevailing institutional conditiuns, sufficient resolve 
in the part of a municipality or the state to opt for solid waste sesource recovery is readily translated into the political measures necessary to surmount them. In view of the recent continuing rise in energy prices, which makes it possible for private industry to set an adequate rate of return on investment in resource recovery facilities and makes utilities anxious to find substitutes for increasingly expensive fossil fuels, institutional problems should not prove to be insurmountable in implementing energy recovery from solid waste. 
NOTES TO CHAPTER VI

1. "Local Trash Cuts Downtown Fuel Bills", Environmental Science and Technology, September 1972 , p. 780 .

2. See e.g., "Connecticut's Energy Outlook: 1975-1995", Connecticut Energy Àdvisory Board, January 1975.

3. For a good review of the financial and contractual problems from'the utility perspective see e.g. Bechtel corporation. "Fuels from Municipal Refuse for Utilities - Technology Assessment" Report to the Electric Power Research Institute, Maral 1975 (NTIS PB 242 413).

4. As reported in Electrical World, June 15, 1975.

5. A. D. Little Inc., "A Systems Evaluation of Alternative Statewide Resource Recovery Options for the Disposal of Municipal Solid Waste" Report to the Massachusetts Department of Publin Works, December 1973.

6. And, if necessary, provide residual landfill sites during the transition peroid before operation of the two secondary facilities for recovery of non-ferrous glass from the residual fraction produced at the primary facility.

7. Passage of a Tennessee law requirlng all sanitary landfills to use ddily earth cover provided the impetus for organizatinn of the Nashville district heating scheme. (Not only does the law raise the cost, but also the site capdelty is sharply renuced by the carth cover).

8. A recent analysis for Connecticut estimated the cost of new incinerator capacity as $\$ 17$ to $\$ 25 /$ ton. (see note 2 , supra, p. D-124).

9. Some municipalities, too, would prefer "to stay out of the energy huoiness." The Commissioner of Streets and Sanitation of Chicago, at a conference at which he outlined plans for burning refuse at a Commonwealth Edionn coal plant, noted, in response to a question as to why the city did not itself burn its refuse and sell the utility steam, "... we did not want to get into actual energy production." (A.I.Ch.E. Workshop on industrial Process Design For Pollution Control", Vol. 6, Chicago, Ill, Octuber 1973, p. 106). 
. For a discussion of this point, see e.g., R. L. Wallace and P. E. Junk, "Economic Inefficiency of Small Municiapal Generating Systems", Land Economics, XIVI, 1, p. 98 (February 1970).

11. One example frequently cited is Ames, Iowa, which operates its own municipal electric generating plant, a 33-MW coal/gas-fired unit plus a 20-MW oil-fired gas turbine. Refuse will be burned in one of the three steam boilers at 10 to $20 \%$. Since the generating plant runs directly under the supervision of the mayor and council, through the city manager, cooperation within a single city administration was relatively easy to achieve. For further details on the Ames project, see A. O. Chantland. Making Kilowatts out of Refuse" The American City, September 1974.

12. Metcalf \& Eddy, Inc., "Generation of Steam from Solid Wastes", U:S. Environmental Protection Agency, 1972 (Published by NTIS PB 214 166).

13. "Refuse to Energy Plant Uses first Von Roll Incinerators in the U.S.", Environmental Science \& Technology, Vol. 8, No. 8, p. 693, (August 1974).

14. See e.g., J. G. Abert, H. Alter, and J. F. Bernheisel, "The Economics of Resource Recovery from Municipal Solid Waste", Science 183, 1052-1058 (1974) or H. W. Schulz, "Cost/Benefits of Solid Waste Reuse, "Environmental Science \& Technology, Vol. 9, No. 5, p. 423, (May 1975).

15. Midwest Research Institute, "Resource Recovery - The State of Technology Report to the Council on Environmental Quality," February 1973.

16. Unfortunately, there is some doubt as to whether the pollution control bond, a variant of the tax-free industrial development bond, might be a suitable way of financing the capital costs. These bonds are issued by local governments to buy or build capital facilities, which are then leased to private corpora.tions. Although the 1968 Industrial Revenue Bond Act stipulated that no individual offering could be larger than $\$ 5$ million, the financing of pollution control equipment was specifically exempted from this requirement. Electric utilities were early beneficiaries of this provisinn. In April 1974, the Internal Revenue Service approved such bonds for the fllldiling of solid waste recycling facilities, but wjth restrictions; to qualify, the processed material must be of no value to the pruduccr and cannot be used or sold by the producer at the location of processing. (see Albert et. al. note 14 , supra). 
17. R. A. Low "Energy Conversion in New York" Proceedings, First International Conference on Conversion of refuse to energy, Mintreux, Switzerland, November 1975, p. 250.

18. The cost of No. 6 fuel oil with $0.3 \%$ sulfur used by consolidated Edison has tripled since 1973.

19. Originally the city assumed the cost of the feasibility studies. But in recognition of the contribution the refuse-derived energy would make to the Project Independence strategy, a $\$ 5,000$ Fereral grant was also made, since almost all of Consolidated Edison's oil is from foreign sources. It is estimated that the refuse used at Arthur Kill would replace about 1400 harrcls of imported oil per day. See Low, note 17 , supra.

20. H. J. Axelrod "Utilization of solid waste in New York: A State Government's Positive Action Program". Proceedings, First International Conversion of Refude tu Energy, Montreux, Switzerland, Novemuer 1975, p. 447

21. Ibid, p. 480 .

22. Rochester Gas and Electric will purchase a briquette derived from solid waste to burn in a coal-fired plant, and Long Island Lighting has agreed to purchase a 32-MW turbine generator to be installed at the Town of Hempstead's resource recovery site, where the Town will produce steam from burning solid waste. The Hempstead facility will be in service by mid-1977. 
CHAPTER VII

SECONDARY IMPACTS

\subsection{Environmental Ramifications}

The conversion of the organic fraction of refuse into energy has a number of potential impacts on the environment, ranging from direct affects on air quality due to pollutant emissions to indirect effects on. land use; on balance, the net environmental impact is clearly positive.

Regardless of which conversion option is chosen, if the alternative refuse disposal method is landfilling, the major environmental impacts are the substantial reduction of land required for disposal and the elimination of concomitant secondary effects such as water pollution from landfill leachates. ${ }^{1}$ since incinerators achieve average volume reductions of $95 \%$, disposal of the residue should use only $5 \%$ of the area needed for raw refuse landfill and in fact uses less because the residue is inert and does not require daily earth cover; hence a given fill area lasts longer. Since the energy recovery options discussed in this report all produce the same volume and weight reduction as does incineration, they provide a substantial saving in land area.

The impact of direct refuse firing on pollution emissions and air quality is difficult to assess. Refuse typically has a sulfur content of some $0.1 \%$, substantially below that of even socalled low-sulfur coals. Sulfur limitations in fuel in tle Northeast vary widely, from a low of $0.2 \%$ by weight to a high of $2.5 \%$ in parts of Maine and Pennsylvania. ${ }^{3}$ The $0.1 \%$ sulfur content of refusc should be adjusted for the lower Btu content: the sulfur content of refuse can be expressed as $0.221 \mathrm{~b} / 10^{6} \mathrm{Btu}$; whereas a $1 \%$ sulfur coal of $12,020 \mathrm{Btu} / \mathrm{Ib}$ has a eulfur content of $0.831 \mathrm{~b} / 10^{6}$ Btu. Hence a power plant burning $1 \%$ sulfur coal, if it used refuse 
to supply $20 \%$ of its heat input, whould decrease its sulfur emissior by $15 \%$, from 0.83 to $0.71 \mathrm{lb} / 10^{6} \mathrm{Btu}$.

Burning refuse at a firing rate of 10 to $30 \%$ in a plant using high-sulfur coal would not eliminate the need for a flue gas desulfurization (FGD) system. Even if refuse had zero sulfur content, the maximum possible reduction in $\mathrm{so}_{\mathrm{x}}$ emissions would be * equal to the firing rate, which probably will not exceed $30 \%$. Burning high-sulfur coal, however, requires so removal efficiencies of $80 \%$ and higher, significantly above the 15 to $30 \%$ reduction due to burning partly refuse. Conversely, however, with an FGD syetem of given effirionoy, Lle sulfur cuntent of the coal could be raised by the corresponding percentage without affecting $\mathrm{SO}_{\mathrm{x}}$ emissions. For example; a plant burning $3 \%$ sulfur coal, with a FGD system of $80 \%$ efficiency, could, if burning $20 \%$ refuse, use $3.75 \%$ sulfur coal with no increase in so ${ }_{x}$ levels. The ability to burn higher-sulfur coal is a further economic advantage, not considered in section $V$, since the price of coal is significantly affected by its sulfur content.

How do these expectations match reality? Unfortunately, the few tests conducted in St. Louis show little evidence of significant decreases in gaseous pollution levels, and a statislically significant decrease in so ${ }_{\mathbf{x}}$ emission lerolo has yet to be established. 4 It is unlikely, however, that so $_{x}$ emissions would increase.

Another major air pollutant is particulate emission. Since refuse has a higher ash content than coal, higher particulate loadings at the inlet to electrostatic precipitators, as observed at the st. Louis project, are not expected. Even though the predipitator efficiency decreased when refuse was fired $b$ so that particulate unissiun levels increased), it was assumed that this could be corrected by adjustment and optimization of precipitator operation. 
The loss of efficiency was thought to be due to the higher moisture content of the emissions affecting the performance of the precipitators. 5

The direct firing of refuse in coal-fired boilers has some interesting secondary impacts on human health. Sanitationmen who collect refuse have one of the highest occupational injury rates (higher than coal miners or construction workers ${ }^{6}$ ), but collection work is largely unaffected by the disposal option. However, the partial replacement of coal by refuse results in a proportional reduction in occupational injuries in coal mining; also, $x \%$ substitution of refuse for coal results in $\mathrm{x} \%$ reduction in the environmental impacts associated with coal mining, processing, and transport for power generation. Hamilton and Morris ${ }^{7}$ have estimated that supplying the coal to support a 1000-MW power plant results in 0.6 accidental deaths and 30 disabling injuries (with a mean time loss of 50 days) per year of operation. Since coal-fired power generation in the Northeast now amounts to some $28,000 \mathrm{MW}, 8$ the benefit to occupational health from substituting. refuse at an $18 \%$ firing rate would be avoidance of 3.02 deaths and 7560 man-days of disablement per year.

Both pyrolysis and waterwall incineration would have the same air pollution impacts as conventional incineration because the emission standards would be the same. Landfill disposal of the residues would also be the same, as in the conventional case.

A major advantage of bioconversion is the simultaneuus handling of municipal sweage sludge, (see section 3.2.) the addition of which is almost mandatory because it is the cheapest source of phosphorous and nitrogen nutrients essential to successful microbial conversion. The disposal of sewage sludge is one of the thorniost issues in municipal waste treatment, with total processing and disposal costs currently in the range of $\$ 30$ to 50 per ton of dry solids. Since 
the generation rate of sewage sludge solids is about $0.1 \mathrm{lb} / \mathrm{cap} / \mathrm{day}$ a 1000-tpd refuse-to-energy facility, serving some 571,000 persons, would simultaneously dispose of the 28.5 tons of sludge solids generated by the same population. The conversion facility would thus be credited $\$ 1.14$ per ton of sludge solids ( $\$ 416,000$ per year). The environmental benefit is elimination of the need for sewage sludge landfill or incineration.

\subsection{Relationship to Materials Recovery Options}

The recovery of materials from the noncombustible fraction of refuse is largely unaffected by the recovery of energy from the combustible fraction. Indeed, to the extent that the separation of metals and glass before burning or cnnversiun is desirable, it would he otiniulated by energy costs recovery because its costs would be shared.

The use of refuse for energy precludes recovery of materials from the combustible fraction, particularly paper fiber. Present and anticipated market conditions for paper fiber recycling, make fiber recovery uneconomic except in special circumstances. 9 In contrast to the consistent upward trcind in energy prices, the markel for recyclable paper products exhibits wide and rapid fluctuations. In 1972-1973, for example, used cardboard sold for $\$ 70 /$ ton and newsprint for noarly $\$ 30 /$ ton, but by mid-1975 the tormer brought little over $\$ 20 /$ ton and the latter only $\$ 10 /$ ton-if a market could be found. 10 such swings discourage private industry, which seeks stable and assured returns on capital. None of the statewide solid waste manageluent plans in the Northeast envisages the recovery of paper fiber from mixed municipal refuse, and all consider the optimum use of the cumbustible fraction to we eliergy recovery. Since most of these plans were completed before the post-embargo increases in energy prices, their conclusions remain sound. 11 . 
A small market for recyclable waste paper dies exist in the .ortheast, estimated at no more than $15 \%$ of the total wastpaper content of municipal refuse. In Massachusetts in 1975 the estimated market for recyclable wastepaper was 566,000 tons, while in municipal refuse the total wastepaper was 3,375,000 tons and the total combustible material 4,693,000 tons $^{12}$ so that even satisfying the entire market for recyclable newsprint by source separation would have diverted only $12 \%$ of the combustible waste stream.

The breakeven price of refuse as a coal substitute is in the range $\$ 3$ to $8 /$ ton (see Figure 12 , Section 5.2). Sincie paper contributes some $75 \%$ of the total Btu but constitutes only some $40 \%$ of the weight, wastepaper has a fuel value of $\$ 5.60$ to $15 /$ ton and must fetch at least this price in the recycling market for that use to be competitive; this may have happened in 1972-1973 but seldom does under normal market conditions. The wastepaper market can probably be adequately served by continuing current source separation methods. such as Boy scout paper drives ald local recycling centers typical of middle-class suburbs, which do not significantly affect energy recovery from refuse. 
1. The problem of landfill leachates has recently become prominent because of efforts to eliminate sources of water pollution. Direct groundwater contamination can be avoided by lining the landfill and treating the leachate, but such measures are very expensive.

2. See e.g., R. A. Colonna and C. McLaren, "Decision-makers Guide in Solid Waste Management", U.S. Environment́al Protection Agency, Report SW-127, 1974 .

3. See B. S. Edelston and E. S. Rubin, "Current and Future Use of Coal in the Northeast," BNL 50560 (May 1976), Environmental Studies Instilute, Carnegie-Mellon University., Fil.tshurgh, Pennsylvania.

4. L. J. Shannon, et al, "St. Louis/Union Electric Refuse Firing Demonstration Air Pollution Test Report", U.S. Environmental Protection Agency, August 1974, (Published by NTIS PB 237 630).

5. Ibid, p. 74 .

6. In 1970, there were 63.9 injuries and 2598 days of disability per million man-hours worked in sanitation; the corresponding figures for coal mining were 41.6 and 7793 and for the construction industry, 28.0 and 2100. (see P.M. Meier) Kuhner, and R. E. Bolton, "Wet Systems for Residential Refuse Collection: A Case Study for Springfield, Mass.", U.S, Environ. mental Protection Agency, March 1974 (Published by NTIS PB $234.96)$.

7. L. D. Hamilton and 5. C. Morris, "Health Effects of Fossil Fuel Power Plants", Proceedings, 8th Midyear Topical Symposium of the Health Physics Society, Knoxville, Tenn., October 1974 (Published by NTIS CONF 741 018), p. 305-316.

8. Baded on S. Rahman, "Issue Paper on the Electrical Sector, 19502000", BNL Regional Energy Studies Program, Draft Report, September.1975, Tables 19 and 20.

9. The rorovery plant in Franklin, Ohio, noted in Chapter I, is such an exception, but here the recovery fiber is delivered to an adjacent roofing felt mill.

10. Environmenta 1. Soience and Technology, Vol. 9, No. 12, p. 1015, November 1975. 
The essential features of these plans are outlined in the latter pages of Appendix F.

12. A. D.. Little, "A Systems Evaluation of Alternative Statewide Resource Recovery Techniques for the Disposal of Municipal Solid Waste, "Massachusetts Department of Public Works, December 1973 , p. 12 . 
THIS PAGE

\section{WAS INTENTIONALLY \\ LEFT BLANK}




\section{SENSITIVITY ANALYSIS}

\subsection{Sensitivity to Per Capita Refuse Generation Rates}

In Chapter II, we discussed a number of different predictions of per capita refuse generation rates: a low case, in which we assumed no change in current per capita generation rates: a median case, in which we assumed that arrent generation rates would increase by $1.5 \%$ per year in accordance with trends in comsumption of non-durable goods; ${ }^{1}$ and a high case based on extrapolation of the regression equation, used to characterize 1975 rates into the future. In subsequent computations the median generation level has been used as the base case, and here we review the sensitivity of energy yield to this assumption.

Using the computer model, one can readily compute the quantity of refuse economically deliverable to a central conversion facility in each SMSA, assuming for purposes of comparison that all such refuse would be used as a boiler fuel to generate electricity. From another Issue Paper in this study, one can obtain a range of electric energy demands in the Northeast, ${ }^{2}$ and thus a useful analysis is to examine the percentage of electric demand that could be supplied by refuse under different combinations of per capita refuse generation and total electric demand.

The results of such an analysis for 1985 and 2000 are displayed on Tables 13 and 14 , respectively. These show that even under the most favorable circumstances (low electricity demand, high refuse generation), at most $13 \%$ of the demand could be satisfied; but since, as noted elsewhere, not all SMSA's have sufficient coal fired generating capacity to use the retuse, the actual percentage contribution is likely to be much lower. Conversely, under the most unfavorable circumstances (low refuse generation, 
$\underline{\text { Table } 13}$

PERCENTAGE OF 1985 RZGIONAL ELECTRIC DEMAND POTENTILLLY CONTRIBUTED BY REFUSE

1985 Electricity Demand ${ }^{a}$

\begin{tabular}{|c|c|c|}
\hline$\left(480 \times 10^{\text {Low }_{6}} \mathrm{Mwh}\right)$ & $\begin{array}{l}\text { Median } \\
\left(555 \times 13^{6} \text { Mwh) }\right.\end{array}$ & $a_{6}$ \\
\hline
\end{tabular}

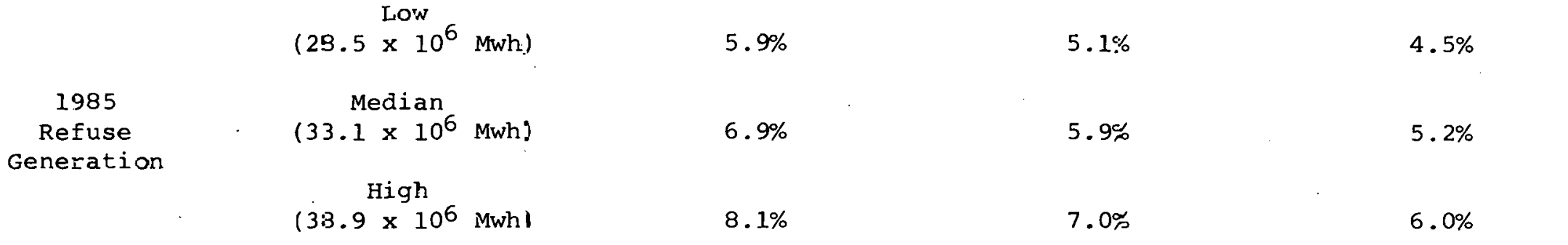

aSource: Meier, et $a_{-}^{-}$, Note 2, Chapter III.

Table 14

PERIENTAGE OF 2000 REGIONAL ELECTRIC DEMAND POTENTIALLY CONTRIEUTED BY REFUSE

2000 Electricity Demand ${ }^{a}$

\begin{tabular}{lcc} 
Low & Median & High \\
$\left(681 \times 10^{6} \mathrm{Mwh}\right)$ & $\left(1900 \times 10^{5} \mathrm{Mwh}\right)$ & $\left(1158 \times 10^{6} \mathrm{Mwh}\right)$ \\
\hline
\end{tabular}

$\begin{array}{cccc}\text { Low } & & \\ \left(36.0 \times 10^{6} \text { Mwh }\right) & 5.2 \% & 4.0 \% & \\ \text { Median } & & & 4.5 \% \\ \left(52.0 \times 10^{6} \mathrm{Mwh}\right) & 7.6 \% & 5.7 \% & \\ \text { High } & & 10.1 \% & 7.8 \% \\ \left(90.7 \times 10^{6} \mathrm{Mwh}\right) & 13.3 \% & & \end{array}$

urce: Meier et al, Note 2, Chapter III. 
igh electricity demand), only some $3 \%$ could be contributed by refuse. The overall contribution, then, is likely to be around $6 \%$, with the uncertainty in per capita refuse generation assumption resulting in a deviation of a few percent in either direction. 8.2 Sensitivity to Population Density Gradient Assumptions

In Chapter $V$ we noted that haul costs were a function of population density, postulated as declining exponentially from the city center. Thus, the equations for cost and refuse quantity derived in that Chapter incorporated the density gradient $\alpha$ and central density $d_{0}$ (see e.g. Eq. [7] or[9]), the parameters of the model describing the exponential density relationship as ${ }^{3}$

$$
d(r)=d_{0} e^{-\alpha r}
$$

where $d(r)$ is the population density at distance $r$ from the center.

In making projections for the future cost and refuse quantity functions, which determine how much refuse is economically delivered to an energy conversion facility, one must go beyond total future population (which, for each SMSA, is given for purposes of the BNL futures study as the OBERS Series E projection), but consider also the future values of central density and density gradient. . Indeed, by integrating Eq. [10], one obtains 4

$$
P(R)=\frac{\theta \alpha}{\alpha^{2}}\left[1-(1+\alpha R) e^{-\mu R}\right]
$$

wliere $P(P$.$) is the total population within a radius R$ and $\theta$ is the sector angle. ${ }^{5}$ Thus, as $P(R)$, the SMSA population, chauges through time, $\alpha$ and $d_{0}$ must change also. As American cities have grown over the past few decades, a decrease in density gradient has occurred, aracteristic of urban sprawl. 
For the base case computations, it is assumed that SMSAs in the region will continue current trends of urban sprawl over the next 25 years. Thus, the decline in density gradient from 1960 to 1970 has been extrapolated linearly, with future values of $\alpha$ as shown in Table 15. Using these values with the corresponding OBERS projection for $P(R)$, one can determine a value of $d_{0}(t)$ from Eq. [11]. The do values obtained this way are also shown in Table 15; and, as expected, $d_{0}$ values also decrease with continued urban sprawl. 6

Alternatively, assume a scenario characterized by revitalization of the city center with dentral densities remaining at 1970 levels. Inserting constant $d_{0}$ and increasing population into Eq. [10] again results in changing values of $\alpha$ with time, although, as evidcnt Irsm table 16, the dermsaso in denstey gradient is much less than in the urban sprawl case. An iterative method must be used, however, because with given values for $P(R)$ and $d_{0}$, one cannot solve $E q$. [11] for $d_{0}$

Comparing the results of the revitalization case with those for the base case shows the former to yield $15 \%$ greater Btu yield ecoriomically recoverable by the year 20nn. However, many of the smaller SMSAs show little or no increase ${ }^{7}$ with this scenario, whereas the larger SMSAs show a much higher increase. 8 The redson is that in the smaller SMSAs, all or moot of the refuse would be economically hauled to the central facility, even in the base case, whereas in the larger ones, the optimal rolleation radius does not encompass the entire population and hence concentration of the population results in a greater proportion of the toeal refuse being economically recoverable.

\subsection{Sensitivity to_Refuse Composition Assumptions}

In order to establish an upper limit for subsequent scenario development, the sensitivity of energy. conversion to refuse composition was evaluted in conjunction with the urban revitalization 
Table 15

URAAN GRONTH SCENARIO 1 - CONTINUED UR QAN SPRAKL

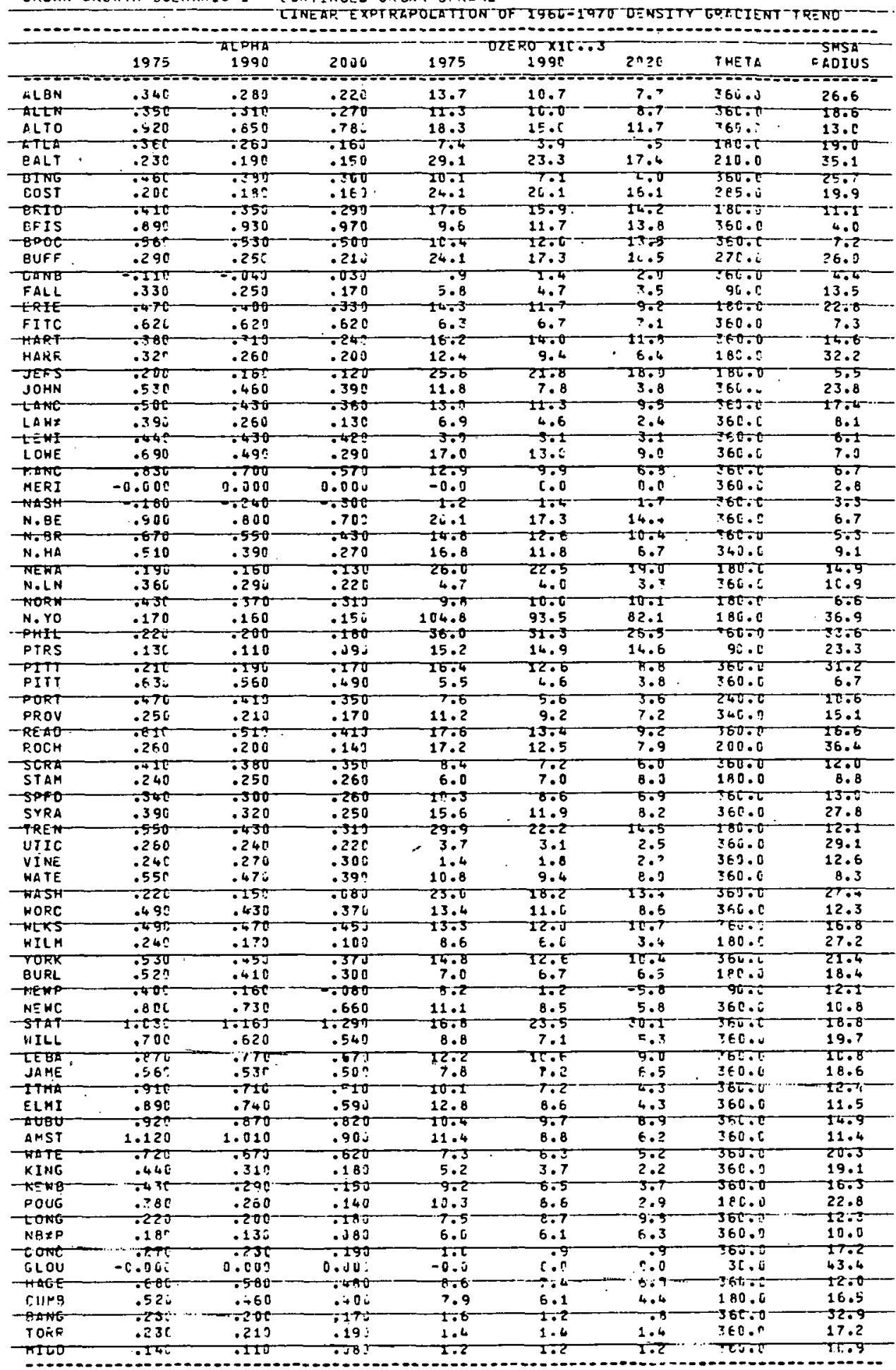

* Full names of cities appear in Table 3. 
Table 16

LREAA GRCWPH SCENARIO 2 - LIMITEE SSPATIAL GROWYH

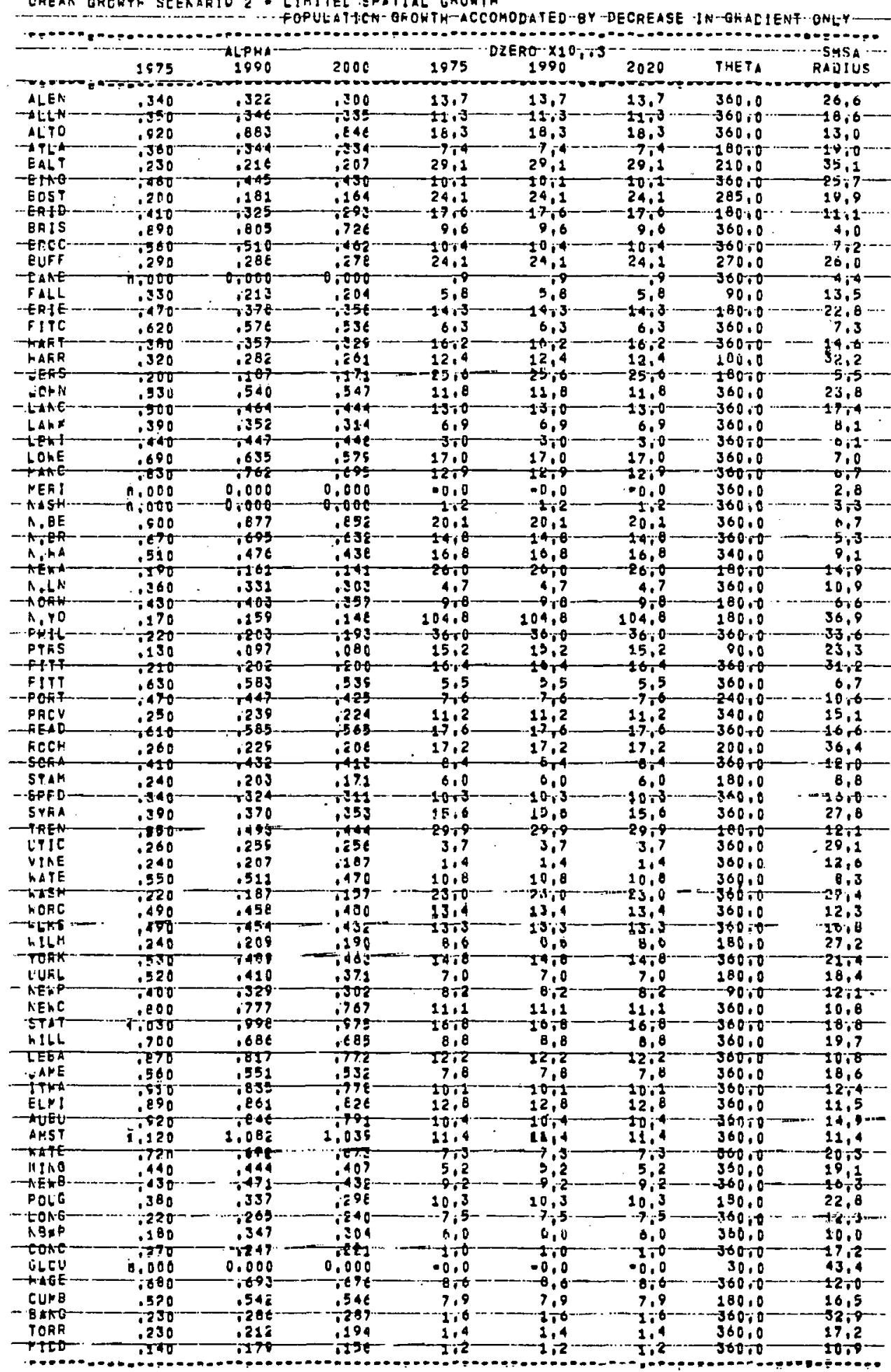

* Full names of cities appear in Table 3. 
lario for population density distribution. Besides the base case refuse composition (Table 4 , Section II), for which a modest increase in comlustiblc materials was assumed, two others were considered; one remaining unchanged at the current $\mathrm{mix}$ and one containing a much higher fraction of combustibles (especially paper and plastic) because of assumed widespread use of home garbage grinders and returnable beverage containers (see Table 17).

Results of computer analysis show remarkably little sensitivity to composition; as indicated by Figure 17, which shows the potential yield in $10^{12}$. Btu coal equivalent economically delivered to energy conversion facilities. Most of the rise in energy yield by 2000 is seen to be due to increases in population and in per capita refuse generation (a rise of $300 \%$, from 287 to $1020 \times 10^{12}$ Btu/yr). For the lowest case examined, i.e., base case composition and low per capita generation (no increase over present levels), the yield increases only to $460 \times 10^{12} \mathrm{Btu} / \mathrm{yr}$. Clearly, the assumption that introduces the greatest degree of uncertainty'is that for per capita generation rates.

Table 17

REFUSE COMPOSITION (\% OF WET WEIGHT) FOR THREE CASES : BASE CASE, CONSTANT COMPOSITION, AND HIGH CUMBUSTIBLES

\begin{tabular}{|c|c|c|c|c|c|c|c|}
\hline & & & 1985 & & & 2000 & \\
\hline & Current & Base & Const. & High & Base & Const. & High \\
\hline Paper & 40.0 & 44.9 & 40.0 & 47.5 & 49.7 & 40.0 & 55,0 \\
\hline Garbage & 20.5 & 16.3 & 20.5 & 12.8 & 12.1 & 20.5 & 5.0 \\
\hline Garden waste & 13.5 & 12.7 & 13.5 & 11.8 & 11.8 & 13.5 & 10.0 \\
\hline Plastic & 1.5 & 2.9 & 1.5 & 5.8 & 4.2 & 1.5 & 10.0 \\
\hline Metal & 8.9 & 8.2 & 8.9 & 7.8 & 7.4 & 8.9 & 6.7 \\
\hline Glass & 9.5 & 8.8 & 9.5 & 8.1 & 8.1 & 9.5 & 6.7 \\
\hline Other & 6.1 & 6.4 & 6.1 & 6.4 & 6.7 & 6.1 & 6.7 \\
\hline Total & 100.0 & 100.0 & 100.0 & .100 .0 & 100.0 & 100.0 & 100.0 \\
\hline - .v. Btu/lb & 4500 & 5000 & 4500 & 5663 & 6000 & 4500 & 6937 \\
\hline
\end{tabular}




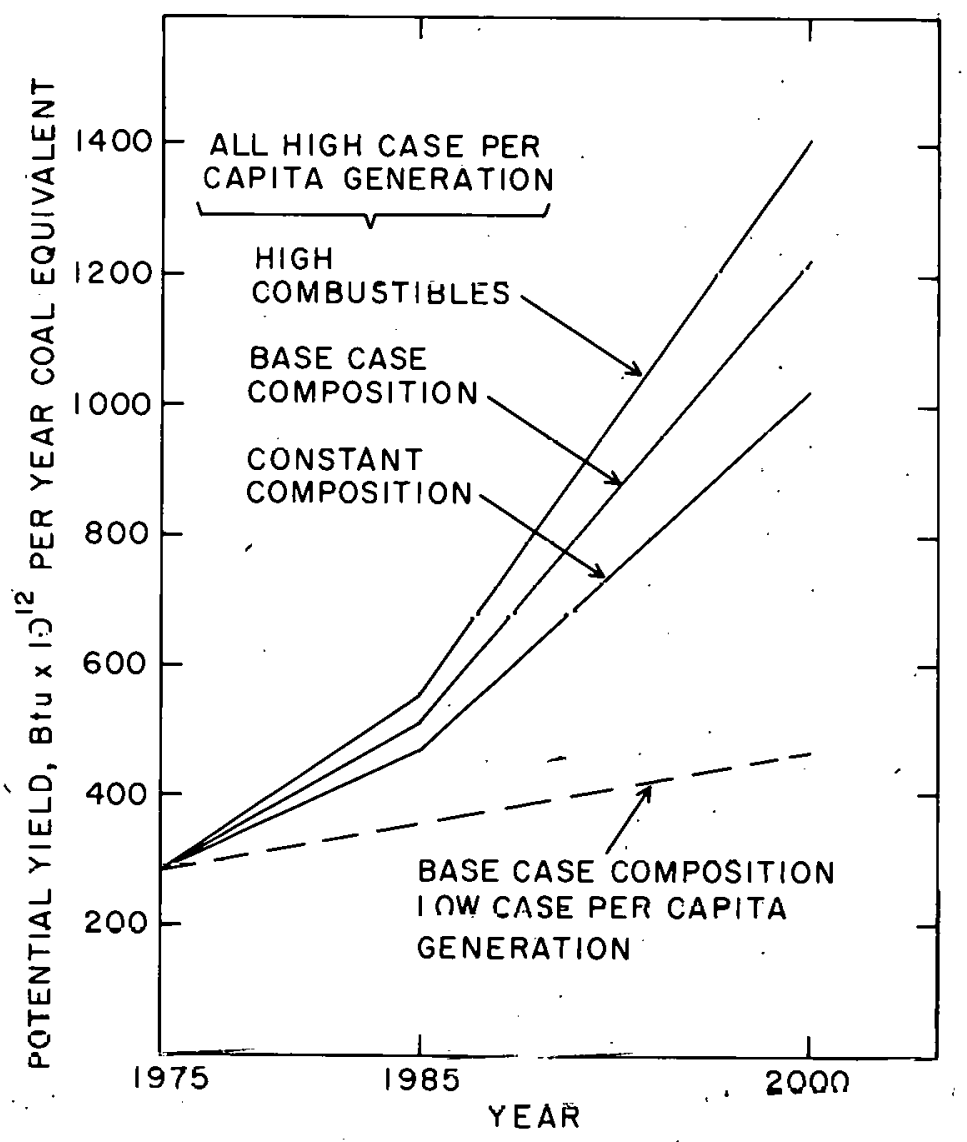

Figure 17. Energy yield as a function of refuse compnsition. 
1. See Section 2.1.

2. P. M. Meier, T. H. McCoy and S. P. Rahman, "Perspectives on the Energy Future of the Northeast: The Electric Sector", BNL - 50553, Brookhaven National Laboratory, Upton, NY, April 1976.

3. This is the classic model of C. Clark, "Urban Population Densities", Journal of the Royal statistical Society, Series A, Vol. 114 , No. 4, p. 490 (1951). For further discussion, particularly in connection with energy planning problems, see P. Meier and T. H. McCoy, "An Analytical Approach to the Determination of Urban Population Density Gradients and Its Application to Energy Planning Problems", BNL - 20196, Brookhaven National Laboratory, Upton, NY, January 1976.

4. Meier and McCoy, Note 3, supra, p. 12.

5. For a circular city, $\theta=360$ degrees or $2 \pi$ radians.

6. Those SMSAs shown on Tables 15 and 16 as having zero $\alpha$ and $d$ in fact have computed values of density gradients that are negative (implying population density increases with distance from the center). These are all small SMSAa, and clearly do not fit our model; in subsequent computations for these SMSAs the program inserts constant population density throughout the SMSA.

7. Reading, Scranton and Waterbury, for example, show increases of $1.78,4.0$, and $0.6 \%$, respectively.

8. New York and Boston, for example, show increases of 29 and $44 \%$, respectively. 
THIS PAGE

WAS INTENTIONALLY

LEFT BLANK 


\section{CHAPTER IX}

SCENARIOS

\subsection{Introduction}

Alternative scenarios can now be posited for energy recovery from refuse. In view of the conclusions of Chapter $v$, the alternatives can probably be limited to direct firing in utility boilers, steam generation for industrial process heat, or gas generation by pyrolysis. Other technologies (such as bioconversion or Garrett pyrolysis) still may be introduced in the Northeast within the time period of interest but are likely to have a limited contribution in comparison with the first three.

The basic assumptions are recapitulated in Table 18. From the OBERS population projections ${ }^{1}$ and the base case estimates for heat value of refuse and per capita refuse generation derived in Sections III and IV, one can readily compute the total quantity of refuse in the region and its energy content since one of the more attractive choices for energy recovery is to burn refuse as a supplementary fuel, an obvious initial step is to correlate projected coal use with refuse availability. Projections for coal use at utility boilers are available from another report, ${ }^{2}$ which gives low, medium, and high projections for coal use (Table 19). Assuming that refuse would be fired at $20 \%$ by heat value, one can derive a potential demand for refuse; as shown in Table 19, this corresponds quite well with the available refuse resource in 1985, independent of the coal scenario. By the year 2000, however, the potential demand ranges from 0.6 of the available resource in the low coal use case to 2.61 of the available resource in the high coal use case. 3

\subsection{Low Case}

In this scenario, it is assumed that by 1985, only projects presently planned will have been implemented, and that in the interval 1985 to 2000 , the rate of implementation will be double 
Table 18

PROJECTIONS FOR THE NORTHEAST

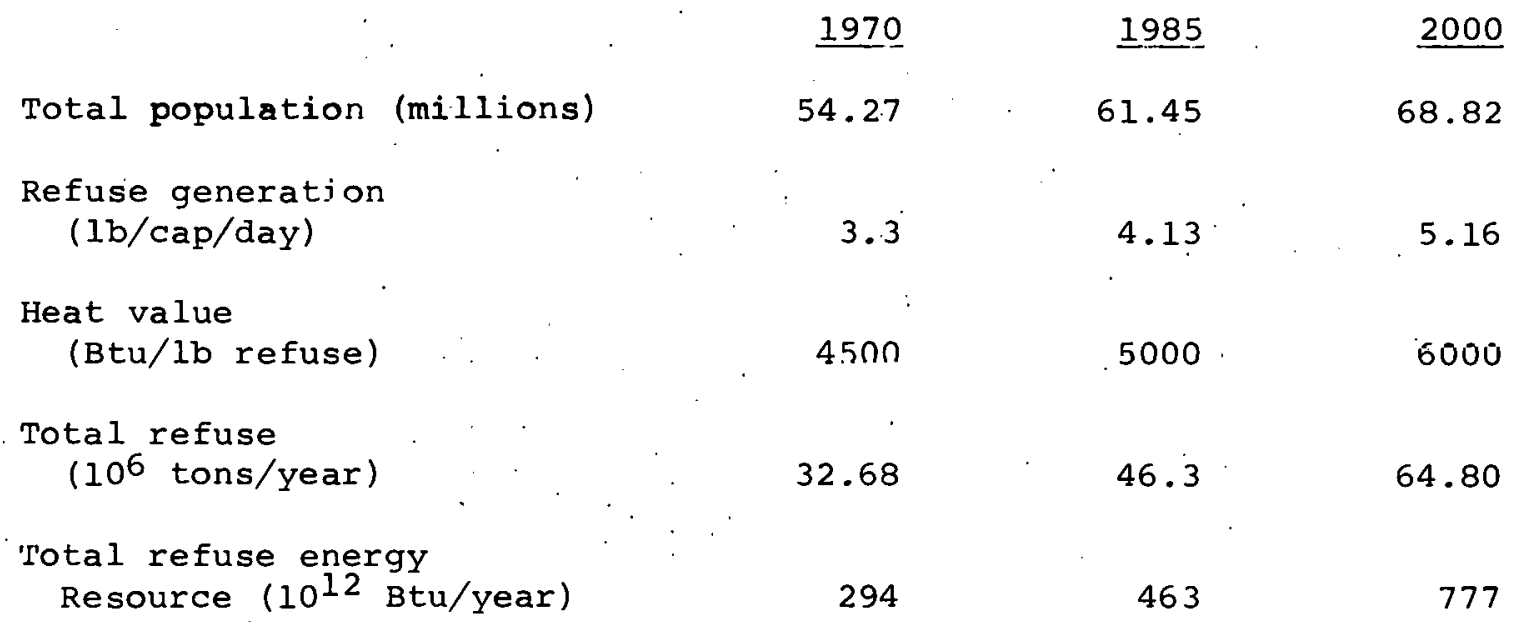

Table 19

REFUSE DEMAND AT COAL-BURNING BOILERS

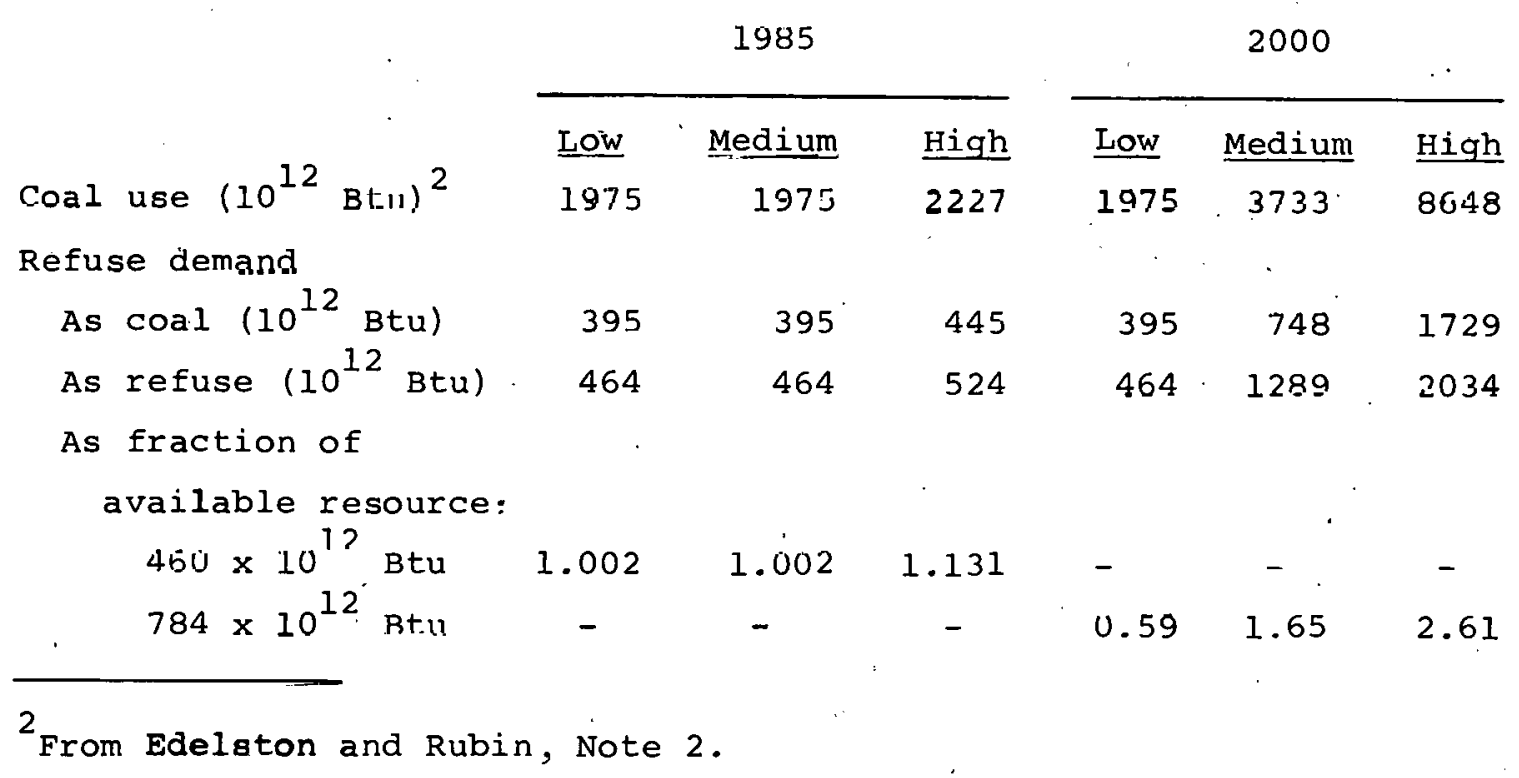


$=$ in the first interval. Currently planned projects are detailed in the Appendix F, and summarized on Table 20. Planned usage totals $56.5 \times 10^{12} \mathrm{Btu} / \mathrm{yr}$, representing some $12 \%$ of the available 1985 refuse resource. By 2000 , with $170 \times 10^{12} \mathrm{Btu} / \mathrm{yr}$ of refuse converted, some $22 \%$ of the resource is utilized. Table 19 also shows that these refuse utilization levels represent only a very small fraction of the potential demand, which implies that only relatively few coal burning plants will have been converted; in the low coal case, the 2000 refuse demand with all facilities converted would be $464 \times 10^{12} \mathrm{Btu}$, as compared with $170 \times 10^{12}$ actually supplied, which implies conversion of only about one third of coal burning plants in the region be converted to supplementary refuse firing.

Figure 18 summarizes the low case scenario. Note that the proportion of refuse going into gas pyrolysis and steam generation is assumed to remain at the current level; if, however, natural gas becomes deregulated, the economics of gas pyrolysis would become more favorable, and this might result in a higher proportion of conversion to gas. 4
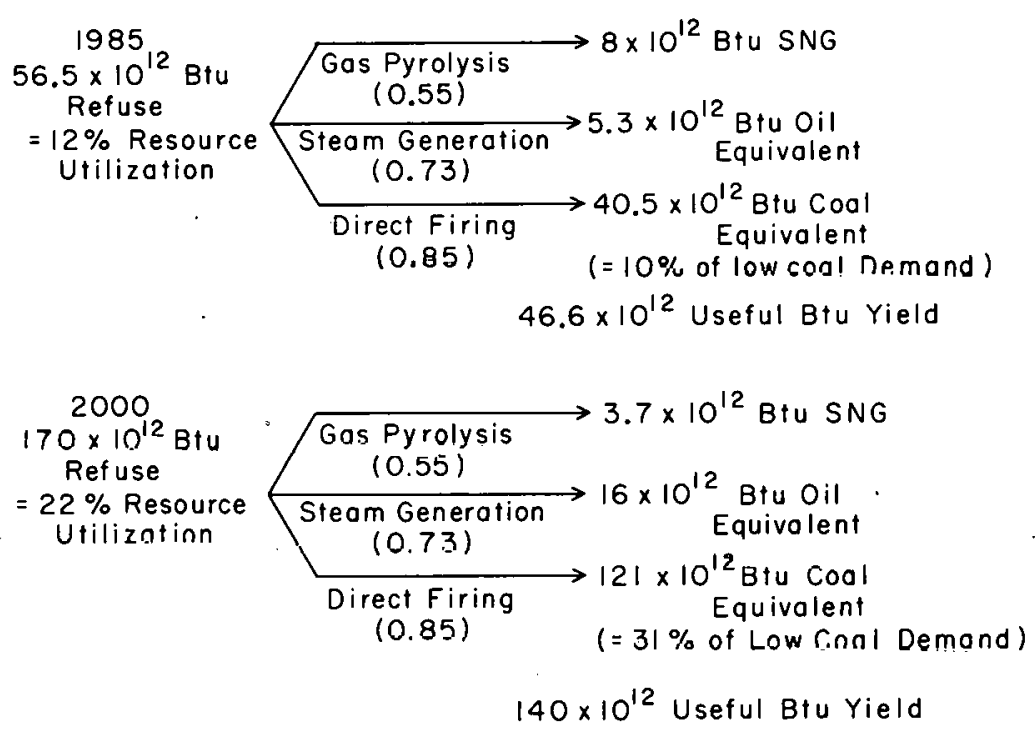

Figure 18. The low case. 
Table 20

1

Type

Direct Firiñg

Steam Generation

Pyrolysis

\section{SLMMARY OF CURRENT ENERGY CONVERSION PRDUECTS}

\section{Location}

Bridgeport

E. Brigewater

Hacker.sack

Hempstead

Housatonic Valley

Roches.ter

Montgonery Cty., MD

N. Britain, CN

New Ỳcrk

Onodaga $c t_{Y}, \mathrm{NY}$

Washington

willimgton

Braintzee, $M A$

Saugus, MA

onondaga Cty., WY

altimore

Mt. Vernon, NY

\section{Tans/day}

1800

600

1000

2000

1500

2000

$-200$

$-800$

1500

1000

1000

500

240

1200

1300

1000

400
Etu/Yx

$5.4 \times 10_{12}^{12}$

$1.8 \times 10_{12}^{12}$

$3 \times 10_{12}^{12}$

$6 \times 10_{12}^{12}$

6. $5 \times 10_{12}^{12}$

6. $\times 10 \times 12$

$5.4 \times 10^{12}$

$4.5 \times 10_{12}^{12}$

$3 \times 10^{12}$

$3 \times 10_{12}^{12}$

$.72 \times 10_{12}^{12}$

$\left.\begin{array}{lll}3.6 & \times 10_{12}^{12} \\ 3 & \times & 10^{12}\end{array}\right\}$

$7.32 \times 10^{12}$

Btu/yr

as Refuse.

$$
\begin{array}{llll}
\Xi & \times & 10_{12}^{12} \\
-2 & \times & 10^{12}
\end{array} \mid
$$

$4.20 \times 10^{12}$ Btu/yr as Refuse. 


\section{High Case}

This case assumes, for every state in the region, complete implementation of statewide solid waste management plans as currently underway for Massachusetts and Connecticut. 5 To be sure, such an assumption depends on political, financial, and environmental policy at the state level, as discussed in Chapter VI; and particularly on strict enforcement of sanitary landfill regulations and air quality standards, which will make incineration without energy recovery less attractive than with it in urban areas, and will preclude open dumps in rural areas. The data in Figure 19 are based on such statewide plans being $50 \%$ complete by 1985 , and $100 \%$ complete by 2000.

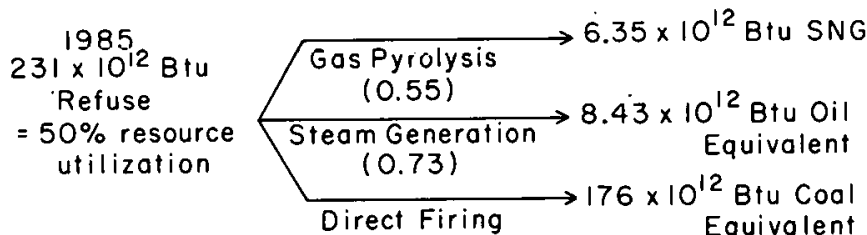

$$
\begin{aligned}
& \text { (0.85) } \quad(=0.37 \text { of potential demand }) \\
& 191 \times 10^{12} \text { useful Btu yield }
\end{aligned}
$$

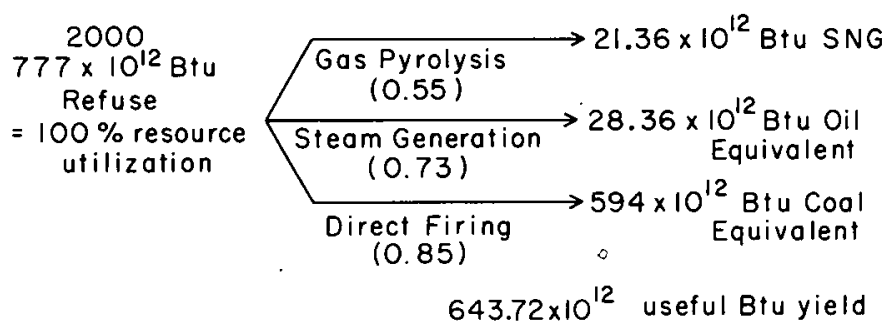

Figure 19. The high case. 


\subsection{Contribution to Regional Energy Supply}

What contribution, then, would energy recovery from refuse make to the future energy supply of the Northeast? Because of the complexity of interlocking alternatives, this question is not easily answered.

The base case 1985 and 2000 resource requirements, as derived in the integrated analysis report of the BNL, Perspectives study ${ }^{6}$ are $20.35 \times 10^{15} \mathrm{Btu} / \mathrm{yr}$, and $31.28 \times 10^{15} \mathrm{Btu} / \mathrm{yr}$, respectively. To these totals, refuse could contribute a maximum of $.231 \times 10^{15}$ Btu in 1985 , or $.7 \% \times 10^{15}$ Btu by 2000 , or $1.1 \%$ and $2.5 \%$, respectively. That, to be sure, is a very small contribution.

But when expressed as a contribution to specific sectors, the result is more encouraging. If all the refuse were converted by pyrolysis to augment natural gas supply, refuse could provide 0.231 $\times 10^{15} \times .55=0.12 \times 10^{1.5}$ Btu of natural gas by 1985 , or $5 \%$ of the $2.36 \times 10^{15}$ Btus of expected base case consumption. By 2000 , the contribution is $.42 \times 10^{15} \mathrm{Btu}$, or $22 \%$ of the total regional gas requirement of $1.85 \times 10^{15}$ Btu. 7

Similarly, if all the refuse were directly fired in utility boilers, the 1985 base case regional coal requirement would be reduced from $3.50 \times 10^{15}$ Btu to 3.27 , or $6.6 \%$, and by 2000 from $8.13 \times 10^{15}$ Dtu LU $7.36 \times 10^{15} \bar{B} t u$, or 9.5 percent.

It can be concluded, therefore, that recovery of energy from refuse can make a significant contribution to the regional energy supply; and, coupled with its environmental, economic and solid waste management benefits, certainly represents an attractive policy option. 
1. OBERS Projection, Series E population; U.S. Water Resources Council, Washington, DC, April 1974.

2. B. S. Edelston and E. S., Rubin, "Current and Future Use of Coal in the Northeast," BNL 50560 (May 1976), Environmental Studies Institute, Carnegie-Mellon University, Pittsburgh, Pennsylvania

3. Edelston and Rubin, Note 2, supra, Tables IV-11 and IV-1B.

4. For further discussion, see R. N. Langlois, "A Perspective on the Energy Future of the Northeast: Natural Gas", Brookhaven National Laboratory, Energy Policy Analysis Division, BNL - 50558, May 1976.

5. Appendix F for status of these plans.

6. As given in J. Brainard, et al., "A Perspective on the Future of the Northeast United States," BNL - 50550, Energy Policy Analysis Division, Brookhaven National Laboratory, May 1976, Appendix B, "Scenario l"

7. Ibid. 
THIS PAGE

WAS INTENTIONALLY

LEFT BLANK 
CHAPTER X

SUMMARY AND CONCLUSIONS

The conclusions of this study can be summarized as follows.

1. The contribution of energy recovered from municipal refuse to the future energy supply of the Northeastern United States, even though representing only 1 to $2 \%$ of total Btu consumption, is significant in terms of potential contribution to particular sectors; by 2000 , refuse could supply as much as $22 \%$ of the total regional demand for natural gas or $9.5 \%$ of that for coal.

2. The high hauling cost of refuse over long distances makes it unlikely that significant quantities of rural waste will be converted to energy because disposal by sanitary landfill will usually be cheaper; therefore at most 90 to $95 \%$ of the total regional refuse energy resource will be economically recoverable.

3. The most attractive energy conversion option is direct firing of refuse in coal-fired utility boilers. Regardless of alternative disposal cost, most urban areas in the Northeast having coal-fired plants would find it economically attractive to burn refuse in it.

4. The generation of steam for industrial process heat in waterwall incinerators is economically attractive if a large industrial user is nearby. Although this condition will doubtless be met in many cases over the next 25 years, this option is unlikely to make a major contribution. Plans for direct firing of municipal refuse in the Northeast already outnumber process steam projects by about 7 to 1 , even though the first major refuse-to-energy project in New England is of the latter type.

5. The options for converting refuse to gas, by either gas pyrulysis or anaerobic digestion with sewage sludge, are economically competitive only under rather special circumstances. Deregulation 
of interstate natural gas prices will make gas conversion more attractive relative to steam generation and direct firing, but the price would have to exceed $300 \mathrm{c} / \mathrm{mcf}$ for the gas option to become more widespread.

6. Given that direct firing in utility boilers is the most attractive option, the extent to which this will in fact be used over the next 25 years depends on two factors. First, the availability of refuse fuel in the urban areas suggests that new coal capacity should also be located in these areas; yet additional mine-mouth plants in Western Pennsylvania are too distant for supplementary refuse firing. Second, the cost of coal to the utilities stands in direct relationship to the amount and price of refuse demanded by utilities; and return to pre-embargo coal prices would invalidate the conclusions reached in this study. 
The energy yield from combustion is readily computed by means of a series of matrix transformations. We assume that the refuse composition does not vary throughout the whole region. Let Column matrix $\mathrm{C}$, of dimension ( $\mathrm{m} \times 1)$, represent the fractional composition of $\mathrm{m}$ categories of refuse. Let $\mathrm{w}$. be a row matrix, of dimension ( $1 \times \mathrm{n}$ ), whose $j$-th element represents the annual gross amount of refuse generated in the $j$-th subregion, in tons/year. Hence the matrix product

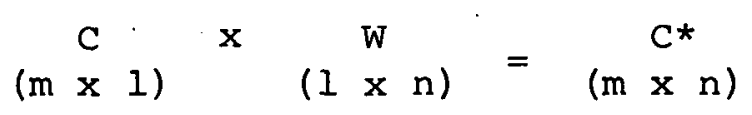

gives the annual amount (in tons/year) of refuse in each of the $m$ categories for each of the $n$ subregions. For example, $c_{i j}{ }^{*}=c_{i} w_{j}$ is the tons of refuse generated each year of $i$-th category in the j-th subregion.

Now let $\mathrm{T}$ be $\mathrm{a} \mathrm{k} \times \mathrm{m}$ matrix corresponding to the transformation from $\mathrm{m}$ refuse categories to $\mathrm{k}$ ultimate analysis categories. The element $T_{i j}$ thus represents the amount of element $i$ contained in refuse category $j .1$ In this study, we shall use the 7 ultimate analysis categories and matrix $\mathrm{T}$ shown in Table 21 . For example, $\mathrm{T}_{23}=0.059$ means that hydrogen forms $5.9 \%$ of garden component of refuse.

Thus, the matrix product

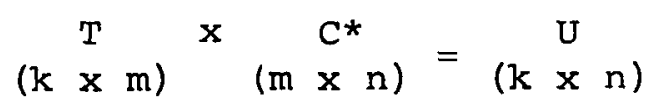

represents the annual amount (in tons/year) of each element of $\mathrm{k}$ ultimate analysis categories in each of the $n$ subregions. Table 22 shows some typical values of $u$ for the Northeast. 
The heat value of refuse may be computed directly from ultim analysis using an equation derived by wilson. 2 Using basic thermuchemical principles, and assuming complete combustion, the heat content, in $B t u / I b$, may be given as

$$
=14096 \mathrm{C}+64678 \mathrm{H}-5950 \mathrm{O}+3982 \mathrm{~S}+1040 \mathrm{~N}
$$

where $\mathrm{C}, \mathrm{O}, \mathrm{H}, \mathrm{N}$, and $\mathrm{S}$ are the fractions of total carbon, total oxygen, total hydrogen, total nitrogen, and total sulfur found on ultimate analysis. However, this heat value will be reduced due to molsture in the refusc, if $\mathrm{h}_{\mathrm{v}}$ is the energy required to heat and vaporize moisture, in Beu/lb, tliels llie net valuc, per lb of refuse as received, is

$$
=14096 \mathrm{C}+64678 \mathrm{H}-5959 \mathrm{O}+1040 \mathrm{~N}+3982 \mathrm{~s}-\mathrm{kvH}_{2} \mathrm{O}
$$

Table 21
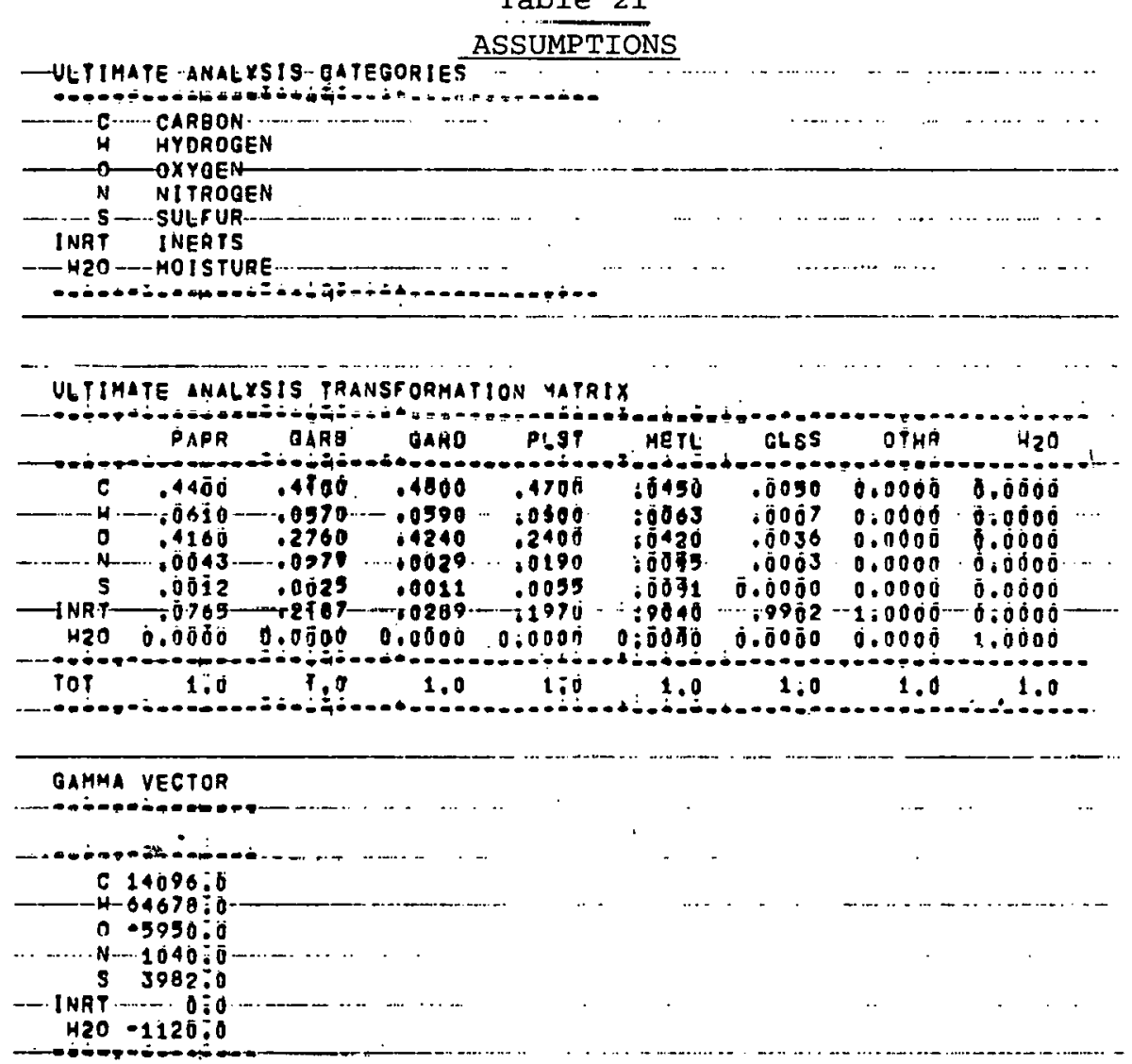

HEAT VALUE OF COAL: $1202000,8 T U / L B$

-HEAT.-AATE-D-..... 10665,0,8TU/KW4R

AVE.LOAD.FACTOR . .600 
Table 22

ULTIMATE ANALYSIS, TONS/YR

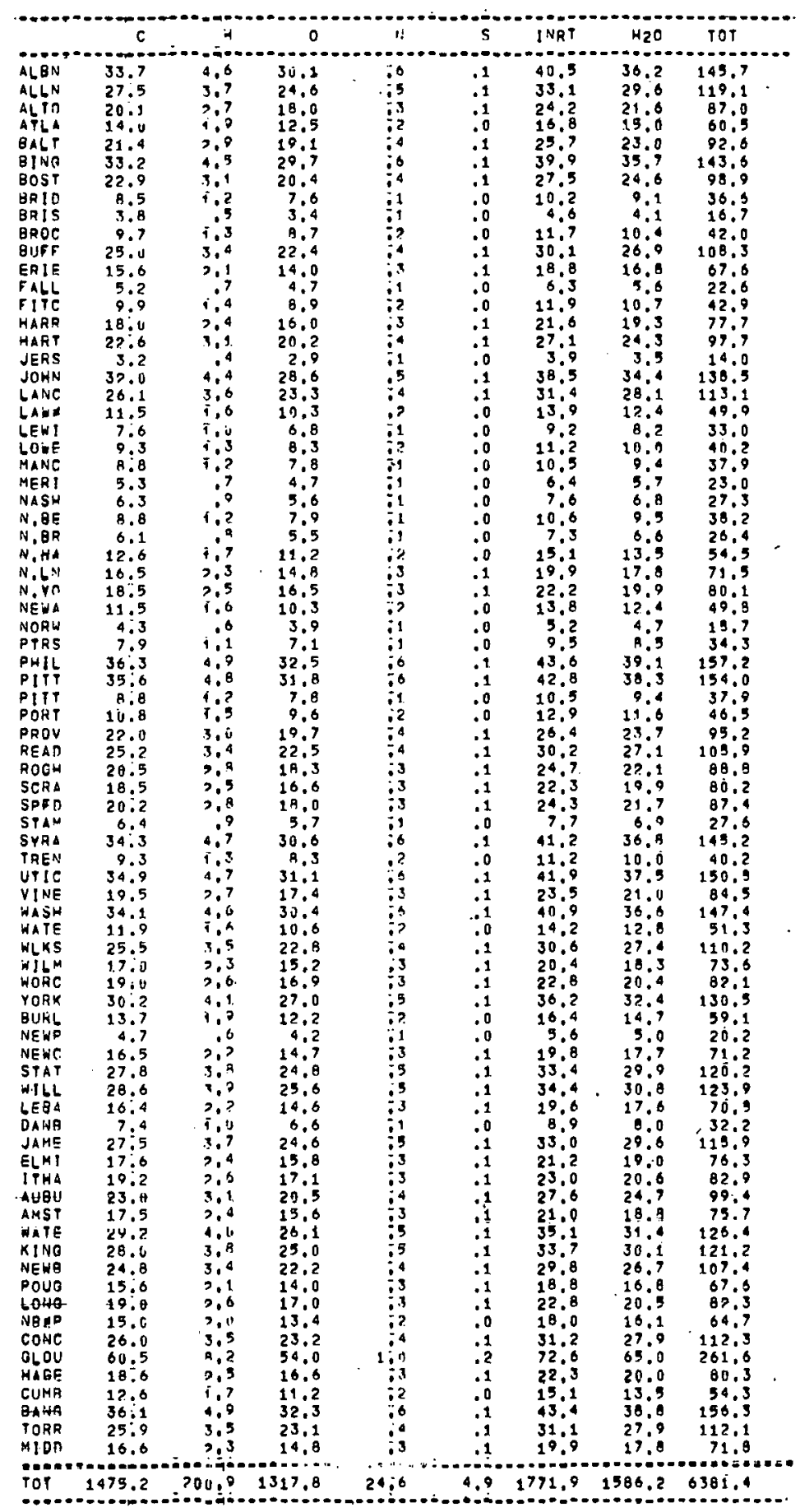


One may thus compute the annual energy yield

$$
\begin{aligned}
& \mathrm{B}_{\mathrm{T}}=\frac{2000}{10^{12}} \mathrm{x} \quad \gamma \quad \mathrm{x} \quad \mathrm{u} \\
& \left(\begin{array}{ll}
1 \times n)(1 \times 1)(1 \times k)(k \times n)
\end{array}\right.
\end{aligned}
$$

where

$$
Y=\left[14096,64678,-5950,1040,3982,0.0,-k_{v}\right]
$$

and $B_{T}$ is an $(1 \times n)$ matrix. Each element of $B_{T}$ represents the annual energy yieln in $10^{12}$ Btu/year, of each of the $n$ subregions. Inserting a value of $k=-1120,{ }^{3}$ the full $\gamma$-vector, as used in the computer model, is shown in Table 21 .

Since refuse composition varies from year to year, as indicated by historical trend, the heat content of raw refuse (in $B t u / 1 b$ ) for a particular year is also of interest. Let $\mathrm{V}$ be $\mathrm{a}(1 \mathrm{x} t)$ matrix whose j-th element is the heat content of raw refuse in year $j$. Let matrix $D$, of dimension ( $\mathrm{m} x t$ ) whose transpose is shown in Table 4 , represent the dry weight composition of $t$ years. Thus

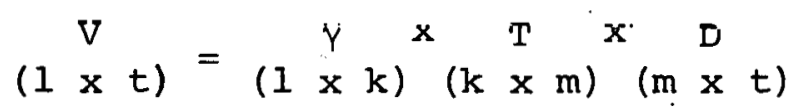

and elements of $\mathrm{V}$ are sometimes referred to as "As received heal values."

$$
\text { NOTES TO APPENDIX A }
$$

1. Clearly, this definition results in column sums of unity, i.e.,

$$
\sum_{j=1}^{k} t_{j i}=1
$$

2. D. L. Wilson, "Predietion of Heat of Combustion of solin Woatco from Ultimate Analysis", Environmental Science and Technology, Vo1. 6, No. 13, p. 1119 (December 1972).

3. See e.g., Envirogenics Company, "Systems Evaluation of Refuse as a Low Sulfur Fuel", Vol. 1, P. II-48. 
APPENDIX B. DERIVATION OF SOLID WASTE GENERATION EQUATION

Let the amount of refuse $q^{\prime}(r)$, in $1 b$ capita/day, generated at distance $r$ from the center of the city be a function of population density at that point, i.e.

$$
\dot{q}^{\prime}(r)=q_{0}[d(r)]^{\beta}
$$

where $q_{0}$ and $\beta$ are constants, and $d(r)$ is the population density (persons/sq.mi.) at distance $r$ from the city center. According to the exponential model for urban population density, ${ }^{2}$

$$
d(r)=d_{0} e^{-\alpha r}
$$

where $d_{0}$ is the population density at the center of the city, $\alpha$ the density gradient $\left(\mathrm{mile}^{-1}\right)$, and thus

$$
q^{\prime}(r)=q_{0} d_{0}^{\beta} e^{-\alpha \beta r}
$$

It follows that $q(r)$, the amount of refuse generated per square mile per year at distance $r$ from the city center, is given by

$$
\begin{aligned}
q(r) & =\frac{365}{2000} q^{\prime}(r) d(r) \\
& =0.1825 q_{0} d_{0}^{1+\beta} e^{-\alpha(1+\beta) r}
\end{aligned}
$$

where $q(r)$ is in tons/sq.mi./year. 
Hence, if

$$
\begin{aligned}
& a^{\prime}=\alpha(1+\beta) \\
& a=0.1825 q_{0} a_{0}^{1+\beta}
\end{aligned}
$$

Eq. [12] can be written as

$$
q(r)=a e^{-\alpha^{\prime} r}
$$

To obtain the total quantity of solid waste generated in a vity of sector anglc $\theta, 3$ one must integrate Fi. [ [ 13] over appriprate limits. The quantity $Q(R)$ (tons/year), generated in a city of radius $R$, can be stated as ${ }^{4}$

$$
\begin{aligned}
Q(R) & =\int_{r=0}^{R} \int_{\theta=0}^{\theta} q(r) r d r d \theta \\
& =a \theta \int_{0}^{R} e^{-\alpha ' r} r d r \\
& =\frac{a \theta}{\alpha^{\prime^{2}}}\left[1-\left(I+\alpha^{\prime} R\right) e^{-\alpha^{\prime} R}\right]
\end{aligned}
$$




\section{NOTES TO APPENDIX B}

1. Refuse generation may of course be a function of more variables than only population density, but for a given city population density is the best explanatory variable for describing intra-city variations in generation rate. Evidently population density is a good surrogate for other important variables such as household income.

2. The exponential model for urban population density is discussed in detail in P. M. Meier and T. H. McCoy, "An Analytical Approach to the Determination of Urban Population Density Gradients and its Application to Energy Planning Problems", BNL - 20916, Policy Analysis Division, Brookhaven National Laboratory, January 1976 .

3. Ibid., Chapter III.

4. Ibid. 
APPENDIX C. DERIVATION OF HAUL COST EQUATIONS

Case 1. Destination at Center of City, Haul in Collection Vehicle

Transportation costs for house-to-house refuse collection

vehicles are generally given in terms of $\$$ /hour to operate a truck of given capacity. The haul cost per trip is thus

$$
\gamma_{h}\left(\frac{2 r}{s}+u\right)
$$

, where ${ }{ }_{h}=$ cost, $\$ /$ hour

$$
r=\text { haul distance, miles }
$$

$\mathbf{s}=$ average truck speed, miles/hour

$u=$ unloading time, hours

and hence the cost per ton, as a function of haul distance, is

$$
\frac{\gamma_{h}}{t}\left(\frac{2 r}{s}+u\right)
$$

where $t$ is the truck capacity in tons.

Therefore, with Eq. [13] used to obtain the amount of refuse generated (tons/sq.mi./Yr), the hanl cost in $\$ / \mathrm{sq} \cdot \mathrm{mi} \cdot /$ year at distance $r$ from the center is

$$
\begin{aligned}
c(r) & =\frac{\gamma_{h}}{t}\left(\frac{2 r}{s}+u\right) q(r) \\
& =\frac{\gamma_{h}}{t}\left(\frac{2 r}{s}+u\right) a e^{-\alpha^{\prime} r} \\
& =\frac{2 a \gamma_{h}}{t s} r e^{-\alpha^{\prime} r}+\frac{a u \gamma_{h}}{t} e^{-\alpha^{\prime} r}
\end{aligned}
$$


If one assumes a circular city of sector angle $\theta,{ }^{1}$ then the total haul cost per year for the area within radius $R$ is

$$
C(R)=\int_{0}^{R} c(r) r \theta d r
$$

Substitution of Eq. [15] into Eq. [16] gives

$$
\begin{aligned}
C(R) & =\int_{0}^{R}\left[\left(\frac{2 a r h}{t s}\right) r e^{-\alpha^{\prime} \cdot r}+\left(\frac{a u \gamma_{h}}{t}\right) e^{-\alpha^{\prime} r}\right] r \theta d r \\
& =\frac{2 a \theta r}{t s} \int_{0}^{R} r^{2} e^{-\alpha^{\prime} r} d r+\frac{a u r_{h}}{t} \int_{0}^{R} r e^{-\alpha^{\prime} r} d r
\end{aligned}
$$

By further algebra omitted here, this integral can be shown to yield

$$
\begin{aligned}
C(R)= & \frac{2 a \theta h}{\operatorname{ts}^{\prime}}\left[2-\left(2+2 \alpha^{\prime} R+\alpha^{2} R^{2}\right) e^{-\alpha^{\prime} R}\right] \\
+ & \frac{\operatorname{au} \theta \frac{\gamma}{2}}{t \alpha \cdot}\left[1-\left(1+\alpha^{\prime} R\right) e^{-\alpha^{\prime} R}\right]
\end{aligned}
$$

the systemwide cost.per ton, $\mathrm{C}_{\mathrm{s}}$, of collecting all refuse within radius $R$ and delivering it to the center of the city, is given by

$$
C_{S}(R)=\frac{C(R)}{Q(R)}
$$


hence

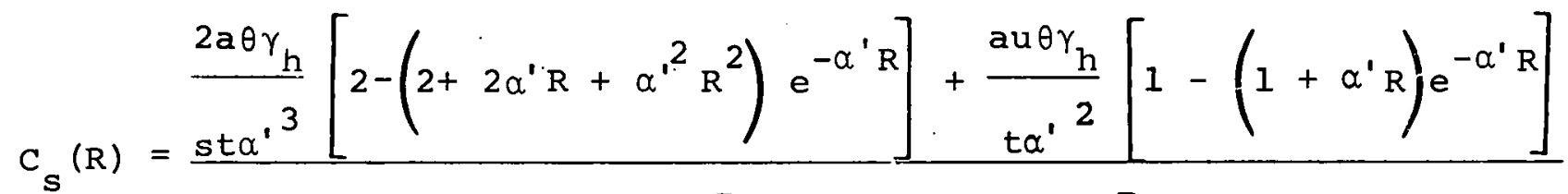

$$
\begin{aligned}
& \frac{a \theta}{\alpha^{\prime 2}}\left[1-\left(1+\alpha^{\prime} R\right) e^{-\alpha^{\prime} R}\right]
\end{aligned}
$$

Which simplifies to

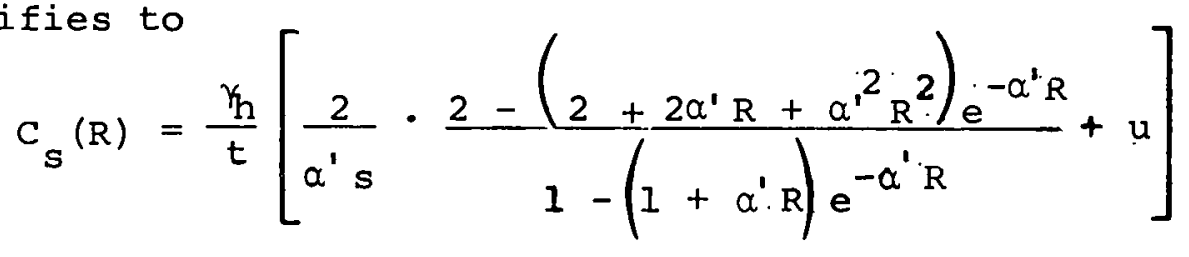

Case 2. Arbitrary Destination: Haul in Collection Vehicle Consider destination $P$, a distance $l$ from the center of a circular SMSA, as shown in Figure 18. 'Note that

$$
r^{\prime 2}=r^{2}+e^{2}-2 r l \cos \theta
$$

The amount of refuse generated per unit area is given by Eq. [13] as

$$
q(r)=a e^{-\alpha^{\prime} r}
$$

hence the haul cost per unit area at point $(r, \theta)$ is $^{2}$

$$
\begin{aligned}
c(r, \theta) & =\frac{\gamma_{h}}{t}\left(\frac{2 r^{\prime}}{s}+u\right) q(r) \\
& =\frac{\gamma_{h}}{t}\left[\frac{2}{s}\left(r^{2}+l^{2}-2 r l \cos \theta\right)^{\frac{1}{2}}+u\right] q(r)
\end{aligned}
$$




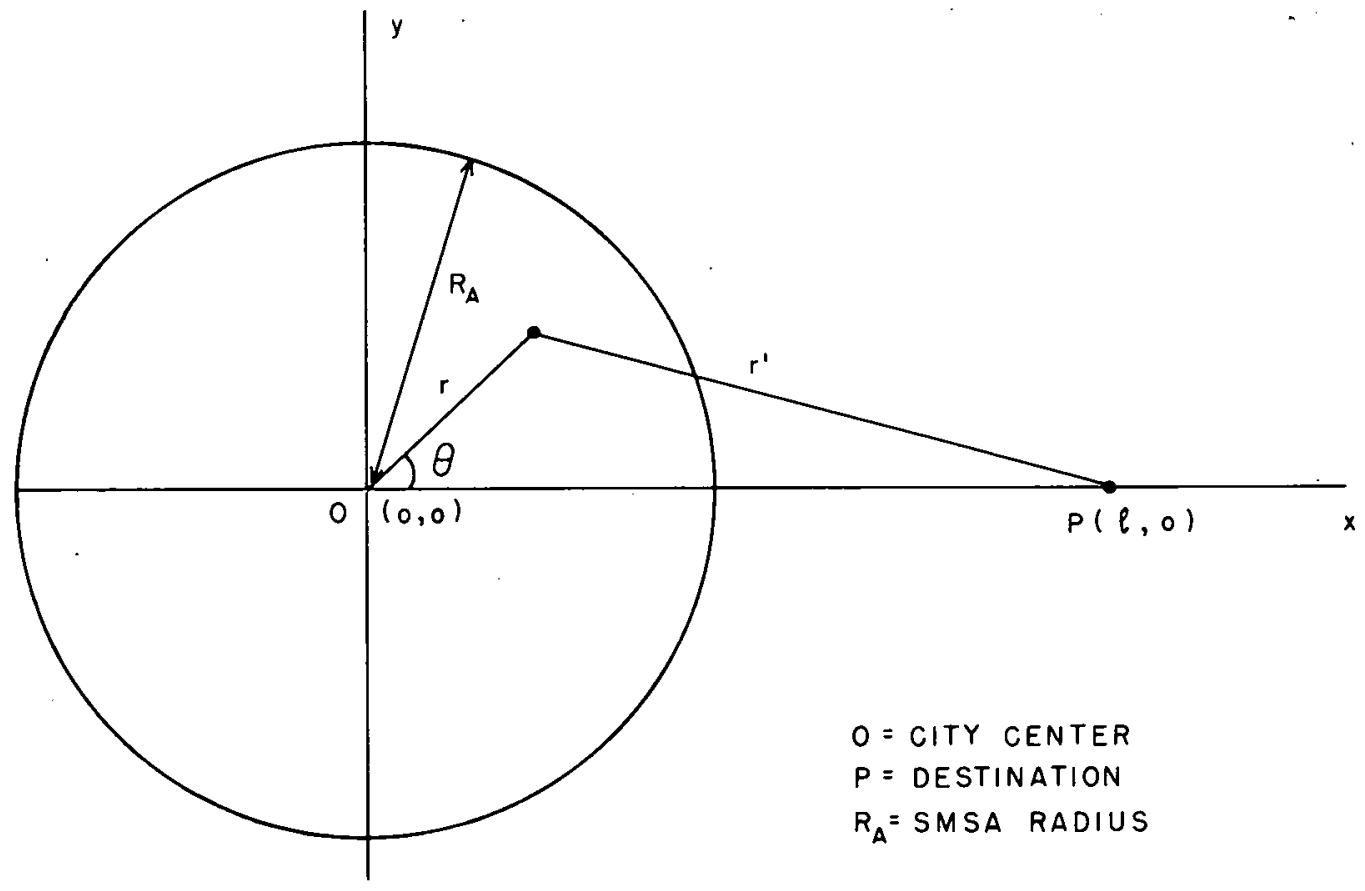

Figure 18. Definition sketch for an arbitrary destination.

The total average system haul cost is given by

$$
\begin{aligned}
& c_{s}(R)=\frac{\int_{r=0}^{R} \int_{\theta=0}^{2 \pi} d(r, \theta) r d r d \theta}{\int_{r=0}^{R} \int_{\theta=0}^{2 \pi} q(r) r d r d \theta} \\
& =\frac{2 \gamma_{h}}{t s} \cdot \frac{\int_{r=0}^{R} \int_{\theta=0}^{2 \pi}\left(r^{2}+e^{2}-2 r l \cos \theta\right)^{\frac{1}{2}} q(r) r d r d \theta}{\int_{r=0}^{R} \int_{\theta=0}^{2 \pi} q(r) r d r d \theta}+\frac{\gamma_{h}}{t} u
\end{aligned}
$$


but, from Eq: [13],

$$
q(r)=a e^{-\alpha^{\prime} r}
$$

hence

$$
\int_{r=0}^{R} \int_{\theta=0}^{2 \pi} q(r) r d r d \theta=\frac{2 \pi a}{\alpha^{\prime 2}}\left[1-\left(1+\alpha^{\prime \prime R}\right) e^{-\alpha^{\prime} R}\right]
$$

and

$$
\begin{aligned}
& \int_{r=0}^{R} \int_{\theta=0}^{2 \pi}\left(r^{2}+l^{2}-2 r \ell \cos \theta\right)^{\frac{1}{2}} q(r) r d r d \theta \\
= & 2 a \int_{0}^{R} r e^{-\alpha^{\prime} r} d r \int_{0}^{\pi}\left(r^{2}+l^{2}-2 r \ell \cos \theta\right)^{\frac{1}{2}} d \theta
\end{aligned}
$$

the integral

$$
I=\int_{0}^{\pi}\left(r^{2}+\ell^{2}-2 r \ell \cos \theta\right)^{\frac{1}{2}} d \theta
$$

can be solved by introducing the change of variable

$$
\xi=\frac{\pi}{2}-\frac{\theta}{2}
$$

It can be shown that Eq. [19] reduces to

$$
\begin{gathered}
I=2(r+\ell) \int_{0}^{\pi / 2}\left(1-\frac{4 r \ell}{(r+\ell)^{2}} \sin \zeta\right)^{\frac{1}{2}} d \zeta \\
=2(r+\ell) E\left(\frac{2 \sqrt{r \ell}}{r+\ell}\right) \\
-140-
\end{gathered}
$$


$: E\left[2 \sqrt{r^{l}} /(r+\ell)\right]$ is a complete elliptical integral of the scuuld kind, ${ }^{3}$ for which numerical integration. routines are available at most large scientific computer facilities. Thus Eq. [18a] san be written

$$
I=4 a \int_{0}^{R} r(r+\ell) e^{-\alpha^{\prime} r} E\left(\frac{2 \sqrt{r \ell}}{r+\ell}\right) d r
$$

vhich can be solved numerically. Hence

$$
\begin{aligned}
C_{s}(R) & =\frac{2 \gamma_{h}}{t s} \cdot \frac{4 a \int_{0}^{R} r(r+l) e^{-\alpha^{\prime} r} E\left(\frac{2 \sqrt{r l}}{r+l}\right) d r}{\frac{2 \pi a}{\alpha^{2}}\left[1-\left(1+\alpha^{\prime} R\right) e^{-\alpha^{\prime} R}\right]}+\frac{\gamma_{h}}{t} u \\
& =\frac{4 \gamma_{h}^{\alpha^{\prime}}}{\pi t s} \cdot \frac{\int_{0}^{R} r(r+l) e^{-\alpha^{\prime} r} E\left(\frac{2 \sqrt{r l}}{r+l}\right) d r}{1-\left(1+\alpha^{\prime} R\right) e^{-\alpha^{\prime} R}}+\frac{\gamma_{h}}{t} u
\end{aligned}
$$

Note that for the special case $l=0$, this reduces to Eq. [18], and that Eq. [21] is valid for any $l$, within or outside $R_{A}$. zase 3. Transfer Station Case

As the distance from population center to haul destination increases, the cost of transporting refuse in the vehicle used for rouse-to-house collection increases. At some break-even distances, it becomes cheaper to build a transfer facility near the population zenter and to haul refuse from there to the disposal (or energy cecovery) site in large tractor-trailers.

such a system is diagrammed in Figure 19. Haul cost to the transfer station in collection vehicles is given by Eq. [21]. To this must be added the haul cost from transfer station to disposal 


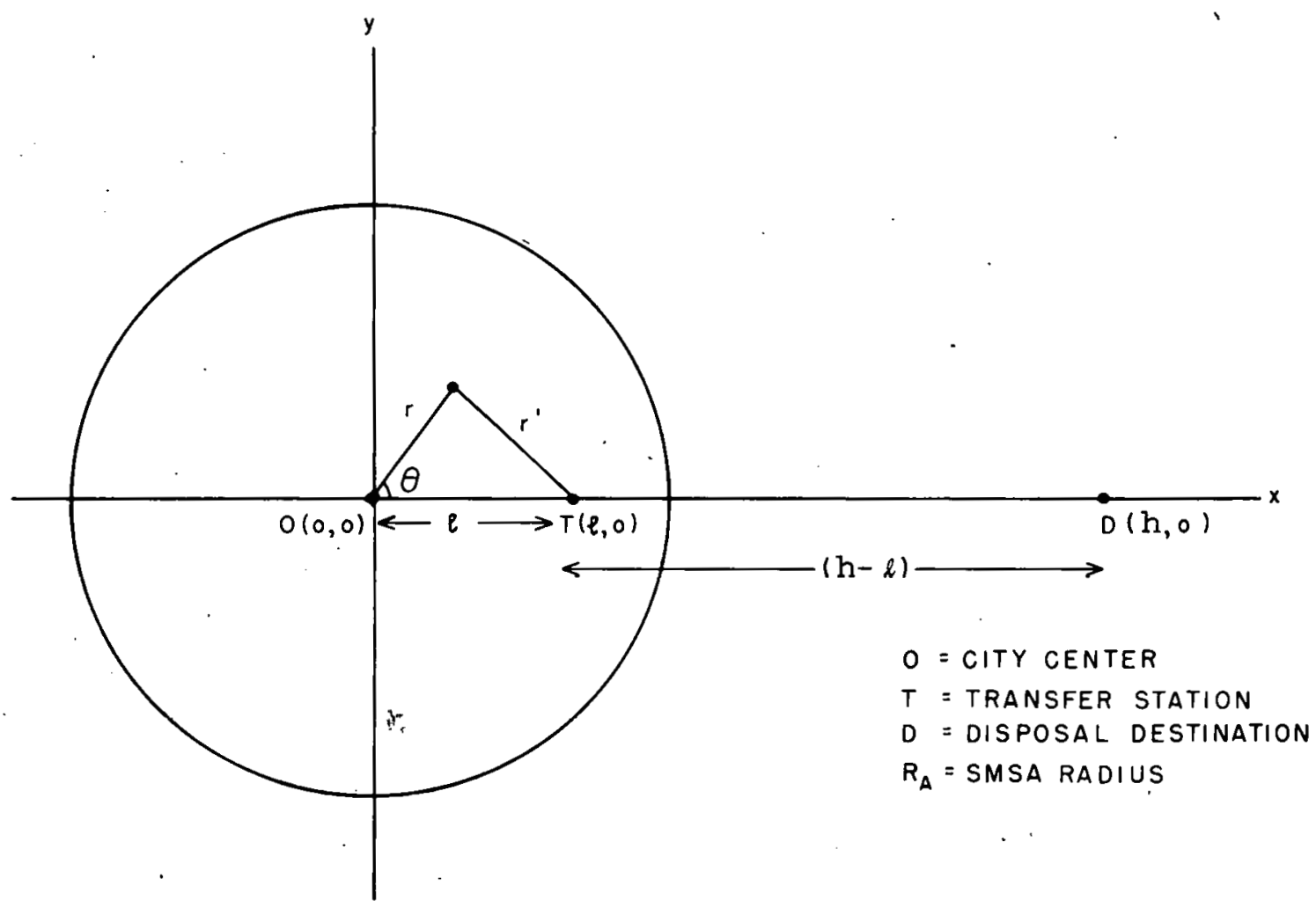

Figure 19. Definition sketch, transfer station case.

site, given by

$$
\frac{y^{*}}{t^{*}}\left[\frac{2(h-\ell)}{s^{*}}+u^{*}\right]
$$

where $\gamma^{\star}=$ cost, $\$$ /hour

$$
\begin{aligned}
& t^{*}=\text { truck capacity, tons } \\
& \mathbf{s}^{*}=\text { speed, miles/hour } \\
& u^{*}=\text { loading and unloading time, hours }
\end{aligned}
$$

This is analogous to Eq. [15], with the asterisk indicating reference to a transfer vehicle rather than a collection vehicle 
that $u$ * includes both loading and unloading time whereas $u$. cluaed only unloading time).

The capital cost of the transfer facility must also be condered. The cost of processing a ton of refuse at a transfer ation, $\mathrm{C}_{\mathrm{T}}$, can be expressed 4

$$
\mathrm{C}_{\mathrm{T}}=\mathrm{b} / \mathrm{T}^{\mathrm{m}}
$$

ere $b$ and $m$ are constants characteristic of the station design a construction costs, and $\mathrm{T}$ is the transfer station capacity in is/day. If $T$ is in the range 100 to 1500 , then $b=33.4$ and $0.55,5$ and hence the average cost per ton for a transfer station cving a city of redius $R$ is

$$
C_{T}=\frac{33.4}{[Q(R) / 260]^{0.55}}
$$

ere $Q(R)$, in tons/year, is given by Eq. [14] and 260 represents cking days per year. The total cost for delivering refuse to transfer station, transfering it, and hauling it to the desation point is given by

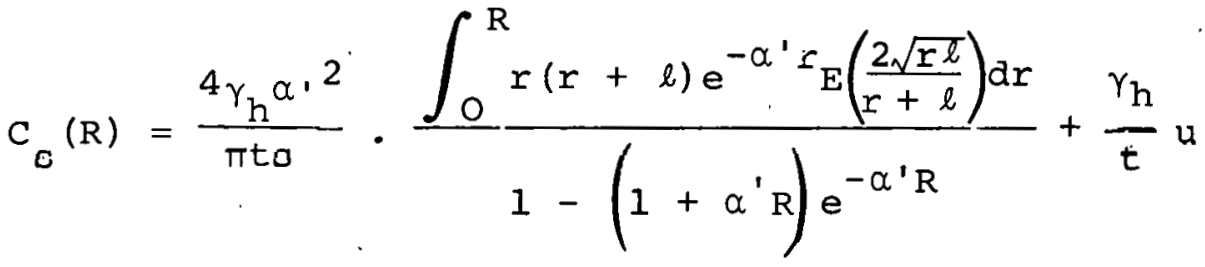

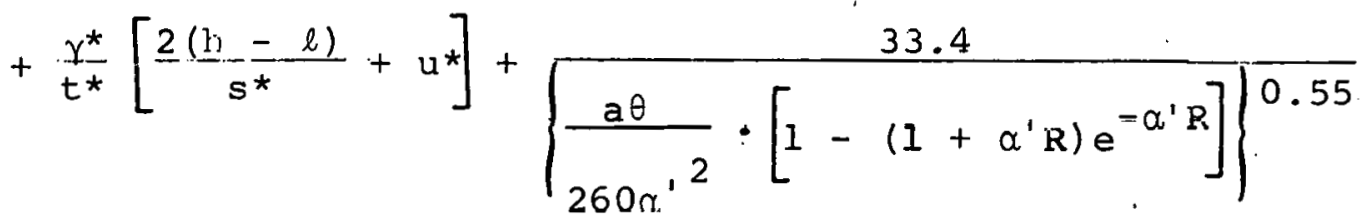




\section{NOTES TO APPENDIX C}

1: For an explanation of this assumption, see P. Meier and T. $\pi$. Mccoy, "An Analytical Approach to the Determination of

Urbàn Population Density Gradients and its Application to Ener Planning Problems", BNL 20916 , Policy Analysis Division, Brookhaven National Laboratory.

2. Ibid, Chapter III.

3. An Elliptical integral of the second kind is defined as the general form

$$
E(x)=\int_{0}^{\varphi}\left(1-x^{2} \sin ^{2} \varphi\right)^{\frac{1}{2}} d \varphi
$$

if $\varphi_{0}=\pi / 2, E(X)$ id alled a complete elliptical integral (of the second kind).

4. A. D. Little, Inc. "A Systems Evaluation of Alternative Statewide Resource Recovery Techniques for the disposal of Municipa Solid Waste" Report to the Massachussetts Department of Public Works, December 1973 , p. 118.

5. Ibid, p. 119 . 
APPENDIX D: DETERMINATION OF THE OPTIMAL DELIVERY DISTANCE TO AN ENERGY RECOVERY FACILITY

Let the total annual cost of refuse haul, disposal, and energy conversion be given by

$$
y=-Q(R) P_{R}+\left[Q_{T}-Q(R)\right] \cdot P_{D}+C(R)
$$

vhere the first term represents revenue from energy conversion, the second, cost of disposing of the residual refuse; and the third; laul cost to the energy facility; and

$$
\begin{aligned}
Q(R) & =\text { refuse converted to energy, tons/year } \\
Q_{T} & =\text { total refuse in the region, tons/year } \\
P_{R} & =\text { breakeven refuse price, } \$ / \text { ton } \\
P_{D} & =\text { alternative refuse disposal cost, } \$ / \text { ton } \\
C(R) & =\text { cost of refuse delivery to conversion facility }
\end{aligned}
$$

ince minimization of $y$ is the objective, differentiating Eq. [22 ] jith respect to $R$, setting the result to zero, and solving for $R$ illl yield the optimum distance (and hence, the amount of refuse ptimally converted):

$$
\begin{gathered}
\frac{d y}{d R}=-P_{R} \frac{d Q(R)}{d R}-P_{D} \frac{d Q(R)}{d R}+\frac{d C(R)}{d R}=0 \\
\left(P_{R}+P_{D}\right) \frac{d Q(R)}{d R}=\frac{d C(R)}{d R}
\end{gathered}
$$


From Appendix B

$$
\frac{d Q(R)}{d R}=a \theta R e^{-\alpha R}
$$

and from Appendix $\mathrm{C}$

$$
\frac{\mathrm{dC}(\mathrm{R})}{\mathrm{dR}}=a \theta \mathrm{R} \mathrm{e}^{-\alpha^{\prime} \mathrm{R}} \cdot \frac{\gamma_{h}}{\mathrm{t}}\left(\frac{2 \mathrm{R}}{\mathrm{s}}+\mathrm{u}\right)
$$

Substituting into Eq. [23] gives

$$
\left(P_{R}+P_{D}\right) a \theta R e^{-\alpha^{\prime} R}=a \theta R e^{-\alpha^{\prime} R} \cdot \frac{\gamma}{t}\left(\frac{2 R}{s}+u\right)
$$

hence

$$
P_{R}+P_{D}=\frac{\gamma_{h}}{t}\left(\frac{2 R}{s}+u\right)
$$

Thus, $R$ is the distance for which the haul cost equals alternative disposal cost plus breakeven refuse price and can be written as

$$
R=\frac{\operatorname{ts}\left(P_{R}+P_{I}\right)}{2 \gamma_{h}}-\frac{u s}{2}
$$


Appendix E

FOSSIL FUELED UNITS IN THE NORTHEAST

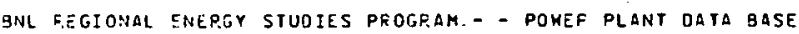

FOSSIL-FUELFO UNITS, NOZTHEAST U.S.

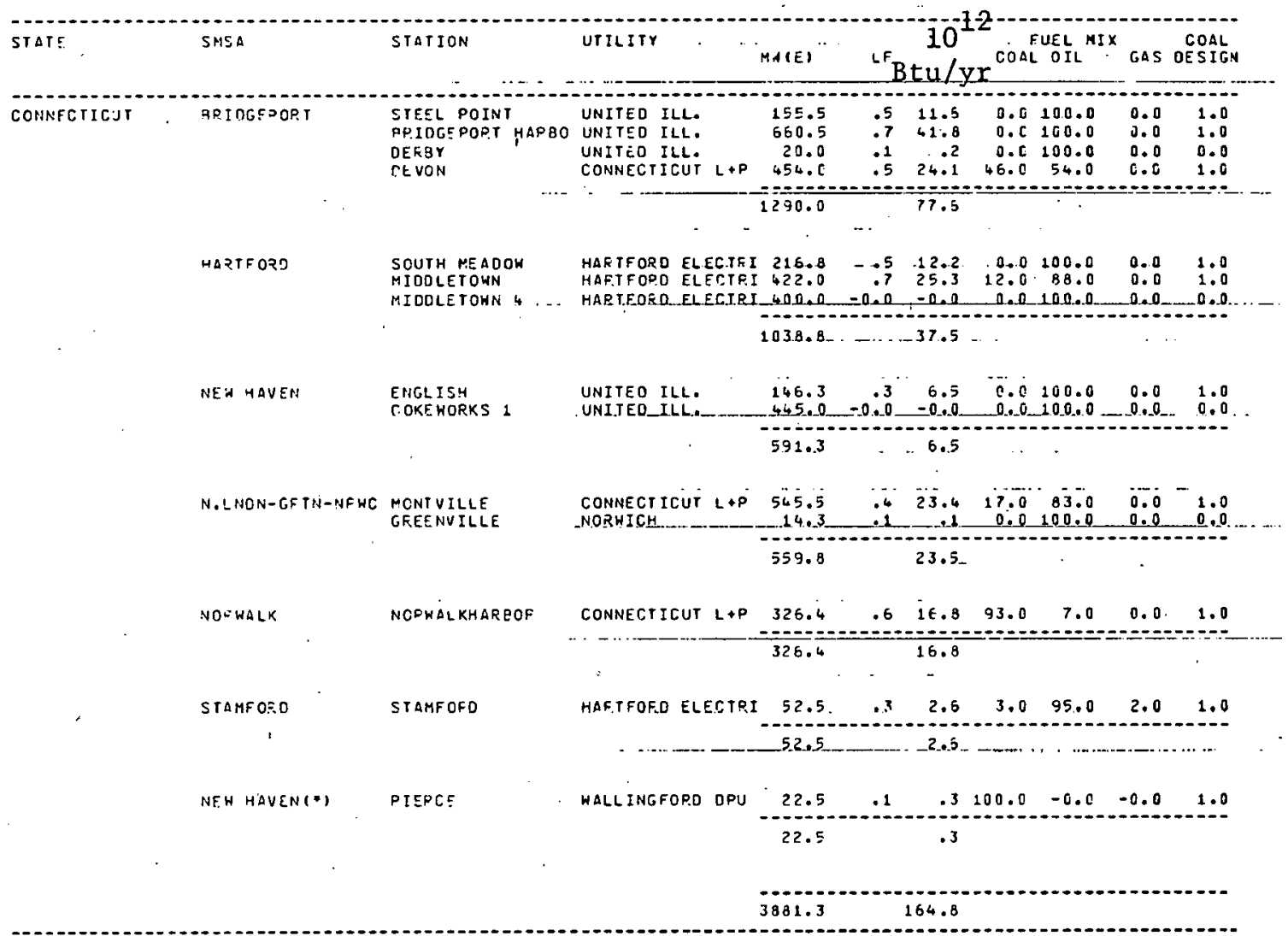




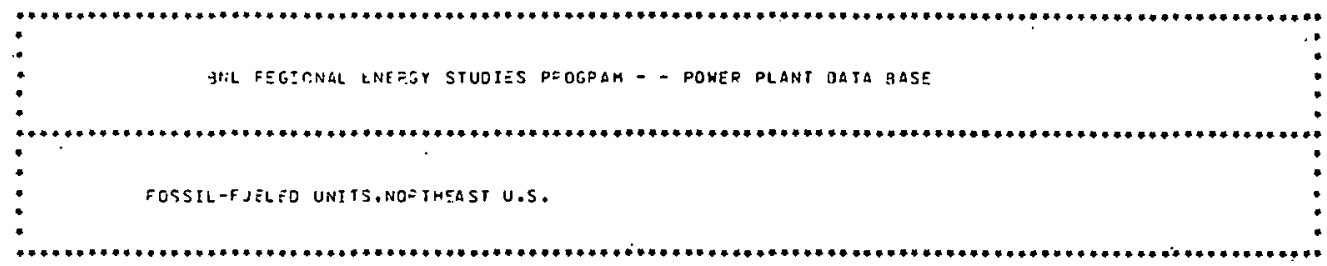

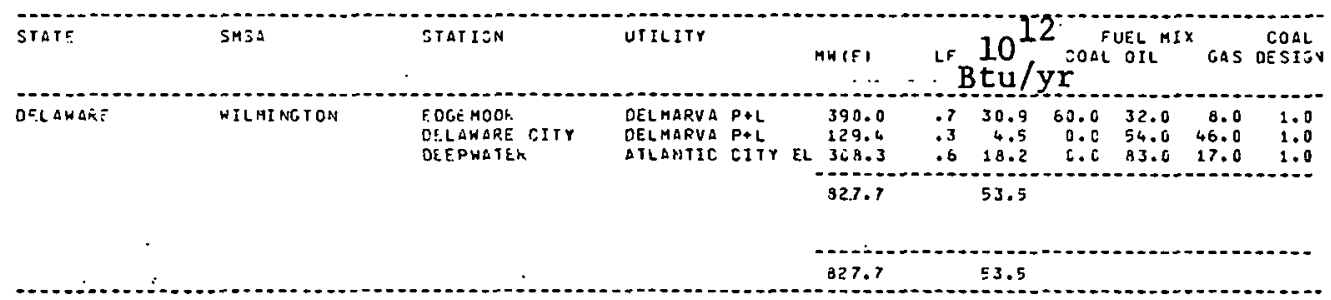

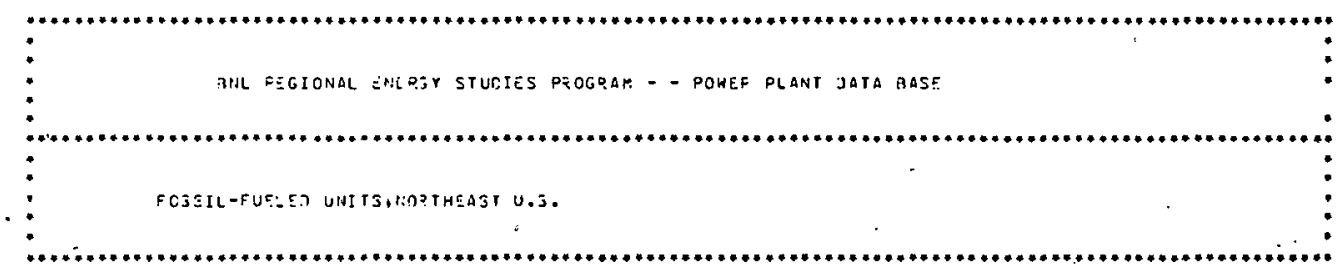

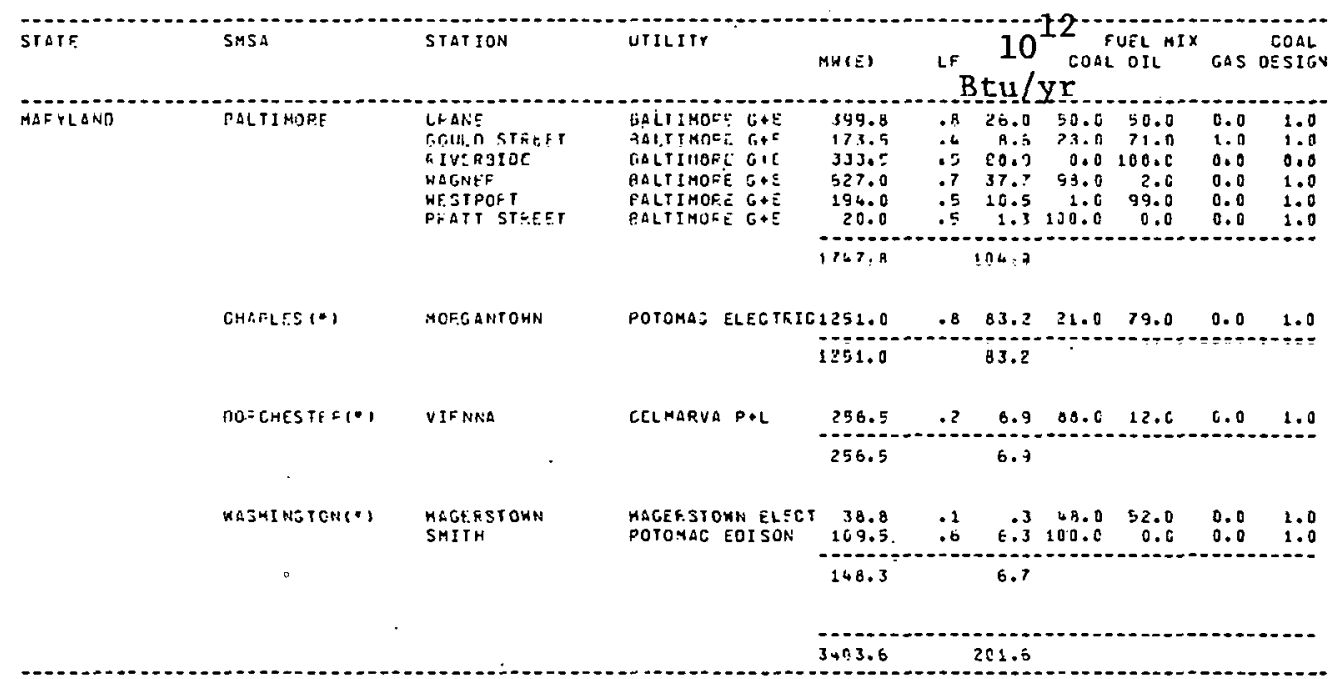




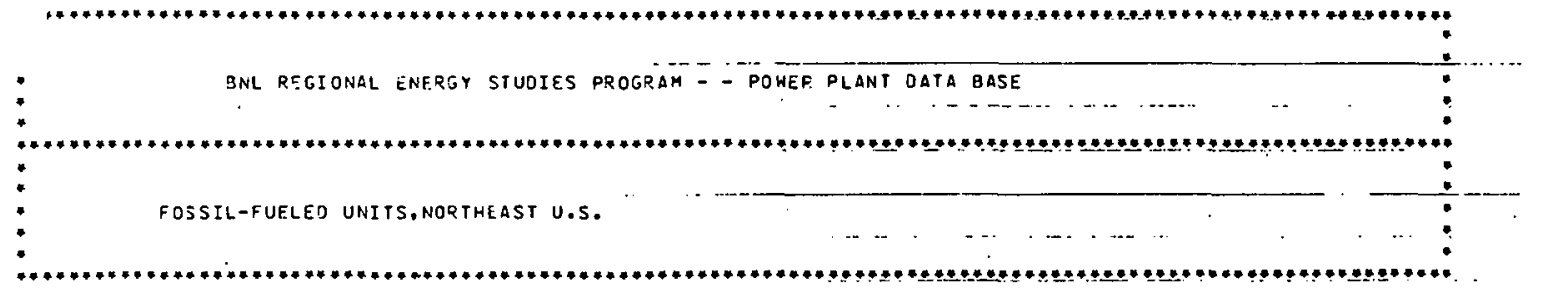

STATE

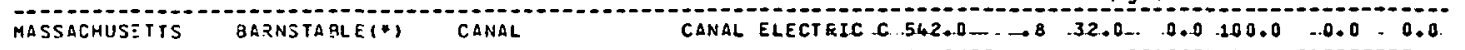

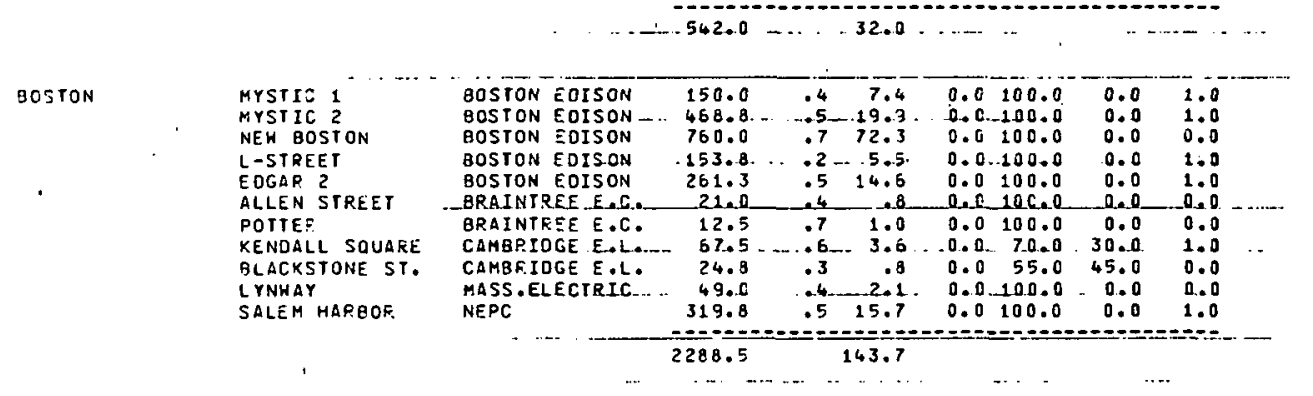

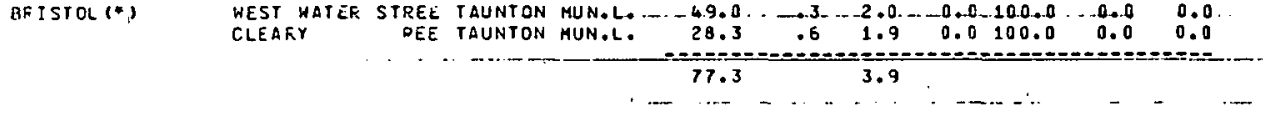

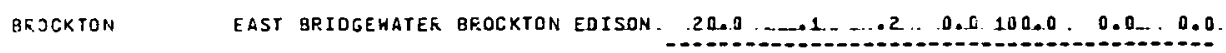
20.00

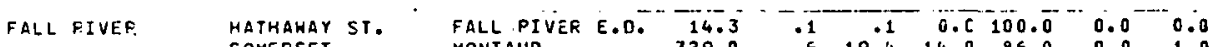

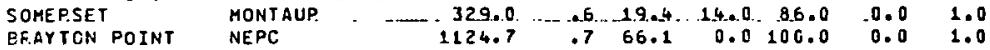
$\frac{1.640 .7}{1468.0}$

FITCHBUFG-LEOHIN FITCHBURG

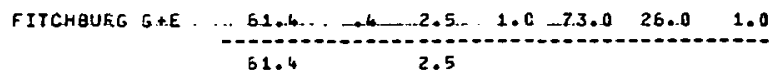

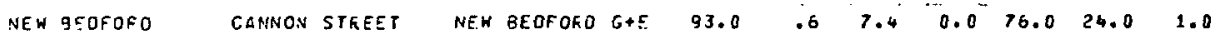

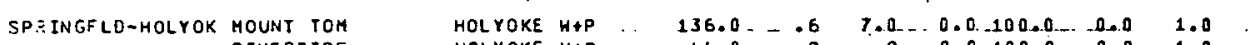

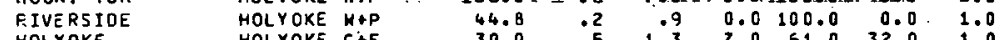

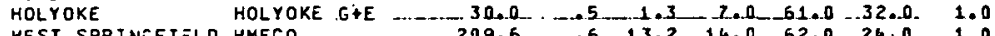
HEST SPRINGFIELD HMECO 209,6 .6 $13 . ? 16.067 .024: 0$ 2.0 $420.4 \quad \frac{22.4}{22}$ -..

WOPCESTEF WEBSTER STREET MASS. ELECTRIC . $34.5, .5 .1 .291 .6-9.0$. 0.0 .1 .0$. 34.5 -

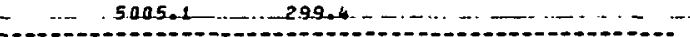


BNL fegional ENERjY STUdies progran - - POHER Plant data base

FOSSIL-FUELED UNITS, MOPTHEAST U.S.

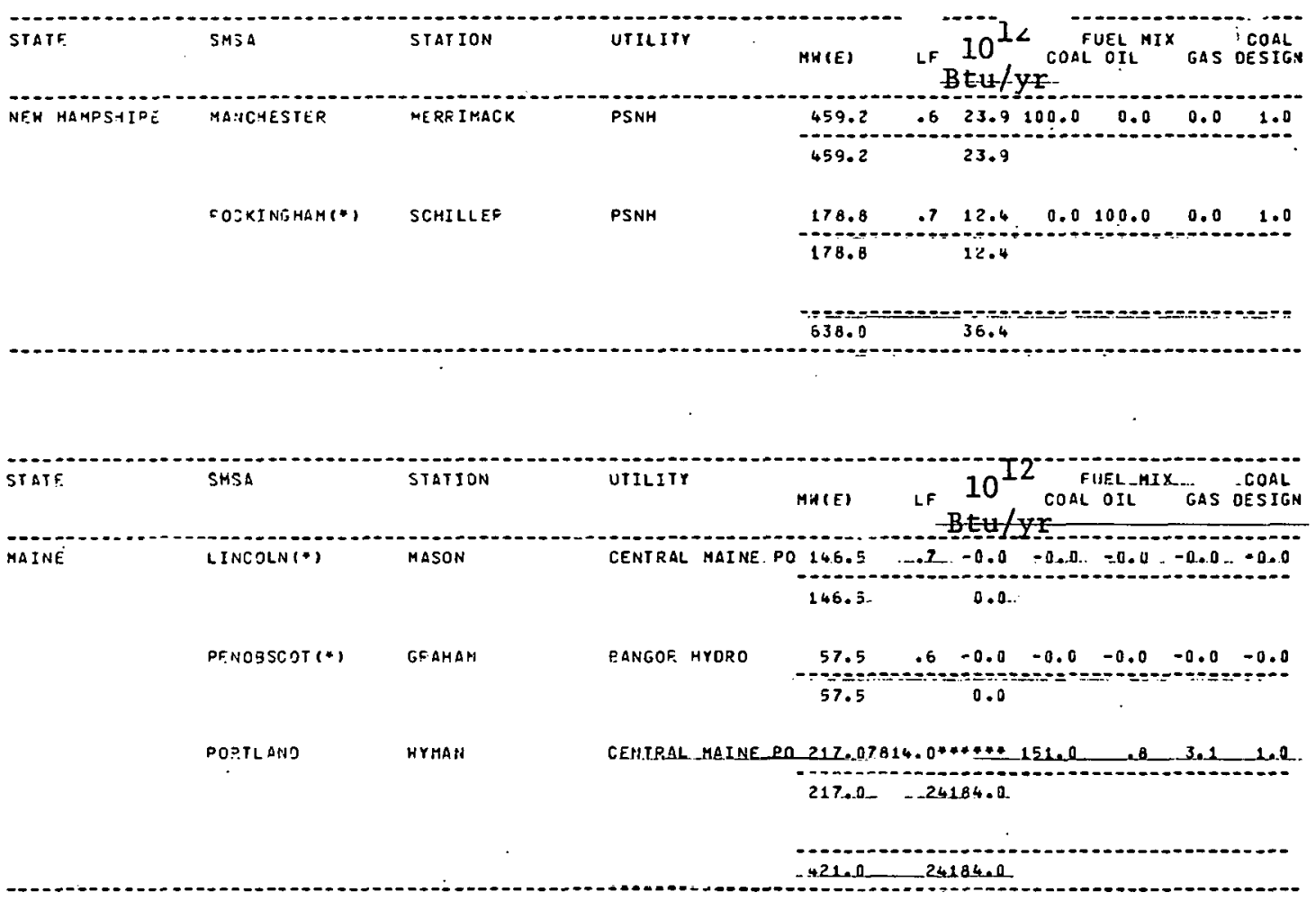




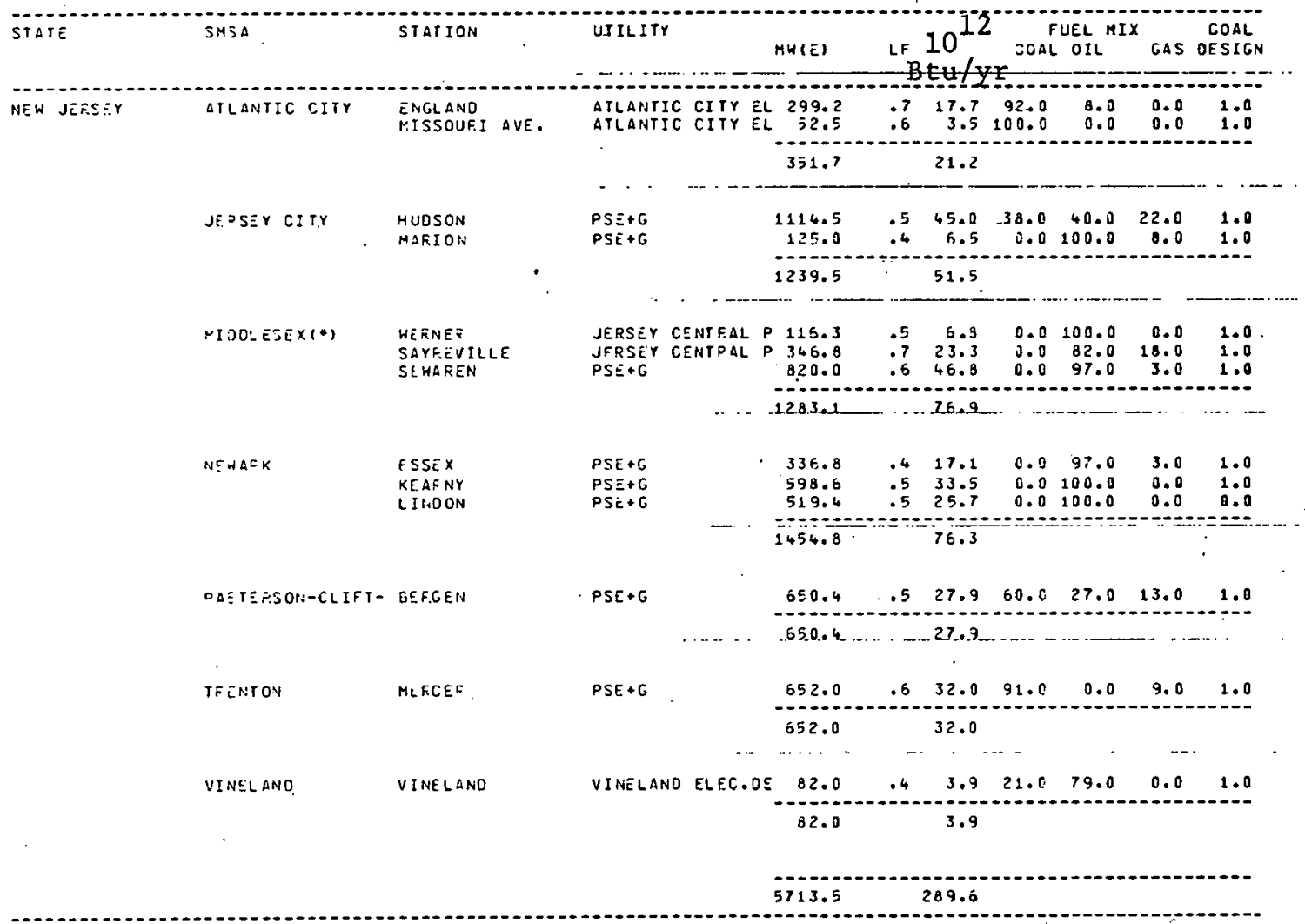




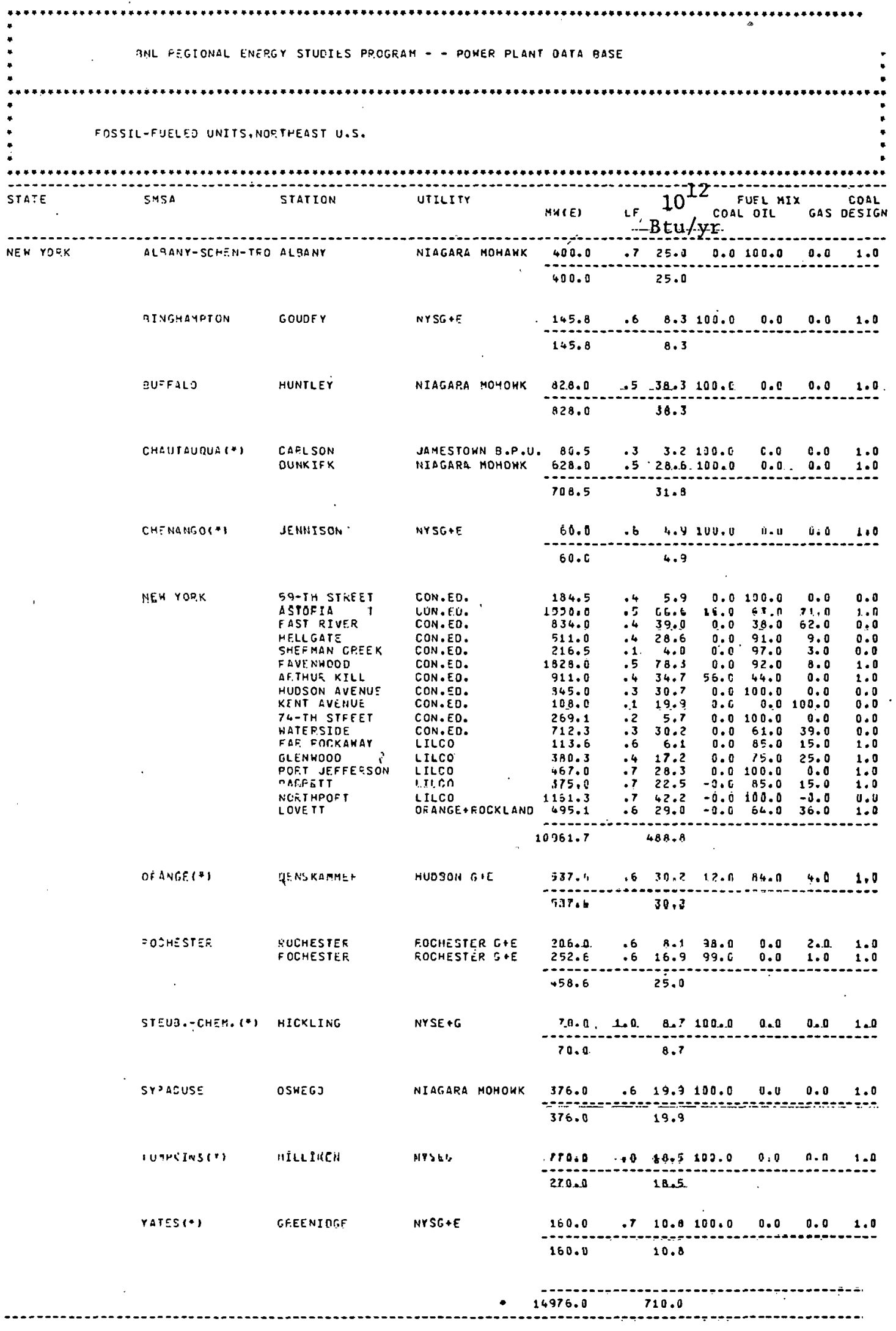




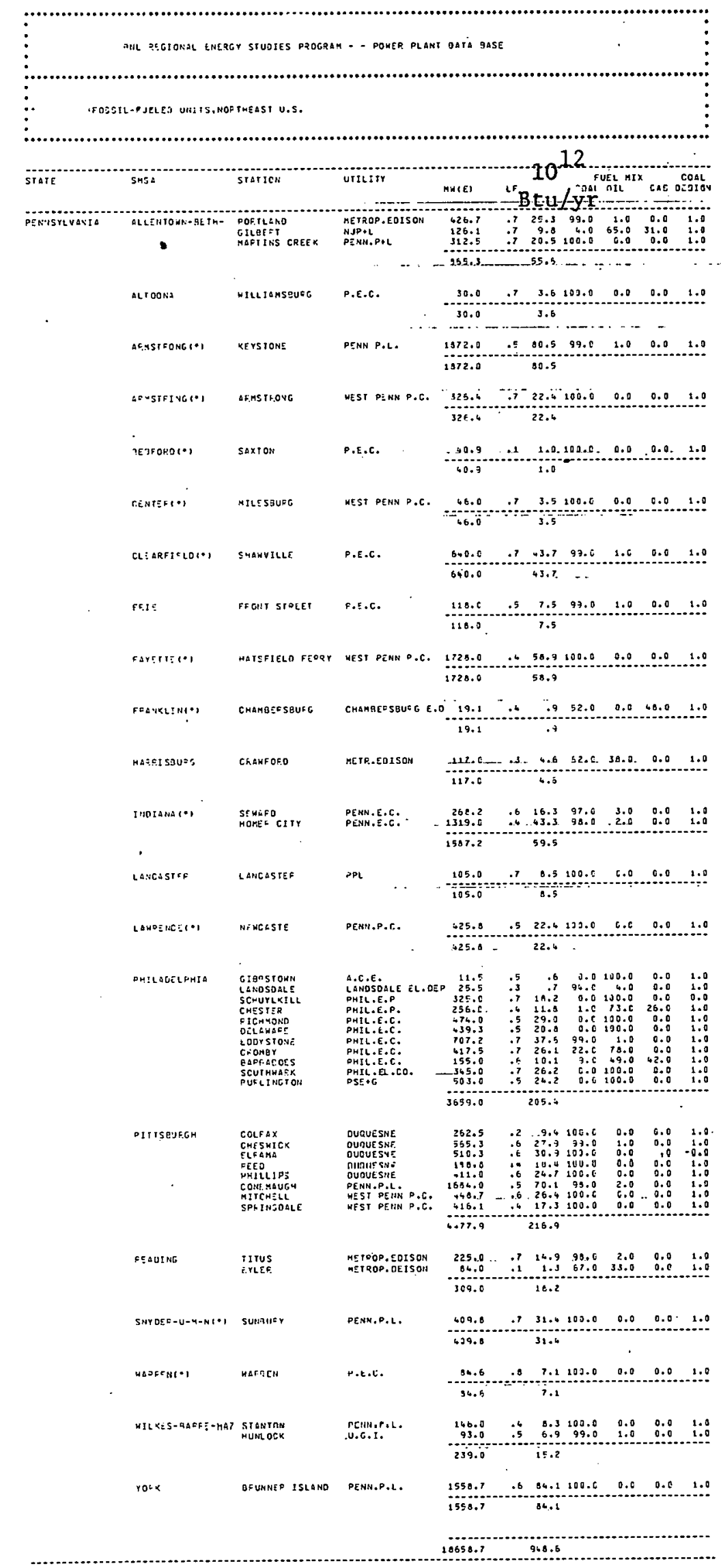



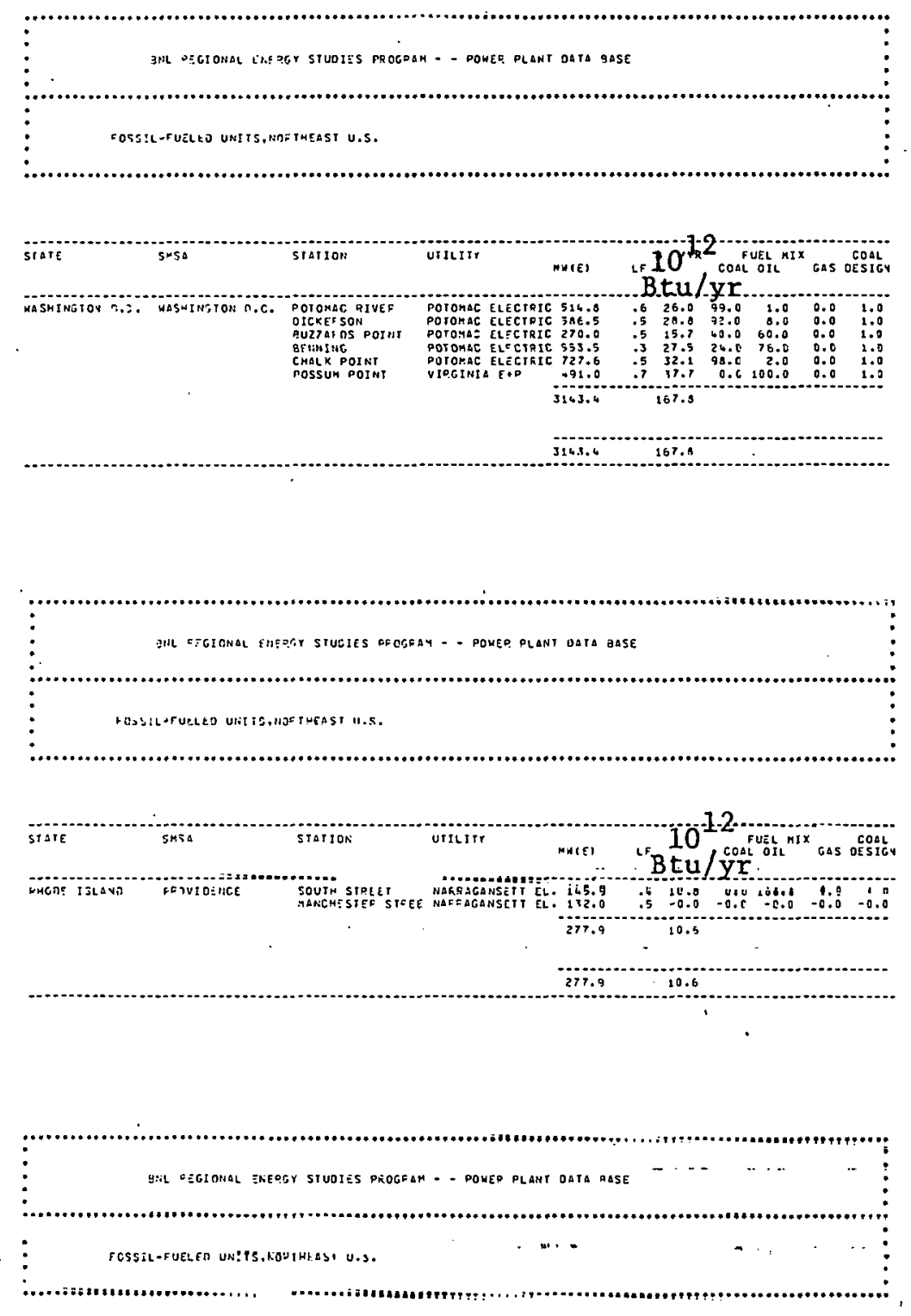

state


APPENDIX F: SUMMARY OF REFUSE-TO-ENERGY PROJECTS IN THE NORTHEAST*

\section{Project Description}

LOCATION :

EPA CONTACT:

PROJECT CONTACT:

PROJECT TYPE:

TONS/DAY :

CAPITAL COST:

METHOD OF FINANCING:

CONTRACTOR:
Baltimore, Maryland

David Sussman

Elliot Zulver

Project Director

pyrolysis plant

1801 Annapolis Road

Baltimore, Maryland 21330

(301) 396-3499

Pyrolysis

1000

\$16 million.

EPA grant - \$6 million.

state loan - $\$ 4$ million.

City funds - $\$ 6$ million.

Monsanto Enviro-Chem Systems, Inc.

\section{Project status}

Baltimore will own and operate a 1,000 ton per day solid waste pyrolysis plant developed by Monsanto Enviro-Chem Systems, Inc. The LANDGARD system will be designed and constructed by Monsanto under a turnkey contract with moneyback performance guarantee provisions. Monsanto is guaranteeing plant availability at 85 percent, particulate emissions to meet local, and Federal standards, and the residue putrescible content to be less than 0.2 percent.

The plant is being designed to handle mixed municipal solid waste, including tires and white goods. All incoming waste will be shredded to a 4-inch particle cizc and then cunveyed to a rotary pyrolysis kiln.

The pyrolysis gases leave the kiln and will then be combusted in an afterburner. The hot afterburner exhaust gases will pass through waste heat boilers that generate 200,000 pounds of steam per hour for sale to the Baltimore Gas and Electric Company. The steam will be used for downtown heating and cooling. Boiler exhaust gases will be scrubbed, dehumidified, and released to the atmosphere.

* Extracted from R.E. Hopper. "A Nationwide Survey of Resource Recovery Activities" U.S. Environmental Protection Agency, Report SW-142, Jan. 1975. 
Baltimore, Maryland

(continued)

Construction is complete and the plant is now in a shake-down phase.

The pyrolysis residue will be water quenched and ferrous metals will be separated. Water flotation and screening processes will separate the char residue, which must be landfilled ( $16^{\circ}$ tons, with 50 percent moisture, for every 100 tons of solid waste input), from a glassy aggregate fraction, which will be used as aggregate for city asphalt concrete street construction.

For additional information, see: Baltimore Demonstrates Gas Pyrolysis (SW-75d.i), David B. Sussman, U.S. Environmental Frotection Agenry, 1974. 


\section{oject Description}

LOCATION :

EPA CONTACT:

PROJECT CONTACT:

PROJECT TYPE:

TONS/DAY :

CAPITAL COST:

METHOD OF FINANCING:

CONTRACTOR:
Braintree, Massachusetts

Steven Levy

John Griffith, Superintendant Braintree Thermal Waste Reduction Center Ivory Street

Braintree, Massachusetts 02184

(617) 843-6209

Waterwall incineration.

240

$\$ 2.5$ million.

General obligation bonds.

Designed by Camp, Dresser and McKee.

\section{Project Status}

Plant has been operational since 1971, but until recently no steam was being sold. Community is now developing a market for steam. Recently, however, Braintree has begun to sell steam to the Weymouth Art and Leather Company . $(20,000-25,000 \mathrm{lbs} . / \mathrm{hr}$. or $400,000 \mathrm{lbs} . /$ day $)$ and is also negotiating with Michigan Abrasives, Inc. for an equal supply of steam. Initially, the plant's net operating costs were $\$ 30 /$ ton, but today the plant's net. operating costs are $\$ 5 /$ ton. The plant is presently processing 150-175 tons of waste per day on a 3 shift, 5 day per week basis. 
LOCATION :

EPA CONTACT :

PROJECT CONTACT:

PROJECT TYPE :

TONS/DAY :

CAPITAL COST:

METHOD OF FINANCING:

CONTRACTOR:
Bridgeport, Connecticut

Robert Randol

Richard P. Chase

CRRA; Connecticut Resources Recovery Authority 60 Washington street

Suite 1305

Hartford, connecticut 06106

(203) $549-6390$

Prepared waste as a supplementary fuel; materials recovery.

1800

$\$ 29$ million.

Connecticut Resources Recovery Authority

Garrett Research and Development

\section{Project status}

The system will process eighteen hundred tons of solid waste a day. The dry shredded fuel fraction will be sold to United Illuminating, a subsidiary of Northeast Utilities. United Illuminating is a new market for the fuel. Previously Connecticut Light and Power had been the designated user. Groundbreaking ceremonies were held on December 10 , 1974.

As of February 1; 1975 a final contract between The Connecticut Resources Recovery Aurhorlty and Garrett Research and Development had not been signed. However, a letter of intent to design, construct and operate a system was signed in September, 1974. Delays in the signing of the final contract stem from the reluctance of the contracting parties to assume different levels of risk.

Bridgeport will be the first system built in Connecticut. The interlocal agreement for delivery of solid waste (negotiated between CRRA and the communities) and the system's construction and operation contract (negotiated between CRRA and Garrett) will serve as models for future Implemeritations. 
oject Description

LOCATION :

EPA CONTACT:

PROJECT CONTACT :

PROJECT TYPE :

TONS/DAY :

CAPITAL COST:

METHOD OF FINANCING :

CONTRACTOR:
East Bridgewater, Massachusetts

Robert Holloway

John Reilly

CEA (Combustion Equipment Associates, Inc.)

555 Madison Avenue

New York, New York 10022

(212) $980-3700$

Prepared waste as a supplementary fuel.

600 (Two shifts)

Private capital.

CEA

\section{Project Status}

Plant shakedown started winter, 1973-74. Shakedown is continuing thru Sumer, 1974. No fuel product has been sold because no coal boilers are nearby. Plant is not operating except for experimentation because there is no market for the product.

In addition, CEA is basing future contracts on Eco-Fuel II, a chemically treated, pulverized solid fuel derived from waste. The East Bridgewater plant was designed to produce Eco-Fuel. I, the feed material to an Eco-Fuel II system. The East Bridgewater plant is to be modified in the future to produce Eco-Fuel II.

CEA plans Eco-Fuel II trial firings with fuel produced from a pilot plant at Weyerhaeuser Corp. (close to Brockton) and at Public Services Gas and Electric, Elizabeth, New Jersey. 


\section{Project Description}

LOCATION :

EPA CONTACT:

PROJECT CONTACT:

PROJECT TYPE:

TONS/DAY :

CAPITAL COST:

METHOD OF FINANCING:

CONTRACTOR:
Hackensack Meadowlands, New Jersey

Robert Holloway

George Casino

Chief Engineer

Hackensack Meadowlands Development Commission 1099 wall street, West

Lyndhurst, New Jersey 07071

(201) $935-3250$

Prepared waste as a supplementary fuel.

$\mathrm{N} / \mathrm{A}$

$\mathrm{N} / \mathrm{A}$

$N / A$

$\mathrm{N} / \mathrm{A}$

\section{Project status}

HMDC received 8 proposals in Fall 1973 as result of RFP. HMDC asked Stevens Institute and Fairleigh Dickinson University to review proposals. CEA was recommended.

No action was taken because of change in state administration.

HMDC has now contracted with First Boston Corporation, Sullivan \& Cromwell, and Hawkins, Delafield \& Wood to pursue negotiations with several of the original bidders to implement a fuel system.

Public Service Electric and Gas has expressed interest in waste fuel. PSEG signed a contract in August 1974 with CEA to burn 200 tons per day of ECO-Fuel II on a trial basis. CEA hopes to start preliminary tests with pellets within 2 months at PSEG and Weyerhaeuser (near CEA's East Bridgewater plant). Eco-Fuel II for the early burns will be produced by the pilot plant. Additional PSEG tests will be run in 1-2 years with fuel produced from a plant to be built in New Jersey. 


\section{ject Description}

LOCATION :

EPA CONTACT:

PROJECT CONTACT :

PROJECT TYPE :

TONS/DAY :

CAPITAL COST:

METHOD OF FINANCING:

CONTRACTOR:
Hempstead, New York

Alan Shilepsky

William Landman

Commissioner of Sanitation

1600 Merrick Road

Merrick, New York 11566

(516) 378-4210

Wet-pulping of waste for materials and energy recovery.

2000

$\$ 55$ million.

Exact form is undetermined until a contract is signed, but will probably be corporate revenue bonds.

Hempstead Resource Recovery Corp. (a subsidiary of Black Clawson Co.)

\section{Project status}

A contract was signed on December 12, 1974 between Hempstead and Hempstead Resource Recovery Corporation, a subsidiary of Black Clawson Corporation. The contract stipulates that the City "put or pay" to the recovery system at least 6000 tons of solid waste per week. The contract also requires the corporation to be capable of processing 11,000 tons per week with a maximum of 3 percent residue by volume. The system will recover ferrous, aluminum and glass (if economically feasible) and produce electricity. Revenues will be shared between the corporation and the City. Dump serve fees, depending on tonnages, will range between $\$ 14.05$ to $\$ 12.37$ per ton. 


\section{Project Description}

LOCATION :

EPA CONTACT:

PROJECT CONTACT:

PROJECT TYPE:

TONS/DAY :

CAPITAL COST:

METHOD OF FINANCING:

CONTRACTOR:
Housatonic Valley, Connecticut

Robert Randol

Robert Schulz

The Fourth Sink Management Group, Inc. P.O. Box 75

Kattskill Bay, New York 12844

(518) 656-9253

Prepared waste as a supplementary fuel; materials recovery.

1500

$\$ 35$ million.

CRRA funding requested (See State of Conn.)

CEA (Combustion Equipment Associates, Inc.)

\section{$\underline{\text { Project Status }}$}

Twenty two million dollar processing plant to be located in Newtown, Conn. to prepare Eco-Fuel II. Fuel will be shipped by rail to the Pierce power plant in Wallingford, Conn., where a $\$ 10$ million high-pressure steam generating facility will be designed and constructed by CEA.

CRRA limited to $\$ 100$ million funding through FY75. Therefore, with funding of New Britain and Bridgeport, CRRA cannot now fund entire Housatonic project. CRRA likely to fund just transfer station portion, with landfilling of waste until authority extended. 


\section{Project Description}

LOCATION :

EPA CONTACT:

PROJECT CONTACT:

PROJECT TYPE:

TONS/DAY :

CAPITAL COST:

METHOD OF FINANCING:

CONTRACTOR:
Monroe County, New York

Alan Shilepsky

Harold Christensen

Director of Solid Waste Department of Public Works 200 County office Building Rochester, New York 14614 (716) $454-7200$

Shredded fuel for supplementary burning in Rochester Gas and Electric Boilers.

2000

$\$ 25$ million, not including retrofitting and storage facilities.

Public improvement bonds plus at least $\$ 9$ million from the state.

Raytheon Service Corporation

\section{Project Status.}

Monroe County's request for proposals was prepared by the consulting engineering firm of Black, Crow and Eidsness and drew upon a market analysis atd feasibility study done by Black, Crow and Eidsness's parent company, Hercules. County officials have evaluated the proposals with the assistance of Black, Crow and Eidsness and have tentatively chosen Raytheon. A contract has been negotiated with Raytheon and the County legislature has authorized the County executive to execute the contract.

The proposed design involves two stages of shredding, air classification, and the recovery of ferrous and non-ferrous metals. 
Project Description

LOCATION :

EPA CONTACT :

PROJECT CONTACT :

PROJECT TYPE:

TONS/DAY :

CAPITAL CUS'I:

METHOD OF FINANCING:

CONTRACTOR:
Montgomery County, Maryland

Robert Holloway

F.K. Erickson

Office of Environmental Planning Montgomery County office Building Rockville, Maryland 20850

(301) 279-1316

Prepared waste as a supplementary fuel to be used in local utility boiler.

\section{0}

$\$ 16$ millinn.

General obligation bonds.

Pope, Evans, and Robbins Consulting Engineers.

\section{Project Statis}

Based on a feasibility study by Pope, Evans and Robbins, Consulting Engineers, New York, the County Executive recommended and the County Council approved a ten year solid waste management plan calling for a 1200 ton per day county-owned and operated resource recovery system, producing magnetic metals and shredded waste fuel to be used as a supplement to coal in Potomac Electric Power Company's (PEPCO) Dickerson, Maryland plant.

The \$16 million for the central processing facility has been approved in the county's budget and will probably be ublained by goneral obligation bonds. Funding for the $\$ 4$ million receiving and firing facility at Dickerson has not been yet arranged.

A site selection study identified five candidate sites. The site selection process began with hearings in September, and ended with the selection of a site in November, 1974. This site is now being acquired. Meanwhile, the county is also negotlatiny with PErCo as to the details of their contract. 'PEPCO's hoiler that will accept the waste fuel is a new 800 megawatt unit that is scheduled to go into operation in 1982 . 
LOCATION :

EPA CONTACT:

PROJECT CONTACT :

PROJECT TYPE :

TONS/DAY :

CAPITAL COST :

METHOD OF FINANCING:

CONTRACTOR:
Mt. Vernon, New York

Steven Levy

Seymour Lefkowitz

Intergovernmental Coordinator

City Hall

Mt. Vernon, New York

(914) 668-0737

Gas Pyrolysis

400

$N / A$

$\mathrm{N} / \mathrm{A}$

Union Carbide (Proposed)

\section{Project Status}

Mt. Vernon, as part of the Westchester County, New York plan, intends to build a 400 ton per day Union Carbide Purox system which will serve Mt. Vernon and the communities of North Pelham, Pelham and Pelham Manor. The gas produced will be used to generate electricity which will be sold to Consolidated Edison Company. 
LOCATION :

EPA CONTACT:

PROJECT CONTACT :

PROJECT TYPE :

TONS/DAY :

CAPITAL COST :

METIOD OF FINANR'INT:

CONTRACTOR:
New Britain, Connecticut

Robert Randol

Richard Chase

CRRA; Connecticut Resources $k$, overy Authority

60 Washington street

Suite 1305

Hartford, Connecticut 06106

(203) $549-6390$

Prepared waste as a supplementary fuel.

1800

$\$ 22$ million.

Revenue bonds.

CE $\Lambda$ (Combustion Equipment Associates, Inc.)

\section{Project status}

CEA proposes to produce Eco-Fuel II for the Wallingford power plant: (city owned). The waste fuel will reportedly be mixed with fuel oil and fired in combination into the existing boiler. ( $\mathrm{b}$ bility of Wallingford plant to accept large amounts of fuel unknown to EPA). A contract has not yet been signed.between any of the parties. After Bridgeport, New Britain will be the second project to be implemented by the Connecticut Resources Recovery Authority. 
LOCATION :

EPA CONTACT:

PROJECT CONTACT:

PROJECT TYPE:

TONS/DAY :

CAPITAL COST:

METHOD OF FINANCING :

CONTRACTOR:
New York, New York

David Sussman

Leonard F. O'Reilly

Director, Solid Waste Task Force

51 Chambers Street

New York, New York

(212) 566-0922

Shredded fuel.

1500

50 percent state funds.

50 percent City funds.

Consolidated Edison finances their plant modifications.

Horner \& Shifrin, Inc. for feasibility study.

\section{Project status}

City is finalizing contract with Horner \& Shifrin to design a 1500 ton per day shredded fuel plant in conjunction with Con Ed's Arthur Kill. plant, unit \#20. The plant will be simlar to the St. Louis demonstation plant. Construction will not begin until Con Ed is financially able to pay for the required modifications to its boilers. The plant will demonstrate the feasibility of shredded fuel in the New York City area.

Plans for a new 700 megawatt plant in the City that will burn 1600 tons per day are being formulated by the New York Power Authority. Implementation date for the plan is unknown. 
Project Description

LOCATION :

EPA CONTACT:

PROJECT CONTACT :

PROJECT TYPE :

TONS/DAY :

CAPITAL COST:

METHOD OF FINANCING:

CONTRACTOR:
Onondaga County, New York

Richard Hopper

Charles R. Stoffel

Federal Aid Representative

Onondaga County, New York

Box 23324

L'Enfant Piaza Station

Washington, D.C. 20024

(202) 554-2494

Waterwall incineration to produce steam for district heating and cooling.

1000

$\$ 21,503,900$

Municipal bonds; bond anticipation notes; State grant.

Carsles Curporation.

\section{Project Status}

Onondaga County owns and operates a mid-town district heating and cooling plant which supplies steam and chilled water to various rounty and City buildings in syracuse. A few blocks away is a district heating and cooling plant owned by Syrdcuse Univcroity serving many campus buildings, several hospitals, and a housing project. In May 1974, the County and University entered into a contrall with Carrior Corpniarion lu cunduet a foasibility study of the fossihilitics of converting the two plants to the use of municipal solid waste as a fuel.

To assist in the study, Carrier Corporation engaged the services of Roisson and Woese, Consulting Engineers; I.C. Thomasson \& Associates, Consulting Engineers; and Edward Joe Company, Mechanical Contractors. The completed study recommended that the existing county steam plant be plased out and that a new steam plant using solid waste as a fuel be built adjacent to the existing university steam plant site. 'he facility would have the capacity to incinerate most of the 1,200 tons of solid waste produced by Onondaga County's half milizon residents each day and would recover energy trom this waste in the form of steam. The existing university steam prlant would be retained as a standby unit, while the new plant would be designed to burn waste as delivered or to burn fuel that may be produced in the future by a pyrolysis system that would convert waste into gas or oil. The proposed plant will produce 270,000 pounde of steam per hour. 
LOCATION :

EPA CONTACT:

PROJECT CONTACT:

PROJECT TYPE :

TONS/DAY :

CAPITAL COST:

METHOD OF FINANCING:

CONTRACTOR:
Saugus, Massachusetts

Steven Levy

W.C. Stephens

Energy Systems Division

Wheelabrator-Frye, Inc.

299 Park Avenue

New York, New York 10017

Waterwall incineration.

1200

$\$ 30$ million.

Private.

RESCO

\section{Project Status}

RESCO (Refuse Energy Systems Company), a joint venture of De Matteo Construction Company and Wheelabrator-Frye, is constructing a waterwall incinerator in Saugus, Massachusetts. The steam generated will be sold to the General Electric Company plant at Lynn, Massachusetts, across the Saugus River. The plant's input refuse will come from some 16 communities north of Boston. The twenty year contract between RESCO and the communities provides for an initial disposal fee of $\$ 13$ per ton of solid waste. 
Project Description

LOCATION :

EPA CONTACT :

PROJECT CONTACT:

PROJECT TYPE:

TONS/DAY :

CAPITAL COST:

ME'I'HUU UF TINARCILG:

CONTRACTOR :
Washington, D.C.

Robert Holloway

Clark W. Hand

Environmental Planning

Metropolitan Washington Council

of Governments

1225 Connecticut Avenue, N.W.

Washington, D.C.

(202) 223-6800 Ext. 330.

Waste as fuel - probably to PriPCO. but looking for other fuel users.

$650-1300$

$\mathrm{N} / \mathrm{A}$

$N / A$

$N / A$

\section{Project Status}

Washington, D.C., and Fairfax, Arlington, and Alexandria counties in Northern Virginia are pursuing a regional approach to resource recovery. The project is being conducted by the Metropolitan Council of Governments $(C O G)$. The COG has contracted with the National Center for Resource Recovery to evaluate markets for recovered materials and to conduct a feasibility study of a facility for materials recovery and the proressing of solid waste into a supplementary fuel. The COG is also in the preliminary stages of negotiation with the Potomao and Electric Power Company to purchase the fuel.

The National Center for Resource Recovery's report was delivered to the COG in January. The District of Columbia plans to prepare a budget request for fiscal year 1976 funds to develop an engineering design and recommend equipment specifications. 
LOCATION :

EPA CONTACT:

PROJECT CONTACT:

PROJECT TYPE :

TONS/DAY :

CAPITAL COST:

METHOD OF FINANCING:

CONTRACTOR :
Westchester County, New York

Steven Levy

Robert Dennison

Commissioner of Public Works County office Building White Plains, New York

(914) 682-2537

County-wide.

400

\$105 million.

N/A

N/A

\section{Project Status}

County Plan calls for upgrading 3 or 4 existing incinerators and installing a Bureau of Mines incinerator recovery system, for building a thermal reduction facility at the County's Grasslands Reservation, for closing the croton Landfills and for building a 400 ton per day Union Carbide Purox System in Mt. Vernon. Under the plan, the County is divided into eight waste sheds for solid waste management and resource recovery, and the county assumes responsibility for solid waste disposal. 


\section{Project Description}

LOCATION :

EPA CONTACT:

PROJECT CONTACT :

PROJECT TYPE :

TONS/DAY :

CAPITAL COST:

METHOD OF FINANCING:

CONTRACTOR:
Wilmington, Delaware

Robert Holloway

Pasquale S. Canzano

Department of Natural Resources and Environmental Control

State of Delaware

Dover, Delaware 19901

(302) 678-4781

Preparea solid waste as a supplementary fuel to be used in oil fired utility boiler; sewage sludge will be processed; subsystems will include composting, pyrolysis, and materials recovery (ferrous, aluminum, glass).

500 (One shift).

$\$ 20$ million.

State general obligation bonds; EPA grant.

Full-service contract to be bid competitively with RFP.

\section{Project Status}

EPA awarded a $\$ 9$ million resource recovery demonstration grant to the State of Delaware in October, 1972. As a result of negotiations hetween EPA and Delawarc over conditions of the grant agreement, Delaware accepted EPA's recomendation not to compust the waste fuel to be burned in a Delmarva Power and Liylu Co. oil.nfirod boiler. Resolution of conditions and paper work required to amend project have delayed project about two years.

Delaware will apply for an EPA step III Water construction Grant for those facilities that handle sludye. Delaware plans to ask for $\$ 4-5$ million in EPA water funds.

Delaware hopes to develop an RFP package by early 1975. A contract should be signed by January, 1976 to design, construct, and operate the rduility. 
LOCATION :

EPA CONTACT:

PROJECT CONTACT:

PROJECT TYPE:

TONS/DAY :

CAPITAL COST:

METHOD OF FINANCING:

CONTRACTOR :
State of Connecticut

Robert Randol

Mr. Joseph L. Boren, Director

Solid Waste Management Programs

Department of Environmental Protection

state of connecticut

State office Building, Room 248

Hartford, Connecticut 06115

(203) 566-3672

Development of state authority.
Revenue bonds.

Garrett Research and Development Company (Bridgeport facility)

Combustion Equipment Associates

(Greater Hartford facility)

\section{Project status}

As a result of a comprehensive state plan developed by the connecticut Department of Environmental Protection, the state legislature created the connecticut Resources Recovery Authority (CRRA). The Authority is carrying out implementation of the plan, which calls for the construction by 1985 of 10 resource recovery facilities which will process 84 percent of the State's waste. CRRA has been given $\$ 250$ million bonding authority for facility construction. During formulation of the plan, the U.S. Environmental Protection Agency funded a study which gave the state an independent commentary on the proposed legislation, gave a framework for evaluation of proposed projects, and made recommendations for the organization and management of the Authority as well as on aspects of financing and system incentives. Contracts for the first two facilities have been awarded to Garrett Research and Development Company for a resource recovery plant in Bridgeport and to Combustion Equipment Associates for a plant in New Britain, which will serve several communities in the Greater Hartford area. Unique features of the Connecticut plan include:

Voluntary Participation. Communities are not recuired to utilize the services of the CRRA facilities, but instead may decide to do so on an economical basis.

Rate setting. There is no regulation of the rates charger to the communities. However, since the system is voluntary, CRRA is forced to be competitive with other means of disposal.

Private Sector Involvement. Since CRRA is limited to 30 employees. the private sector will be utilized for design, construction, and operation of facilities. 


\section{Project Description}

LOCATION :

EPA CONTACT:

PROJECT CONTACT:

PROJECT TYPE :

TONS/DAY :

CAPITAL COST:

METHOD OF FINANCING:

CONTRACTOR :
State of Maryland

Harry Butler

Cliff willey

Chief of Solid Waste Services

Maryland Environmental Services

Tawes State office Building

Annapolis, Maryland 21401

(301) 267-5666

State grant and loan program.

$N / A$

$\mathrm{N} / \mathrm{A}$

State appropriation.

$\mathrm{N} / \mathrm{A}$

\section{rrujecl 3tatua}

The Maryland Environmental Services (MES), can provide both grants and loans for resource recovery facilities. Four million dollars of the matching funds for the U.S. Environmental Protection Agency's $\$ 16$ million demonstration in Baltimore was provided by MES. In addition, MES is funding, in a joint venture with Baltimore county, the Baltimore County Solid Waste Disposal System and Reclamation Project. Phase I' of this project will consist of shredalng followed by magnetic separation. The ferrous fraction recovered will be sold to the detinning market. The remainder is to be landfilled. MES is spending $\$ 300,000$ on market and product development. Phase II of the project will corislst of xorovery of the fiber (either as fuel or fiberboard), glass and other heavy fraction as their markets develop. 


\section{Project Description}

LOCATION :

EPA CONTACT :

PROJECT CONTACT:

PROJECT TYPE :

TONS/DAY :

CAPITAL COST:

METHOD OF FINANCING:

CONTRACTOR:
Commonwealth of Massachusetts

Yvonne Garbe

Alden Cousins, Director Bureau of Solid Waste Disposal Massachusetts Department of Public Works 100 Nashua Street Boston, Massachusetts 02114 (617) 727-4293

Development of state plan.

$\mathrm{N} / \mathrm{A}$

$\mathrm{N} / \mathrm{A}$

$\mathrm{N} / \mathrm{A}$

$\mathrm{N} / \mathrm{A}$

\section{Project status}

The Commonwealth of Massachusetts is implementing a state-wide resource recovery plan. The plan features a system of privately financed, privately owned, state controlled resource recovery. facilities. The State has issued a "Request for Proposals" as a first step towards implementing a resource recovery facility in the Greater Lawrence area.

A bidders conference was held on January 11, 1975 with proposals to be returned for review by March 18, 1975. 
Project Description

LOCATION :

EPA CONTACT:

PROJECT CONTACT:

PROJECT TYPE :

TONS/DAY :

CAPITAL COST:

METHOD OF FINANCING:

CONTRACTOR:
State of New York

Harry Butler

David Mafrizi, Director

Bureau of Resource Recovery

Division of Solid Waste Management

New York State Department of Environmental Conservation

50 Wolf Road

Albany, New York 12201

(518) 457-3199

State grant program.

$\mathrm{N} / \mathrm{A}$

$\$ 175$ million for solid waste disposal and resource recovery grants to local government.

General obligation bond.

$\mathrm{N} / \mathrm{A}$

\section{Project status}

New York State voters have approved a $\$ 1.1$ billion Environmental Bond, which includes $\$ 175$ million for solid waste disposal and resource recovery facilities. The regulations provide up to 25 percent state funding for disposal projects and up to 50 percent for resource recovery projects, thus increasing the incentive for resource recnvery. In addition, the regulations provide that to be eligible for state assistance, a pxoject must be consistent with a comprehensive solid waste management plan. Comprehensive plans must: (1) assure that all municipalities within a region will be served by a solid waste recovery and management system; (2) provide for intermunicipal cooperation; (3) define solid waste collection service areas and the type of service to be provided; (4) utilize modern technology to best meet local needs and optimize opportunities for resource recovery; and (5) provide for phased implementation of proposed systems to meet short range and long range needs. To date, \$116 million has been set aside for specific resource recovery projects. Actual grant awards will be mado to the speciftc colmunitieg upon state approval of the contractor's bic price for a facility. 


\section{Project Description}

LOCATION :

EPA CONTACT :

PROJECT CONTACT :

PROJECT TYPE :

TONS/DAY :

CAPITAL COST:

METHOD OF FINANCING:

CONTRACTOR
Commonwealth of Pennsylvania

Richard Hopper

William C. Bucciarelli, Director Division of Solid Waste Management Department of Environmental Resources 8th Floor Fulton Building P.O. Box 2063

Harrisburg, Pennsylvania 17120 (717) 787-7381

State loan program.

$\mathrm{N} / \mathrm{A}$

$\mathrm{N} / \mathrm{A}$

$\mathrm{N} / \mathrm{A}$

$N / A$

\section{Project Status}

In 1974 the Pennsylvania State Legislature enacted the Pennsylvania Solid Waste Resource Recovery Development Act creating a state loan program for local resource recovery projects. Requirements of the Act are that in reviewing applications for loans, the Department of Environmental Resources shall: (I) consider the amounts of polluting substances treated and/or eliminated; (2) the overall environmental benefits to be accrued as a result of the projects; (3) the amount of populations served; and (4) the extent of resource recovery to be included. Furthermore, the law requires that no loan shall be made to any local government which is not a part of a department approved local solid waste management plan. Twenty million dollars was appropriated for the purposes of the Act. At present, the Department of Environmental Resources is drafting rules and regulations to implement the loan program. 


\section{Project Description}

LOCATION :

EPA CONTACT:

PROJECT CONTACT :

PROJECT TYPE:

TONS/DAY :

CAPITAL COST:

METHOD OF FINANCING:

CONTRACTOR :
State of Rhode Island

David Sussman

John Quinn, Jr., Chief

Division of Solid Waste Management

State Health Department

204 Health Building

Davis street

Providence, Rhode Island 02908

(401) 277-2808

Development of state plan.

$\mathrm{N} / \mathrm{A}$

$\mathrm{N} / \mathrm{A}$

$\mathrm{N} / \mathrm{A}$

$\mathrm{N} / \mathrm{A}$

\section{Project status}

The Rhode Island legislature has created the Rhode Island Solid Waste Management Corporation. The legislation which created the Corporation is a result of the State Solid Waste Management Plan and is modeled after the Connecticut Resource Recovery legislation. Environmental. Protection Agency, through a grant to Rhode Island, assisted in the preparation of the state Plan.

As outlined. in the legislation, details of the state program are:

(1) lhe corpusation will propare and implement a functional lcvel plan for an integrintod ctaţewide system of solid waste management facilities;

(2) Municipal participation in the statewide system of solid waste management facilities that will be developed by the corporation will be on a voluntary basis.

(3) The coxporattun will malce ite waste management facilities available under contract to any municipality, institution, or person at reasonablc fees estahli.shed by the corporation; and, 
State of Rhode Island

(continued)

(4) Any revenues received by the corporation shall be used by said corporation to provide the financial support that is required to maintain financial solvency.

Since a bond referendum to fund the corporation failed in last year's elections, the state is presently exploring other alternatives for providing the necessary start-up funding for the corporation.

Although there is no funding for the corporation, the Advisory Board has been appointed and is operating, with the expectation that staff will be hired this Spring. 
Project Description

LOCATION :

EPA CONTACT :

PROJECT CONTACT:

PROJECT TYPE :

TONS/DAY :

CAPITAL COST:

METHOD OF FINANCING:

CONTRACTOR:
State of Vermont

Yvonne Garbe

Richard Valentinetti

Air \& Solid Waste Programs

Protection Division

Agency of Environmental Conservation P.O. Box 489

Montpelier, Vermont 05602

(802) 828-3395

Development of state plan.

$\mathrm{N} / \mathrm{A}$

$N / A$

$\mathrm{N} / \mathrm{A}$

$\mathrm{N} / \mathrm{A}$

\section{Project Status}

The state solid waste plan calls for inandatory separation of wastes by the householder and for the construction of four regional resource recovery facilities. The proposed legislation to put this plan into effect failed to pass in 1973, and again in 1974. The state is currently drafting more general legislation to be introduced in the legislature in 1975 that would respond to criticisms of previous legislation by being less specific, and giving greater flexibility to the Agency of Environmental Conservation to develop the details. 


\section{APPENDIX G: BIBLIOGRAPHY}

\section{General References}

Midwest Research Institute, "Resource Recovery - The State of Technolcgy Report to the Council on Environmental Quality", February, 1973.

A.D. Little Inc., "A Systems Evaluation of Alternative Statewide Resource Recovery Options for the Disposal of Municipal Solid Waste", Report to the Massachusetts Department of Public Works, December, 1973.

L.L. Anderson, "Energy Potential from Organic Wastes: Review of the Quantities and Sources", U.S. Bureau of Mines, Information Circular 8549, 1972 (Published by NTIS, PB 211 249).

S. J. Levy, "Markets and Technology for Recovering Energy from Solid Waste", U.S. EPA Report SW-130, 1974.

J. Abert, H. Alter, and J. Bernheisel, "The Economics of Resource Recovery from Municipal Solid Waste", Science, 183, 1052-1058 (1974).

R. E. Hopper, "A Nationwide Survey of Resource Recovery Activities", U.S. Environmental Protection Agency, Publication-SW-142, January, 1975 .

C. J. Huang and C. Dalton, "Energy Recovery from Solid Waste", University of Houston, Texas, April, 1975, (Published by NTIS N75-25292).

J. Payne "Energy Recovery from Refuse -State-of-the-Art" Journal, Environmental Engineering Division, ASCE, $102, \mathrm{EE} 2$ p. 281 (Apr.1976) 


\section{Direct Firing}

H.W. Schulz, "Cost/Benefits of Solid Waste Reuse, Environmental Science \& Technology, Vol. 9, No. 5, p. 423, (May, 1975).

Horner \& Shifrin, Solid Waste as a Fuel for Power Plants", U.S. EPA, 1973 (Publis hed by NTIS, PB 220 316).

R. M. Roberts and R. C. Hansen, "Combined Firing Systems for Specific Metropolitan Areas", U.S. Environmental Protection Agency, November 1971 (Published by NTIS, Report PB 207 701).

Envirogenics Company, "Systems Evaluation of Refuse as a Low Sulfirr Fuel, Volume 1", U.S. Environmental Protection Agency, November 1971 (Published by NIIS PB 209 271).

L.J. Shannon et al, "St. Louis/Union Electric Refuse Firing Domonstration Air Pollution Test Report", Report by Midwest Research instilule to EPÃ, Augirst. 1974 (Fublished by NTIS. PB 237 630), p. 40 .

E.K. Dille and D.L. Klumb, "Recycling Solid waste for Utility Fuel and Recovery of Other Resources", Proceedings, 1973 frontiers of Power Technology, Oklahoma State University.

Gordian Associates, Inc., "Where the Boilers Are: A Survey of Electric Utility Boilers with Potential Capacity for Burning Solid Waste as a Fuel", Report to the U.S. Environmental Protection Agency, 1974 (Published by NTIS, IB 239 392.). 


\section{Steam Generation}

"Refuse to Energy Plant Uses First Von Roll Incinerators in U.S.", Environmental Science \& Technology, Vol. 8, NO. 8, P. 693 (August 1974).

"Local Trash Cuts Downtown Fuel Bills", Environmental Science and Technology, september 1972, p. 780 .

Metcalf \& Eddy, Inc., "Generation of Steam from solid Wastes", U.S. Environmental Protection Agency, 1972 (Published by NTIS PB 214 166).

\section{Pyrolysis}

C.S. Finney and D.E. Garrett, "The Flash Pyrolysis of Solid Wastes", Energy Sources, Vol. 1, No. 1, p. 295 (1974).

B. Baum and C.H. Parker, "Solid Waste Disposal: Vol. 2, Reuse/ Recycle and Pyrolysis", Ann Arbor Science Publishers, Inc., Ann Arbor, Michigan, 1974.

H.W. Schulz, "Cost/Benefits of Solid Waste Reuse", Environmental Science. and Technology, Vol. 9, No. 5, p. 423 (May 1975).

T.H. Crane et at. "Production of Gaseous Fuel by Pyrolysis of Municipal Solid Waste" (NTIS, N75-24105/GWP) 1975.

Hamilton Standard Division, United Aircraft "Pyrolysis System Evaluation Study" (NTIS, N75 18722/GWP), 1974. 


\section{Bioconversion}

J. Pfeffer, "Reclamation of Energy from Organic Waste", U.S. Environmental Protection Agency, 1974 (Published by NTIS PB 231 176).

J. McFarland et al, "Comprehensive Studies of Solid Wastes Management, Final Report", University of California at Berkeley, Berkeley, Calif:, 1972, Report No. SERL 72-3.

P. Meier, et al, "Wet Systems for Residential Refuse Collection: A Case Study of Springfield, Mass", U.S. Environmental Protection Agency, March 1974 (Puọlished by NTIS PB 234 499).

P. Meier, J. Kuhner, and C. Martel, "A Preliminary Assessment for Resloentlal Refuse Collection", U.S. Fnvironmental Protection Agency, March 1974 (Published by N'IS PB 234 496).

Proceedings of the Bioconversion Energy Research Conference, Institute for Man and Environment, University of Massachusetts, Amherst, Mass., 1973.

C. Bissele, et al, "Urban Trash Methanation - Background for a Proof of Concept Experiment", MITRE Technical Report MTR 6856, McLean, VA 22101, February 1975.

\section{Other Cónversion Options}

H.F. Feldman, "Pipeline Gas from Solid Wastes", In A.I.Ch.E. Symposium Series, Vol. 68, 1972, "Chemical Engineeririg Applications in Solid Waste Treatment", No. 122, p. 125.

A.L. Compere \& W.L. Griffith "Anaerobic Mechanisms for Degradation of Cellulose" ORNL-5056, Oak Ridge National Laboratory, Oak Ridge, Tennessee, 1975 .

R.D. Faqan et al. "Kinetics of Acid Hydrolysis of Cellulose found in Paper Refuse" Environmental Science \& 'l'echnoluyy, Vul. :, No. 6 (June 1971).

A. Porteus "An Assessment of Énergy Recuvery Methods nppliadble to Domestic Refuse Disposal" Resources Policy, Vol. 1, No 5 p. 284 , (September 1975). 


\section{THE BROOKHAVEN NATIONAL LABORATORY} REGIONAL ENERGY STUDIES PROGRAM

The Brookhaven National Laboratory Regional Energy Studies Program is part of a national effort supported by the U.S. Energy Research and Development Administration (ERDA) to create an energy assessment capability which is sensitive to regional conditions, perceptions, and impacts. Within ERDA, this program is supported by the Division of Biomedical and Environmental Research and includes, in addition to a concern for health and environmental impacts of energy systems. analysis of the complex trade-offs between economics, environmental quality, technical considerations, national security, social impacts, and institutional questions. The Brookhaven Program focuses on the Northeast, including the New England states, New York, Pennsylvania, New Jersey. Maryland, Delaware, and the District of Columbia. The content of the program is determined through an identification of the major energy planning issues of the region and in consultation with state and regional agencies. A major component of the program in 1976 is the Northeast Energy Perspectives Study which examines the implications of alternative energy supply-demand possibilities for the region. 